\title{
Regulación de la protección de los trabajadores de la salud para la prevención del riesgo biológico
}

José Ma. SERNA DE LA GARZA

Coordinador

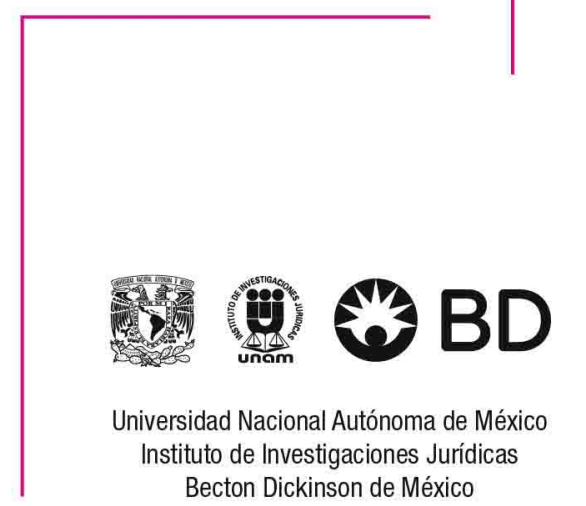




\author{
REGULACIÓN DE LA PROTEGGIÓN \\ DE LOS TRABAJADORES DE LA SALUD \\ PARA LA PREVENCIÓN DEL RIESGO BIOLÓGICO
}


INSTITUTO DE INVESTIGACIONES JURÍDICAS

Serie Estudios JuRídicos, núm. 324

\title{
COORDINACIÓN EDITORIAL
}

\author{
Lic. Raúl Márquez Romero \\ Secretario Técnico
}

Lic. Wendy Vanesa Rocha Cacho

Jefa del Departamento de Publicaciones

Edna María López García

Cuidado de la edición y formación en computadora

Carlos Martín Aguilera Ortíz

Elaboración de portada 


\section{REGULACIÓN DE LA PROTEGGIÓN DE LOS TRABAJADORES \\ DE LA SALUD PARA LA PREVENGIÓN DEL RIESGO BIOLÓGICO}

José MA. SERnA DE LA GARZA

Coordinador
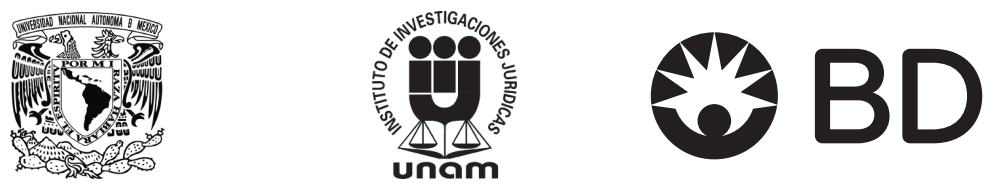

UNIVERSIDAD NACIONAL AUTÓNOMA DE MÉXICO INSTITUTO DE INVESTIGACIONES JURÍDICAS BECTON DICKINSON DE MÉXICO

MÉXICO, 2018 
Primera edición: 30 de julio de 2018

DR (C) 2018. Universidad Nacional Autónoma de México

INSTITUTO DE INVESTIGACIONES JURÍDICAS

Circuito Maestro Mario de la Cueva s/n Ciudad de la Investigación en Humanidades

Ciudad Universitaria, 04510 Ciudad de México

DR (C) 2018. BeGTon Dickinson de MéXiCo

Monte Pelvoux 111, piso 9, Lomas de Chapultepec

Miguel Hidalgo, 11000 Ciudad de México

Impreso y hecho en México

ISBN 978-607-30-0519-7 


\section{GONTENIDO}

Presentación ....................... VII José Ma. SERna DE LA GarZA

Regulación de la protección de los trabajadores de la salud.

Fernando CANo VALLE

El modelo europeo para la regulación del manejo del riesgo biológico ...................... Simon LINDSAY

Regulación basada en riesgos para prevenir lesiones biológicas del trabajador de la salud en México ......... María de Jesús Medina ARELlano

El impacto de la regulación del manejo del riesgo biológico en los Estados Unidos de América . . . . . . . . . . . . . Amber MiTCHELL

Protección de los trabajadores de la salud........... Alfredo SÁnchez CASTAÑEDA

Aspectos clínicos y normativos de la regulación de la protección de los trabajadores de la salud ............ 85 Edgar Enrique SEVILLA REYES 
La importancia de la protección del derecho a la salud de los trabajadores del sector salud . . . . . . . . . . 93 Alberto Abad SuÁrez Ávila

Regulación de la protección de los trabajadores de la salud

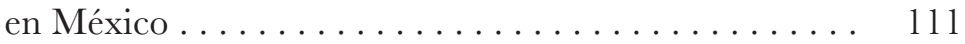
Roxana Trejo GONZÁlEz 
Este libro forma parte del acervo de la Biblioteca Jurídica Virtual del Instituto de Investigaciones Jurídicas de la UNAM

\section{PRESENTACIÓN}

Los ensayos contenidos en el presente libro tienen como común denominador una realidad que podemos y debemos mejorar: México tiene un enorme rezago en cuanto a la regulación relativa a la evaluación, prevención y gestión del riesgo biológico. Como quedará claro a partir de la lectura de las contribuciones de los destacados especialistas nacionales y extranjeros que participan en esta obra, una mejor regulación de la protección de los trabajadores de la salud beneficiaría por igual a éstos, a los pacientes y a todos aquellos que por alguna razón tienen contacto con el material que se utiliza y posteriormente sale de las instituciones de salud. Aunque, en realidad, el riesgo de un manejo inadecuado de este material se proyecta hacia la sociedad entera, de ahí la importancia de diseñar y construir un modelo regulatorio que tome en cuenta todas las contingencias posibles que puedan poner en riesgo la seguridad de los pacientes y de los trabajadores que los atienden.

Quien lea esta obra se dará cuenta, entre otras cosas, que es necesario generar una base de datos nacional, amplia, detallada e integral, sobre los riesgos biológicos a que están expuestos los trabajadores de la salud en México. Otros países, como los Estados Unidos de América y el Reino Unido, cuentan con datos duros y estadísticas que permiten diseñar estrategias de seguridad eficaces y efectivas.

Asimismo, sería conveniente pensar en la posibilidad de redactar y aprobar una regulación en la materia - que siga los estándares internacionales -, bajo la tutela de la autoridad sanitaria y/o laboral, que dé seguridad a los trabajadores de la salud. Vinculada con esta propuesta podría también ponderarse la posibilidad y conveniencia de crear un sistema nacional que termine con la dispersión, la fragmentación y la discrecionalidad 
Este libro forma parte del acervo de la Biblioteca Jurídica Virtual del Instituto de Investigaciones Jurídicas de la UNAM

en la evaluación, prevención y gestión del riesgo biológico, así como en la atención a quienes sufren daños por estar expuestos a dicho riesgo.

Además, es claro que las mismas instituciones del sector salud, públicas y privadas, deben generar sus guías de práctica clínica para la atención del riesgo biológico - de igual modo, siguiendo estándares internacionalmente aceptados en la materia-. Adicionalmente, se requiere, por un lado, tener criterios generales para regular el abastecimiento, uso y disposición del material médico de los hospitales; por otro, las instituciones hospitalarias deben contar con el equipo e instrumental médico adecuados que garanticen la seguridad a los trabajadores de la salud antes, durante y después de su utilización.

Se requieren normas y directrices nacionales armonizadas para la construcción de hospitales, que definan criterios de seguridad para los trabajadores de la salud y los pacientes en sus diversos espacios. Es preciso introducir el enfoque de la seguridad y prevención del riesgo biológico en la arquitectura y en la ingeniería de los hospitales de México.

Y por añadidura, actualizar el esquema regulatorio de la protección de los trabajadores de la salud en nuestro país precisa de una definición legal clara de derechos y deberes de todos los actores del sector salud expuestos a riesgo biológico: empleadores, empleados, residentes, prestadores de servicios y contratistas que interactúan con las instituciones hospitalarias y sanitarias.

Lo anterior incluye la necesidad de pensar en la posibilidad de que la Ley Federal del Trabajo regule, en el apartado "Trabajos especiales", las especificidades de los trabajadores de la salud - particularmente en lo que tiene que ver con el riesgo biológico y la seguridad de los trabajadores-, e implica, también, la revisión de los mecanismos jurídicos para exigir compensación por daños sufridos por los trabajadores de la salud cuando los hospitales incumplen con sus deberes de seguridad en el trabajo. Incluso se podría pensar en la posibilidad de que en México existan disposiciones en ley que aborden de modo específico la seguridad 
Este libro forma parte del acervo de la Biblioteca Jurídica Virtual del Instituto de Investigaciones Jurídicas de la UNAM

y prevención de accidentes con instrumental médico punzocortante, tal y como existe en muchos otros países.

A partir de la lectura de este libro se podrá constatar que es necesario educar y capacitar para generar cambio en las conductas y poder así terminar con prácticas inseguras y de riesgo. Igualmente, es imprescindible pensar cómo revertir el sesgo contrario a la mujer del actual esquema de protección de los trabajadores de la salud.

La agenda de discusión y de cambio normativo e institucional es muy amplia. Estas páginas pretenden ser una contribución para iniciar un debate, una conversación constructiva con todos los actores interesados en mejorar el marco regulatorio de la protección de los trabajadores de la salud en México.

Por último, agradecemos a la empresa Becton Dickinson de México S. A. de C. V., el invaluable apoyo dado para la organización de un seminario internacional sobre la regulación de la protección de los trabajadores de la salud, así como para la publicación del presente libro.

José Ma. SERnA DE LA GARZA 
Este libro forma parte del acervo de la Biblioteca Jurídica Virtual del Instituto de Investigaciones Jurídicas de la UNAM

\section{REGULACIÓN DE LA PROTEGGIÓN DE LOS TRABAJADORES DE LA SALUD}

Fernando CANO VALLE*

Sumario: I. Introducción. II. Derecho a la saludy derecho laboral. III. Conclusión: la perspectiva de género.

\section{INTRODUCCIÓN}

La Comisión Económica Europea, en el año de 1993, publicó el decreto de creación de la Agencia Europea para la Seguridad y la Salud en el Trabajo, que emite directivas para su aplicación en los países miembros y las implementen en sus regulaciones. A su vez, el Congreso de los Estados Unidos de América expidió un decreto en 1970 a través del cual se crea la Ley de Seguridad y Salud en el Trabajo.

Ahora bien, la palabra riesgo tiene diferentes acepciones: exposición, peligro, contingencia e inseguridad, entre otras. Y la inseguridad en la vida hospitalaria existe en general, pero sobre todo en los servicios de urgencias como resultado del uso de materiales cortantes y punzantes y el contacto con pacientes no diagnosticados.

Los agentes biológicos poseen un riesgo elevado de transmisión. La exposición a patógenos son más frecuentes entre el

* Investigador en el Instituto de Investigaciones Jurídicas de la UNAM. Exdirector de la Facultad de Medicina de la UNAM. 
Este libro forma parte del acervo de la Biblioteca Jurídica Virtual del Instituto de Investigaciones Jurídicas de la UNAM

personal eventual que entre el personal de base, ya que el primero es menos experto en los procedimientos. Asimismo, la mayoría de los riesgos emergentes están relacionados con epidemias mundiales, la pandemia del síndrome respiratorio agudo severo (SARS), influenza, ébola, fiebre amarilla, tuberculosis y hepatitis son agentes frecuentes en el escenario.

El riesgo en algunas regiones - tal es el caso típico del SARS - se da en las áreas de limpieza y de desechos biológicos en las instalaciones sanitarias. Así, pueden producirse situaciones de exposición complejas que involucran virus o mohos. Los riesgos biológicos nuevos pueden ir en aumento y las medidas en relación con la seguridad en el trabajo requieren de medios de control local y colectivo. Un ejemplo de medidas a analizar es el uso de los guantes de látex, ya que no usarlos puede constituir un importante problema de salud por su relevancia y por la gravedad del fenómeno alérgico.

En México, actualmente existen diversas disposiciones legales, reglamentarias y normativas dispersas en diversos ordenamientos, sin que exista una sola ley - como en otros países - que dé pauta a un esquema nacional único.

La Constitución Política de los Estados Unidos Mexicanos, artículo 123, apartado A, fracción XV, señala el requerimiento de cumplir con las disposiciones en seguridad e higiene en el trabajo, por lo patrones y trabajadores, con el fin de tener centros seguros e higiénicos, garantizar la salud y la vida de los trabajadores y de la mujer en estado de gestación con el propósito de garantizar la viabilidad de éste. La Ley Federal del Trabajo, reglamentaria de dicho artículo, incluye la materia de riesgos de trabajo en el título IX y conceptos diversos de seguridad e higiene, o de salud y seguridad en el trabajo, entre otros.

No obstante, Juan Antonio Legaspi ha señalado reiteradamente la necesidad de un sistema nacional que integre todo lo disperso mediante la expedición de un código general bajo la tutela de la autoridad laboral. Este código vendría a unificar conceptos, términos, atribuciones y responsabilidades tanto del 
Este libro forma parte del acervo de la Biblioteca Jurídica Virtual del Instituto de Investigaciones Jurídicas de la UNAM

gobierno como de patrones y trabajadores para facilitar su comprensión, difusión e implementación en los centros de trabajo. ${ }^{1}$

Esta opinión es secundada por otros especialistas e investigadores en el campo de la salud en el trabajo, quienes también opinan que promovería las obligaciones que México ha contraído a través de la firma de convenios con la Organización Internacional del Trabajo, cuyos tratados internacionales, de acuerdo a la Constitución, adquieren el carácter de ley suprema de la Nación.

TABLA I. Disposiciones de la Ley Federal del Trabajo relativas a seguridad e higiene

\begin{tabular}{|c|c|}
\hline $475 \mathrm{Bis}$ & $\begin{array}{l}\text { Seguridad e higiene de la prevención de riesgos } \\
\text { en el trabajo }\end{array}$ \\
\hline 490, fracc. I & Seguridad, salud y medio ambiente del trabajo \\
\hline 509 & Comisiones de seguridad e higiene \\
\hline 511, fracc. III & Prevención de riesgos de higiene y salubridad \\
\hline $512 \mathrm{~A}$ & $\begin{array}{c}\text { Materia de seguridad, salud y medio ambiente de } \\
\text { trabajo; Comisión Consultiva Nacional de Seguridad } \\
\text { y Salud en el Trabajo }\end{array}$ \\
\hline $512 \mathrm{~B}$ & $\begin{array}{l}\text { Comisión Consultiva Estatal de Seguridad y Salud } \\
\text { en el Trabajo }\end{array}$ \\
\hline $512 \mathrm{~F}$ & $\begin{array}{l}\text { Normas de seguridad, salud y medio ambiente } \\
\text { de trabajo }\end{array}$ \\
\hline $512 \mathrm{G}$ & Seguridad y salud \\
\hline 541 , fracc. I & Riesgos de trabajo, seguridad e higiene \\
\hline
\end{tabular}

Un sistema nacional a través de un solo ordenamiento legal, como sería el código federal, deberá prever lo necesario para las investigaciones en el campo de la seguridad y la salud en el tra-

1 Legaspi Velasco, Juan Antonio, "Derecho y salud en el trabajo. Hacia un sistema nacional de seguridad y salud en el trabajo", disponible en: http://wrwe. anmm.org.mx/actas2015/SO22ABRIL2015/5-fUAN-ANTONIO-LEGASPI.pdf. 
Este libro forma parte del acervo de la Biblioteca Jurídica Virtual del Instituto de Investigaciones Jurídicas de la UNAM

bajo, ausentes hoy, en donde existe un campo muy amplio en las materias, especialmente en lo concerniente a la salud de los trabajadores expuestos a múltiples agentes externos, químicos, físicos, biológicos, psicosociales, ergonómicos y organizacionales. Hoy día, la literatura médica nos da a conocer el importante aumento de defunciones y de morbilidad por dichos agentes factores en el cáncer, el estrés, los problemas cardiovasculares, los disruptores endócrinos, etcétera, teniendo un vasto campo a ser revisado por parte de las instituciones de salud en temas tales como: a) La naturaleza de los agentes físicos, químicos y biológicos presentes en el ambiente de trabajo y sus correspondientes intensidades, concentraciones o niveles de presencia, y b) Las características generales de los locales, instalaciones, equipos, productos y demás útiles existentes en el centro de trabajo.

\section{DERECHO A LA SALUD Y DERECHO LABORAL}

Se debe considerar la conformación de un área exclusiva de salud en el trabajo para el personal del ámbito de la salud, primer contacto o alta especialidad, para cumplir con los postulados constitucionales, internacionales y legislativos e incluir a todo el personal que mantiene vida hospitalaria o empresas afines.

Como se aprecia, el respeto del derecho a la protección de la salud posee un carácter universal, lo cual significa que debe resguardarse en todos los ámbitos de la existencia humana. Por lo que respecta a las relaciones laborales, su resguardo adquiere la mayor relevancia, puesto que tanto el derecho a la salud como el derecho al trabajo forman parte de los derechos sociales, cuya trascendencia radica en salvaguardar los intereses de toda la sociedad, especialmente de los grupos que se encuentran en desventaja por su condición económica y social desfavorable.

Los rezagos existentes en México en materia protección a la salud al interior de las empresas son variados, ya que la capacidad de las autoridades del trabajo para afrontar contingencias sanitarias es un asunto profundamente descuidado desde hace bastante 
Este libro forma parte del acervo de la Biblioteca Jurídica Virtual del Instituto de Investigaciones Jurídicas de la UNAM

tiempo. Por ejemplo, sabido es que las juntas de conciliación y arbitraje eran dependencias sumamente limitadas en cuanto a los recursos profesionales que tienen para impartir justicia y hacer valer las normas jurídicas en caso de que los trabajadores de las empresas desarrollen cualquier tipo de enfermedad contraída en el ejercicio de sus labores, particularmente en caso de contingencias sanitarias; la inspección del trabajo - tal y como opera hoy en día - no es más que un instrumento favorable a la simulación, puesto que sus atribuciones se concretan simplemente a emitir sanciones administrativas en contra de los patrones que incumplen las normas sanitarias y de seguridad laboral.

Por otra parte, y por lo que corresponde al derecho laboral mexicano en su parte sustantiva, la ley omite protección a los derechos de los médicos internos de pregrado, quienes por la naturaleza de sus actividades son objeto de menoscabo en su esfera jurídica elemental.

En este orden de ideas, a continuación se muestran dos casos paradigmáticos de frentes descubiertos por las autoridades laborales en materia de protección de la salud ante las epidemias al interior de las fuentes de trabajo, e igualmente, se expone la vulnerabilidad en que se encuentra el respeto a los derechos de los trabajadores de la salud, particularmente de aquellos que se encuentran en proceso de formación académica.

\section{Tratamiento de epidemias}

\section{A. Virus de inmunodeficiencia humana (VIH)}

Aunque hay algunos avances en lo que respecta al manejo de la información de los trabajadores que han adquirido VIH, específicamente en la Ley Federal de Protección de Datos Personales en Posesión de los Particulares, para que los patrones no manejen sus datos personales sensibles de manera imprudente o comprometan el respeto a su integridad jurídica, persisten diversos vicios 
Este libro forma parte del acervo de la Biblioteca Jurídica Virtual del Instituto de Investigaciones Jurídicas de la UNAM

en las fuentes de trabajo que dejan en incertidumbre los derechos de los operarios que contraen VIH, a saber:

a) La falta de medidas de bioseguridad tanto para los empleados portadores del virus como para aquellas personas que laboran en la misma fuente de trabajo a fin de evitar la transmisión.

b) Mientras la persona con VIH se encuentra sana no tiene garantizado el desempeño de su oficio o profesión en condiciones normales ante cualquier variación efectuada por el patrón sin su consentimiento. Ello debería obligar a este último a cumplir al pie de la letra el contrato individual de trabajo y mantener la relación laboral, más allá de las indemnizaciones económicas con que habitualmente se pretende compensar al trabajador.

c) Los exámenes médicos previos a la contratación de trabajadores carecen de efectos vinculatorios entre el Estado y las fuentes de trabajo. Se encuentran supeditados a la conveniencia de los particulares, donde sólo cuenta la opinión de la parte patronal para su valoración, y ello pone en riesgo las oportunidades de contratación de las personas seropositivas por motivo de discriminación.

d) El Estado no proporciona facilidades al portador de VIH para seguir un tratamiento adecuado ni proporciona atención médica de calidad, mucho menos contribuye a sufragar los gastos médicos que erogan los trabajadores con motivo de la enfermedad.

e) Los fluidos corporales que se consideran potencialmente infecciosos son: sangre y sus derivados, líquido cefalorraquídeo (LCR), líquido sinovial, pleural, peritoneal, pericárdico y amniótico. Si bien el semen y las secreciones vaginales han sido implicados en la transmisión sexual del VIH, no se han asociado a la transmisión ocupacional. Las secreciones nasales, saliva, esputo, sudoración, lágrimas, vómito, orina y heces no se consideran potencialmente infecciosos, salvo que contengan sangre visible. 
Este libro forma parte del acervo de la Biblioteca Jurídica Virtual del Instituto de Investigaciones Jurídicas de la UNAM

\section{B. Influenza AH1N1}

En el caso de afecciones como ésta también existen necesidades pendientes de cubrir que han sido puestas en evidencia por la forma en que en su momento se trató ese padecimiento en las relaciones obrero-patronales. Las deficiencias que se tienen para hacer frente a esta clase de enfermedades en el campo del derecho del trabajo son las siguientes:

a) La falta de utilización de modelos de acción basados en el empleo de principios precautorios, puesto que la propia Ley Federal del Trabajo, en su artículo 132, fracciones XVI, XVII, XVIII y XIX, establece la obligación patronal de contar con un reglamento interno de trabajo adecuado para afrontar las contingencias sanitarias, así como el seguimiento de las normas oficiales mexicanas e indicaciones de la autoridad en materia de seguridad, salud y medio ambiente del trabajo.

b) Existe necesidad de incorporar mecanismos de evaluación inmediata del medio en que el trabajador se desenvuelve una vez que se decreta una contingencia sanitaria, así como de realización de exámenes médicos de manera obligatoria, lo que con la normatividad actual es prácticamente optativo para el sector patronal.

c) Es necesario que las autoridades laborales soliciten y difundan como información pública los índices de cumplimiento de las empresas en el tratamiento de enfermedades epidémicas.

d) Las sanciones ante la falta de rendición de cuentas y seguimiento de normas sanitarias y de seguridad por parte de las empresas deben ir mucho más allá de simples sanciones administrativas, máxime hoy en día, cuando las empresas utilizan modalidades como el outsourcing para allegarse de recursos humanos. Es necesario tipificar delitos en materia laboral por falta de seguridad e higiene en el trabajo, 
Este libro forma parte del acervo de la Biblioteca Jurídica Virtual del Instituto de Investigaciones Jurídicas de la UNAM

dado que continuar con las prácticas habituales pone en peligro el respeto al principal bien jurídico tutelado en beneficio de los trabajadores, que es la vida.

\section{Trabajadores de la salud}

Uno de los rubros con mayores problemas en cuanto a regulación y vulneración de derechos laborales es el de los trabajadores de la salud. Parecería suficiente con la inserción en la Ley Federal del Trabajo de un capítulo sobre trabajos especiales - como es el caso de los médicos residentes - , sin embargo, hay modalidades de relaciones laborales que escapan a la regulación de dicho cuerpo normativo, específicamente, los médicos internos de pregrado.

Estos profesionistas adolecen la falta de una regulación que les permita contar con condiciones laborales inherentes a un contrato individual de trabajo, y ello les lleva a cumplir con deberes que prácticamente rayan en esclavismo moderno.

Entre las vulneraciones a los derechos laborales de los médicos internos de pregrado tenemos las siguientes:

a) $\mathrm{Al}$ artículo 51, fracción II, de la Ley Federal del Trabajo, ya que están inhabilitados para rescindir su relación laboral por causa de malos tratamientos, faltas de honradez, violencia, hostigamiento y/o acoso sexual, entre otras, con el consecuente pago de indemnizaciones que correspondería en una relación laboral ordinaria.

b) Quedan sin efectos las prohibiciones patronales contra el hostigamiento y/o acoso sexual establecidas en el artículo 133, fracciones XII y XIII, de la Ley Federal del Trabajo, respectivamente, ya que los médicos internos de pregrado no tienen un patrón en sentido formal.

c) Igualmente, carecen de efectividad las infracciones previstas en el artículo 994 de la ley en contra de patrones 
Este libro forma parte del acervo de la Biblioteca Jurídica Virtual del Instituto de Investigaciones Jurídicas de la UNAM

que incumplan con deberes como pago de prestaciones, seguridad e higiene y contra el hostigamiento y/o acoso sexual.

d) Todo lo relativo a la protección de los derechos de estos trabajadores se encuentra plasmado en una Norma Oficial Mexicana, lo que en sí mismo constituye un acto de discriminación tajante, pues los artículos 20 y 21 de la Ley Federal del Trabajo establecen los requisitos para configurar la existencia de una relación laboral y, por consiguiente, de un contrato individual de trabajo: a) trabajo personal, b) subordinación y c) pago de salario. ${ }^{2}$

Debemos recordar que en el capítulo XVI de la Ley Federal del Trabajo, en donde se regula el trabajo de médicos residentes en periodo de adiestramiento en una especialidad - específicamente el artículo 353-A de dicha ley-, señala que para los efectos del mencionado capítulo, se entiende por médico residente "el profesional de la medicina con título legalmente expedido y registrado ante las autoridades competentes, que ingrese a una unidad médica receptora de residentes, para cumplir con una residencia". Por otra parte, el artículo 353-I de la Ley Federal del Trabajo establece que las disposiciones del capítulo XVI "no serán aplicables a aquellas personas que exclusivamente reciben cursos de capacitación o adiestramiento, como parte de su formación profesional, en las instituciones de salud".

Puesto que los médicos de pregrado reúnen los requisitos antes señalados deben ser tratados como trabajadores, aunque sea de naturaleza eventual. Asimismo, tienen que recibir los mismos emolumentos que los médicos a los cuales asisten, pues muchas veces su nivel de responsabilidad es igual o mayor que el de los médicos titulares que trabajan en los hospitales. Esto último en concordancia con el contenido del artículo 56 de la Ley Federal del Trabajo, que dispone:

2 Cámara de Diputados del H. Congreso de la Unión, Ley Federal del Trabajo, México, 2016, p. 6. 
Este libro forma parte del acervo de la Biblioteca Jurídica Virtual del Instituto de Investigaciones Jurídicas de la UNAM

Las condiciones de trabajo basadas en el principio de igualdad sustantiva entre mujeres y hombres en ningún caso podrán ser inferiores a las fijadas en esta Ley y deberán ser proporcionales a la importancia de los servicios e iguales para trabajos iguales, sin que puedan establecerse diferencias y/o exclusiones por motivo de origen étnico o nacionalidad, sexo, género, edad, discapacidad, condiciones de embarazo, salvo las modalidades expresamente consignadas en esta Ley.

Finalmente, y dado que el salario es la base para el pago de prestaciones laborales, el artículo 86 de la Ley Federal del Trabajo es contundente: "a trabajo igual, desempeñado en puesto, jornada y condiciones de eficiencia también iguales, debe corresponder salario igual".

\section{CONGLUSIÓN: LA PERSPECTIVA DE GÉNERO}

El Observatorio Europeo de Riesgos señala que las mujeres son más propensas a contraer infecciones, ya que ocupan puestos de trabajo con un nivel de riesgo biológico y exposición más elevado. ${ }^{3}$

A partir de la firma y ratificación por México de la Convención sobre la Eliminación de Todas las Formas de Discriminación Contra la Mujer se han abierto nuevas perspectivas para la consolidación de un marco jurídico que permita una nueva ruta democrática para la valorización social y cultural de las mujeres, en la que se les despoje de todo aquello que provoque su discriminación y su exclusión de la vida social. ${ }^{4}$

3 Documento del Observatorio Europeo de Riesgos, disponible en: scielo. isciii.es/pdf/mesetra/v53n209/original8.pdf.

4 Álvarez de Lara, Rosa María, "Democracia y derechos de las mujeres", Género y derecho, México, Popocatépetl, 2010, p. 213. Citada por Carrasco Fernández, Felipe Miguel, "Discriminación laboral por motivos de género", en Sánchez-Castañeda, Alfredo et al. (coords.), Condiciones de trabajo y seguridad social, 
Este libro forma parte del acervo de la Biblioteca Jurídica Virtual del Instituto de Investigaciones Jurídicas de la UNAM

REGULAGIÓN DE LA PROTECGIÓN DE LOS TRABAJADORES...

Es necesario denunciar y promover los cambios en el sector laboral necesarios para lograr una perspectiva de equidad de género en el trabajo, evitando la discriminación laboral de género. ${ }^{5}$

\section{TABLA II. Recursos para el cuidado de la salud (2010)}

\begin{tabular}{|c|c|c|}
\hline Recursos & México & Promedio OCDE* \\
\hline Médicos por 1,000 habitantes & 2.0 & 3.1 \\
\hline Enfermeras por 1,000 habitantes & 2.5 & 8.7 \\
\hline $\begin{array}{c}\text { Médicos graduados por 100,000 } \\
\text { habitantes }\end{array}$ & 1.6 & 10.3 \\
\hline $\begin{array}{c}\text { Enfermeras graduadas por } \\
100,000 \text { habitantes }\end{array}$ & 9.8 & 39.8 \\
\hline $\begin{array}{c}\text { Camas de hospital por } 1,000 \\
\text { habitantes }\end{array}$ & 1.6 & 0.7 \\
\hline $\begin{array}{c}\text { Camas de cuidados psiquiátricos } \\
\text { por 1,000 habitantes }\end{array}$ & 0 & 12.5 \\
\hline $\begin{array}{c}\text { Unidades de MRI (imagen por } \\
\text { resonancia magnética) por } 1,000 \\
\text { habitantes }\end{array}$ & 2.0 & 22.6 \\
\hline Tomografía axial computarizada & 4.8 & 4.9 \\
\hline
\end{tabular}

*Organización para la Cooperación y el Desarrollo Económicos.

Universidad Autónoma del Estado de Morelos-UNAM, Instituto de Investigaciones Jurídicas, 2012.

5 Mendizábal Bermúdez, Gabriela et al. (coords.), Condiciones de trabajo y seguridad social, México, Universidad Autónoma del Estado de Morelos-UNAM, Instituto de Investigaciones Jurídicas, 2012. 
Este libro forma parte del acervo de la Biblioteca Jurídica Virtual del Instituto de Investigaciones Jurídicas de la UNAM www.juridicas.unam.mx

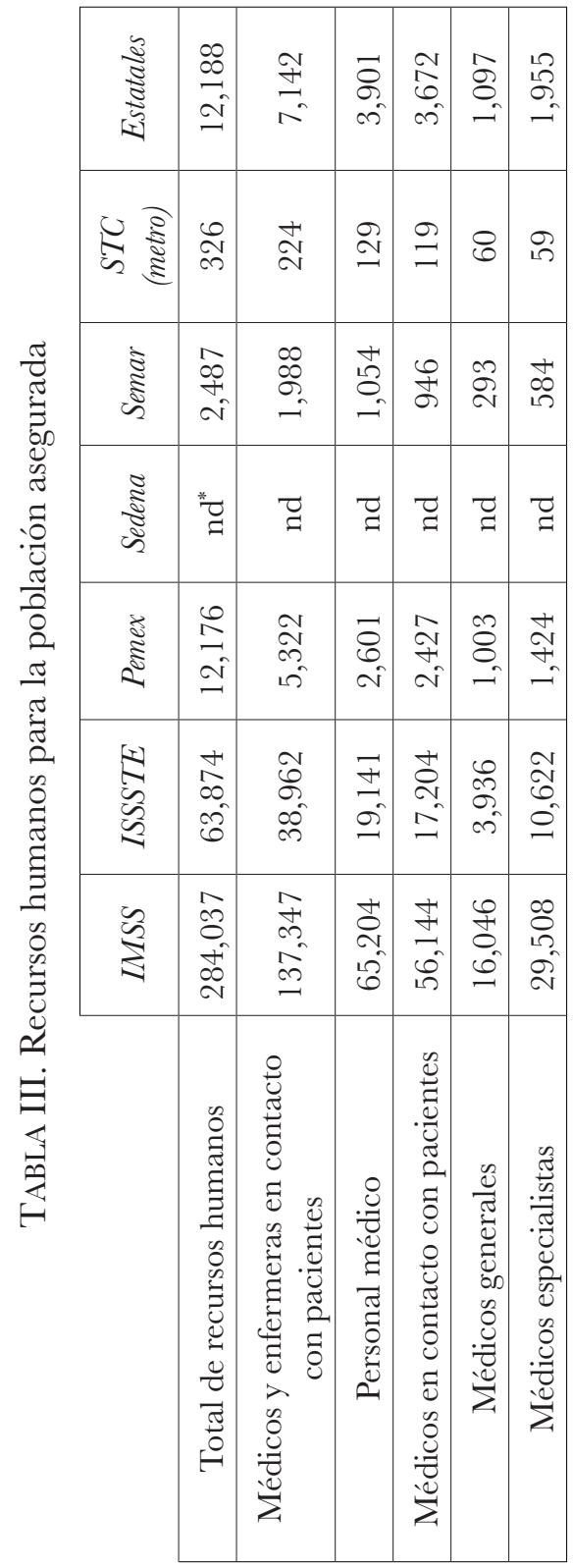

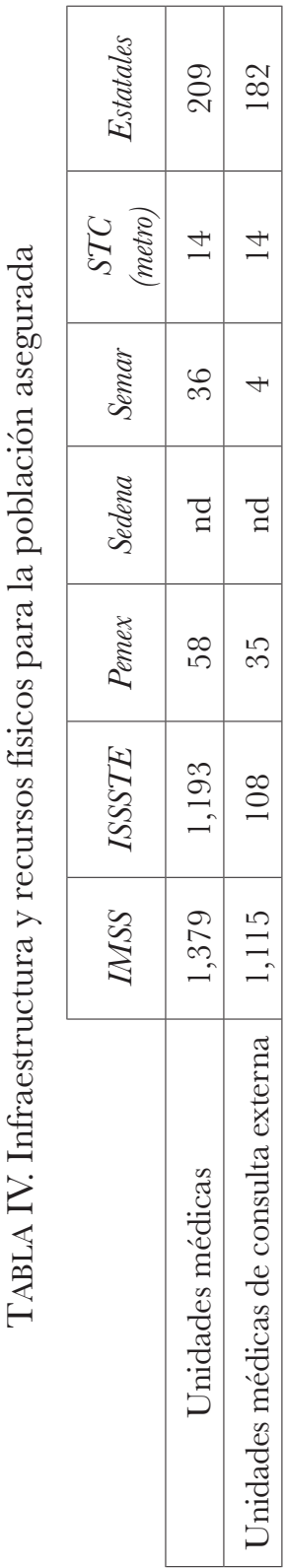


Este libro forma parte del acervo de la Biblioteca Jurídica Virtual del Instituto de Investigaciones Jurídicas de la UNAM

REGULACIÓN DE LA PROTEGCIÓN DE LOS TRABAJADORES...

TABLA V. Recursos humanos para población no asegurada

\begin{tabular}{|c|c|c|c|}
\cline { 2 - 4 } \multicolumn{1}{c|}{} & SSa & IMSS & Universitarios \\
\hline Total de recursos humanos & 284,142 & 17,553 & 8,511 \\
\hline $\begin{array}{c}\text { Médicos y enfermeras en } \\
\text { contacto con pacientes }\end{array}$ & 167,852 & 12,030 & 4,437 \\
\hline Personal médico & 78,180 & 5,655 & 1,972 \\
\hline Médicos generales & 21,839 & 2,261 & 144 \\
\hline Médicos especialistas & 28,491 & 153 & 1,191 \\
\hline $\begin{array}{c}\text { Médicos de especialidades } \\
\text { básicas }\end{array}$ & 12,099 & 40 & 433 \\
\hline
\end{tabular}

TABLA VI. Infraestructura y recursos físicos para población no asegurada

\begin{tabular}{|c|c|c|c|}
\cline { 2 - 4 } \multicolumn{1}{c|}{} & SSa & IMSS & Universitarios \\
\hline Unidad médica & 13,477 & 3,620 & 15 \\
\hline $\begin{array}{c}\text { Unidades médicas de con- } \\
\text { sulta externa }\end{array}$ & 12,828 & 3,550 & 1 \\
\hline Unidades hospitalarias & 649 & 70 & 14 \\
\hline Consultorios & 30,336 & 4,403 & 665 \\
\hline Consultorios generales & 18,345 & 3,952 & 50 \\
\hline $\begin{array}{c}\text { Consultorios de especiali- } \\
\text { dades básicas }\end{array}$ & 2,277 & 271 & 179 \\
\hline
\end{tabular}

Finalmente, y según el criterio de la Suprema Corte de Justicia de la Nación, se considera que "siendo el trabajo una fuerza puesta al servicio de una empresa, los desperfectos que esa fuerza sufre, deben entrar en los gastos generales de la negociación, de la misma manera que quedan comprendidos en ellos, 
Este libro forma parte del acervo de la Biblioteca Jurídica Virtual del Instituto de Investigaciones Jurídicas de la UNAM

las reparaciones de la maquinaria y demás útiles e instrumentos de trabajo". ${ }^{6}$

Por la vía de la legislación del trabajo se reitera el principio de la expansión del derecho social laboral. En los años recientes se han incorporado a los beneficios del orden jurídico laboral los trabajadores burócratas, los médicos residentes en periodo de adiestramiento, los trabajadores universitarios, los trabajadores al servicio de las instituciones públicas de banca y crédito y, después de muchos años, los trabajadores al servicio de los gobiernos de las entidades federativas y de los municipios. ${ }^{7}$

6 Tesis Aislada (Laboral) 380567, Semanario Gudicial de la Federación y su Gaceta, Quinta Época, t. LIII, p. 417, disponible en: https://sif.scjn.gob.mx/sifsist/ Paginas $/$ DetalleGeneralV2.aspx:ID $=380567 E^{2}$ Clase $=$ Detalle TesisBLESemanario $=0$.

7 Lara Sáenz, Leoncio, Cuestiones laborales, México, Secretaría del Trabajo y Previsión Social-Procuraduría Federal de la Defensa del Trabajo, 1984, Colección Ensayos sobre el trabajo, Serie Derecho del trabajo y previsión social, cuestiones laborales. 
Este libro forma parte del acervo de la Biblioteca Jurídica Virtual del Instituto de Investigaciones Jurídicas de la UNAM

\title{
EL MODELO EUROPEO PARA LA REGULAGIÓN DEL MANEJO DEL RIESGO BIOLÓGICO
}

\author{
Simon LINDSAY*
}

\author{
SUMARIO: I. Introducción. II. La problemática en el Reino \\ Unido. III. La situación en Europa. IV. La importancia de la \\ inspeccion: el Health and Safety Executive.
}

\section{INTRODUCCIÓN}

Muchísimas gracias a la UNAM por la amable invitación para exponer en este texto mis ideas sobre la regulación del manejo del riesgo biológico en Europa y el Reino Unido. Soy abogado y únicamente ejerzo en litigios que involucran hospitales y médicos; hay mucho litigio en cuanto a demandas contra médicos y enfermeras. Supongo que la mayoría de los lectores de este texto serán profesionales del cuidado de la salud, lo cual me es muy útil porque me ayuda a enfocar mi presentación, de la cual primero haré una breve introducción.

Alguien me ha comentado que en México existen bastantes reglas, pero que nadie cumple con ellas. Si lo que les voy a afirmar sirve de algún consuelo, en el Reino Unido muchos dicen que la situación no es diferente. Los abogados y los legisladores

* Abogado en la firma Bevan Brittan LLP | Lawyers for the public, private and third sectors, Reino Unido, y experto en derecho del sector salud. Este texto es producto de la versión estenográfica traducida y editada por personal del Instituto de Investigaciones Jurídicas de la UNAM. 
Este libro forma parte del acervo de la Biblioteca Jurídica Virtual del Instituto de Investigaciones Jurídicas de la UNAM

se mantienen muy ocupados escribiendo leyes que nadie cumple. $\mathrm{Y}$ esto que afirmo es una experiencia multifacética que abre diferentes rutas y perspectivas de análisis.

\section{LA PROBLEMÁTICA EN EL REINO UNIDO}

No voy a explicar en este texto que en el Reino Unido todo funciona de maravilla porque no es así. Por ejemplo, hace nueve años en el Reino Unido surgió una amenaza con relación al surgimiento de los patógenos resistentes a ciertos antibióticos, y en mi país había un temor genuino respecto a que esto iba a provocar una explosión de litigios. De hecho, hay en mi país una organización que está a cargo de lidiar con estas cuestiones, pero no podemos enfrentar el problema sino hasta conocer el alcance del mismo, por lo que una iniciativa que se emprendió ante esta problemática fue que a todos los hospitales en Inglaterra y Gales se les requiriera presentar, cada mes, un reporte sobre la bacteriemia en sus diferentes salas y pabellones.

Esta información se mantiene en un sitio web y permite entender el nivel de bacteriemia que se presenta en muchos hospitales mensualmente. Como por ejemplo, hubo un hospital en particular que no se desempeñó tan bien, al grado que tuvo que intervenir el ministro de Salud, y mucha gente decía "yo no voy a ir a ese hospital". Lo anterior ocasionó mucha presión con respecto a los hospitales para tratar con esta problemática, y por supuesto, se cumplió con los reglamentos, pero la presión fue real.

Ahora bien, quisiera comentar que en alguna ocasión tuve una reunión con profesionales del cuidado de la salud y uno de ellos me dijo que a su hospital llegaban muchas lesiones por objetos punzocortantes; y me dijeron también que si eso se reportara de la manera que es en realidad, se producirían nuevas políticas en el tema y que habría cambios. 
Este libro forma parte del acervo de la Biblioteca Jurídica Virtual del Instituto de Investigaciones Jurídicas de la UNAM

\section{LA SITUACIÓN EN EUROPA}

Es algo artificial hablar acerca del "modelo europeo" para el manejo de los riegos biológicos, pero la pregunta clave, creo yo, es si existe un modelo como tal; y si existe, ¿cómo funciona? En cuanto a la segunda pregunta, eso quiere decir, más bien, ¿esto va a disminuir los juicios?

Primero, una de las cuestiones más importantes al tratar con el modelo europeo es el hecho de que la ley europea, el derecho europeo, se impondría o prevalecería sobre la ley nacional. Entonces tendrían ustedes un régimen supranacional, y ésta es una fuente de irritación muy fuerte para muchos políticos nacionales.

Para poder entender a cabalidad el modelo europeo hay que comprender que opera sobre la base de una ley que tiene prevalencia sobre leyes nacionales. Pero antes de seguir adelante quisiera dar una breve introducción acerca de lo que es y significa la Unión Europea, la cual no es tan distinta a lo que tienen en los Estados Unidos, México y Canadá con el Tratado de Libre Comercio de América del Norte (TLCAN).

La Unión Europea, fundada en 1957, reúne a veintiocho Estados miembros - de Finlandia hasta Grecia, pasando por muchos otros países - El propósito de esta unión fue prevenir la posibilidad de otra guerra en Europa. Y tenemos incluso una bandera europea, la cual para mucha, o la mayor parte de la gente, es un símbolo. Ahora, la Unión cuenta con una población de 508 millones e inicialmente se le denominó Comunidad Económica Europea, con propósitos fundamentalmente económicos, pero después hubo un cambio, un movimiento, un deseo de acercar más a la Unión Europea para hacerla como son los Estados federales. Esto tiene significados muy importantes en Europa, ya que la intención original fue crear un movimiento libre de mercancías, personas y dinero, pero pronto quedó claro que lo anterior no se podía hacer sin políticas fiscales y otras cosas comunes, por ejemplo, con respecto a los derechos humanos. Se puede decir que la Unión Europea ha sido exitosa - se ayudó a 
Este libro forma parte del acervo de la Biblioteca Jurídica Virtual del Instituto de Investigaciones Jurídicas de la UNAM

Croacia en la década de los noventa del siglo pasado para que superara su conflicto interno-, pero sería equivocado sugerir que todo ha sido color de rosa.

Supongo que todos ustedes han escuchado el término brexit, el cual se refiere a la salida de Gran Bretaña de la Unión Europea (Britain-exit). En este proceso, en el Reino Unido vamos a decidir si nos quedamos en la Unión o no. ${ }^{1}$ Quisiera ser muy honesto con respecto a esto: yo creo que debemos quedarnos. Esto es un ejemplo del aislamiento, de hecho, esto es parte de un problema nacional del Reino Unido desde hace muchos años.

Ahora tenemos que el señor Boris Johnson, quien fuera alcalde de Londres $-\mathrm{y}$ que, por cierto, se parece un poco a Donald Trump, no sólo en lo físico-, decía que la legislación europea es incompatible con la ley inglesa o galesa, con Gran Bretaña en general; por ello - dijo Johnson - Gran Bretaña tenía que elegir su propia legislación y no estar supeditada a todo el resto de Europa.

El principio fundamental de la Unión Europea es que cada Estado miembro cede parte de su soberanía. Así, por medio de los tratados que han dado origen a la Unión, los Estados cedieron parte de su soberanía para poder crear las instituciones de la Unión, mismas que tienen atribuciones para hacer o adoptar leyes que obliguen a los Estados miembros. Las instituciones de la Unión Europea son el Consejo Europeo que, básicamente, son todos los jefes de Estado de los Estados miembros que se reúnen cada seis meses y discuten las políticas generales. Asimismo, existe un Consejo de la Unión Europea, el cual está constituido por los ministros del mismo tema de los veintiocho países miembros, quienes discuten políticas y directrices relativas a sus respectivas materias o temas. Y existe, también, la llamada Comisión Europea, integrada por personas designadas por los gobiernos de los Estados miembros, y que tienen a su cargo proponer y elaborar la legislación europea. Ésto es algo que irrita a muchos políticos nacionales, pues

1 Nota del editor: el presente texto se redactó antes del referéndum que decidió la salida del Reino Unido de la Unión Europea. 
Este libro forma parte del acervo de la Biblioteca Jurídica Virtual del Instituto de Investigaciones Jurídicas de la UNAM

sus integrantes no son democráticamente elegidos, a diferencia del Parlamento Europeo, que sí se elige - tiene más o menos setecientos miembros-. Así, quien produce el derecho europeo es la Comisión Europea, cuyos productos normativos se convierten en ley en todos los Estados individuales — si bien existe la posibilidad de que si a algún Estado miembro no le conviene, puede presentar una objeción y exponer las razones por las que no puede implementarse en su sistema en particular-.

Si, por decir algo, hay una ley en el Reino Unido que entra en conflicto con un reglamento de la Comisión Europea, esa ley no se puede aplicar. Además, hay directivas propuestas por la referida Comisión, mismas que tienen que ser implementadas en la ley nacional.

Las decisiones son declaraciones de la Comisión que se utilizan y que son obligatorias para las personas afectadas, por lo general compañías; por ejemplo, en cuestiones fiscales y cosas de este tipo, las regulaciones o reglamentos y las directivas son lo principal. Puedo mencionar una directiva relativa a objetos punzocortantes, la cual se aprobó en 2010 y, por supuesto, se puso en marcha en 2013. El 22 de mayo del 2013 el Reino Unido puso en vigor esta directiva sobre objetos punzocortantes - ha habido muy pocas que específica y exclusivamente tengan que ver con el cuidado de la salud - , que tuvo una génesis muy larga y estableció un tiempo límite para que cada uno de los Estados aprobara una ley que permitiera aplicar dicha directiva en cada país.

Esta directiva cubre una amplia gama de reglas, pero se enfoca específicamente al uso de objetos punzocortantes en ambientes médicos, hospitales, asilos médicos generales, espacios para cirugías, salas de operación y, en general, todo tipo de ambientes a los que la gente llega y entra en contacto con objetos como jeringas, escalpelos y otros semejantes que podrían provocar lesiones.

En relación con esta ley sobre el impacto de lesiones por objetos punzocortantes puedo decir, como abogado practicante, que la seguridad de los pacientes puede ser muy importante en 
Este libro forma parte del acervo de la Biblioteca Jurídica Virtual del Instituto de Investigaciones Jurídicas de la UNAM

el Reino Unido. Recordemos que si un abogado dice que esto representa un buen negocio, es una mala noticia para los que tienen que pagar impuestos y no tan buena para quienes son los profesionales de la salud. Para ejemplificar: en el Reino Unido, en 2014-2015, hubo 50,000 demandas por incidentes de pacientes afectados contra el Servicio Nacional de Salud (National Health Service o NHS) - que vendría siendo lo que es el IMSS en México-, el cual es un servicio estatal, es decir, público. Pues bien, en 2014 el costo para el NHS derivado de este tipo de incidentes fue de 1.7 mil millones de libras esterlinas, costo que corresponde a un solo año - si bien hay que considerar que las demandas se llevan tiempo para quedar resueltas-.

También hay casos en que las personas ofendidas o lesionadas fueron los cirujanos o las enfermeras, los cuales representaron $32 \%$ de estas demandas. El valor más grande por ellas fue el de las demandas obstétricas, representando entre 15 y 20 millones, lo cual equivale al $42 \%$ del costo total. En cuanto a las lesiones por instrumentos punzocortantes, se ha dicho en investigaciones que los incidentes han crecido un 49\% de 1999 al 2005.

El costo de las lesiones por instrumentos punzocortantes que afectan a los profesionales de la salud es enorme. Si una enfermera, por ejemplo, tiene que ir a un curso y a terapia, un doctor se tiene que ir de incapacidad o si alguien recibe un patógeno, va a costar de 100,000 a 500,000 libras esterlinas por año. Asimismo, investigaciones recientes sugieren que la mayoría de las lesiones derivan de incidentes con jeringas desechables. El costo derivado de estas lesiones también es importante, pues se ha calculado en, más o menos, 6.7 millones de libras - solamente por compensaciones que fueron pagadas a los profesionales de la salud - . Los hospitales podrían decir que fue culpa de estos últimos, pero éstos dirían que los hospitales debieron de haber tenido un sistema bien diseñado para proteger a todo su personal; si no es así, entonces es algo muy sencillo para una enfermera y un doctor mostrar que los sistemas del hospital estaban en falta y fallaron. Ha habido veinte casos en los cuales los profesionales 
Este libro forma parte del acervo de la Biblioteca Jurídica Virtual del Instituto de Investigaciones Jurídicas de la UNAM

de la salud han sido infectados con algún patógeno, lo que les ha llevado a la muerte, y también gente que ha quedado incapacitada como resultado de haber obtenido virus de inmunodeficiencia humana (VIH), síndrome de inmunodeficiencia adquirida (SIDA) o hepatitis.

Pero regresando a la ley, si se examina el marco legislativo existente en el Reino Unido, éste es exhaustivo; incluso tenemos reglas para el control de sustancias dañinas a la salud. Se trata de sustancias que deben manejarse con gran cuidado; debe haber una valoración de riesgo y personal capacitado para manejarlas, así como un sistema de reporte. Y si alguien queda expuesto al patógeno, pues entonces la persona debe saber a quién acudir para protegerse, o bien, saber cómo protegerse ella misma.

Asimismo, en el Reino Unido existe reglamentación de salud y seguridad, la cual exige que todos los patrones tengan sistemas bien instalados, o sea, una política que le diga a la gente cómo debe manejar las sustancias dañinas de las que hablamos, y existen reglas para la provisión y el uso de equipo de trabajo; es decir, cada hospital debe tener una política que requiera que las enfermeras usen guantes dobles, doble uniforme o manga larga, o que los doctores no lleven corbata. Esto es muy exhaustivo también, y cubre todos los aspectos que implican un riesgo para los trabajadores de la salud. Adicionalmente, esta reglamentación implica que si no se cumple con la norma se va a tener que pagar cierta compensación o una sanción. Así es como han surgido guías para la excelencia, o bien, un código muy completo para la prevención y el control de infecciones.

Por otra parte, si un profesional no cumple con el código de práctica no necesariamente termina yendo ante un tribunal, pero hay otras formas de asegurarnos que pague por el hecho de no cumplirlo. Una de esas formas se da a través de la Care Quality Commission (CQG), la cual es lo que en Gran Bretaña se denomina un regulador de los servicios sociales de salud. Esta instancia acude a los hospitales para realizar inspecciones y después elabora un reporte, el cual se publica en su sitio web. Asimismo, 
Este libro forma parte del acervo de la Biblioteca Jurídica Virtual del Instituto de Investigaciones Jurídicas de la UNAM

dicho reporte se publica en los periódicos locales, es examinado por el ministro de Salud y también por todo tipo de personas que tienen interés en saber cómo está funcionando un determinado hospital; si lo está haciendo bien o no.

La CQG está facultada para pedirle a cualquier hospital información acerca de cómo se maneja con su personal. Es importante recordar que si los profesionales del cuidado de la salud son parte de una visión feliz y eficiente dentro de su centro de trabajo, esto se traduce en seguridad para ellos y los pacientes. No importa cuántas leyes haya. Y la verdad es que no se pueden implementar esas leyes si el personal no está contento; y si la CQC visita un hospital y no le gusta lo que ve, la administración de ese hospital podría comenzar a recibir llamadas telefónicas del Ministerio de Salud, además de que va a tener mucha presión social, que es un componente muy importante en relación con la forma en que la regulación sobre los instrumentos punzocortantes se implementa. Éste es un concepto básico: si el personal no está seguro, entonces sus pacientes no estarán seguros.

Una de las cosas que ya no están de moda es que en el personal de enfermería haya héroes o heroínas que acepten riesgos por el bien del paciente. Ésto ya no es aceptable. Y tampoco se acepta ya que los doctores digan que no van a usar un elemento o material determinado porque eso debe hacerlo la enfermera. Entonces, lo que se está aplicando en los hospitales es una cultura de controles; una cultura de control de infecciones, y como parte de esto, debemos resaltar que hay muchas investigaciones que permiten decir que la capacitación y el uso adecuado de los dispositivos son útiles para reducir los incidentes hasta en un 60\%.

Pero regresemos al modelo europeo. La directiva sobre objetos punzocortantes tiene muchos conceptos del manejo de los diversos instrumentos. En cualquier hospital hay riesgos de que alguna persona pueda sufrir una lesión por esos instrumentos, por lo que la directiva nos dice que la posibilidad de exposición de los trabajadores de la salud debe quedar eliminada, como una obligación. No es algo que queda a discreción de la administra- 
Este libro forma parte del acervo de la Biblioteca Jurídica Virtual del Instituto de Investigaciones Jurídicas de la UNAM

ción del hospital. Se requiere que esta última elimine ese riesgo, y eso implica usar mecanismos de seguridad específicos, tales como jeringas especiales con punta controlada y muchos otros dispositivos de seguridad.

Como mencioné anteriormente, la directiva debe entrar en vigor a través de una ley nacional. Todos los países en la comunidad europea deben aplicar la directiva de esta forma, si bien hay cierto margen de variación en cuanto a la aplicación. Por ejemplo, en Alemania la ley ha dispuesto que las jeringas seguras deberían de usarse solamente si el paciente lleva ya un virus; sólo en esas ocasiones deberían usarse ese tipo de jeringas. Por su parte, en Inglaterra, Gales y Escocia la posición fue un poco diferente. La reglamentación sobre los instrumentos punzocortantes de 2013 dispuso que el hospital debía asegurarse de usar estos instrumentos punzocortantes, o jeringas seguras, en los espacios donde sea razonable. Pero lo que es razonable depende mucho de las circunstancias; podría ser, tal vez, que tengas un espacio en un hospital donde hay muy poco riesgo de que alguien se contamine con un patógeno transmitido por sangre, digamos, el área pediátrica, y esto le da cierta flexibilidad al esquema. Asimismo, lo que se empezó a decir cuando inició la implementación de la referida ley es que debe haber una evaluación de riesgo, se debe dar un paso positivo para decidir si se está preparado para aceptar tal riesgo y luego mostrar que ese riesgo queda justificado, y es mucho más difícil de lo que se pueda pensar.

Por lo anterior, a pesar de que la citada directiva es obligatoria para todos los miembros de la Unión Europea, su aplicación varía; es decir, no hay un modelo europeo propiamente dicho en esta materia, pero sí un marco europeo que permite mucha discrecionalidad local al momento de aplicar las leyes nacionales. En el Reino Unido, por ejemplo, se debe pensar si es razonable o no usar los instrumentos punzocortantes en determinadas circunstancias, o se debe considerar si el cuidado del paciente queda comprometido, como también si el instrumento punzocortante es confiable, si hay buenas políticas para los dispositivos 
Este libro forma parte del acervo de la Biblioteca Jurídica Virtual del Instituto de Investigaciones Jurídicas de la UNAM

punzocortantes, si el personal está bien capacitado, prever las situaciones que pueden surgir - como que, tal vez, el paciente empuje a la enfermera mientras inyecta con la jeringa-, pensar cómo se puede usar de manera más fácil un dispositivo y también cuál es el ambiente más apropiado para el empleo de los instrumentos punzocortantes. El énfasis está puesto en reducir el riesgo a cero, lo que en buena medida se traduce en que deben usarse jeringas más seguras.

\section{LA IMPORTANCIA DE LA INSPECGIÓN: EL HeALTh AND SAFETy EXecutive}

Por último, en el Reino Unido tenemos también la llamada Health and Safety Executive (HSE), que es una agencia que inspecciona y aplica sanciones en el tema de seguridad y salud en los centros de trabajo; en todos los espacios donde haya trabajadores, no solamente en hospitales. Esta agencia exige que en los centros de trabajo haya políticas de evaluaciones de riesgos; de no tenerlas, o de tenerlas de manera inadecuada, se pueden desprender sanciones. Asimismo, cabe aclarar que en Inglaterra tener una mala o inadecuada evaluación de riesgo en el centro de trabajo es una ofensa criminal.

Hasta ahora solamente ha habido dos sanciones para hospitales en relación con el tema de instrumentos punzocortantes. Lo que la HSE puede decir a un hospital es que si no mejora sus registros o si no mejora sus políticas y no tiene evaluación de riesgos, crucialmente, si el hospital no puede demostrar que tiene una evaluación de riesgo que sí funcione, entonces, potencialmente, está cometiendo una ofensa criminal, y se puede llegar a un juicio donde el hospital puede tener una buena sentencia condenatoria o una multa, pero incluso, en teoría, por esto se puede cerrar un hospital - si bien creo que esto nunca pasará, solamente cambiarían al administrador del hospital de trabajo-. Además, en el Reino Unido juega un papel muy importante la pre- 
Este libro forma parte del acervo de la Biblioteca Jurídica Virtual del Instituto de Investigaciones Jurídicas de la UNAM

sión social y la publicidad negativa. Yo no sé si sea lo mismo en México, pero en el Reino Unido el NHS está en el centro de los debates de la opinión pública; la gente lo ama o lo odia. Y es muy común que salga en los periódicos, que se le discuta en el Parlamento o lleguen pleitos a los tribunales en donde se le involucre.

El HSE también hace recomendaciones de mejoras - ha habido veintiún recomendaciones desde 2013-, y en resumen, en ellas el HSE ha dicho que la evaluación de riesgo de los hospitales respectivos es inadecuada, lo mismo que sus políticas, y que no han demostrado que funcionen - aun cuando no haya habido lesionados - . Por el solo hecho de no tener políticas adecuadas se incurre ya en un delito. Los ejecutivos de la HSE visitan los hospitales y piden ver sus tablas de lesiones ocurridas a lo largo del año bajo examen, y si el hospital no puede proporcionar estos datos, entonces se les da una recomendación, que si no es adoptada, el hospital se puede hacer acreedor a una sanción o se le puede llevar a juicio.

Todo esto quiere decir que los hospitales deben tener una evaluación de riesgo apropiada. Si no la tienen, desde ahí están mal, inclusive sin tener lesionados; y deben demostrar que han dado pasos apropiados para tener esas evaluaciones y para que el personal esté debidamente capacitado. Pero las reglas solas no trabajan, debe haber un marco adecuado para aplicarlas y así hacer la diferencia. 
Este libro forma parte del acervo de la Biblioteca Jurídica Virtual del Instituto de Investigaciones Jurídicas de la UNAM

\title{
REGULACIÓN BASADA EN RIESGOS PARA PREVENIR LESIONES BIOLÓGICAS DEL TRABAJADOR DE LA SALUD EN MÉXICO
}

\author{
María de Jesús Medina Arellano*
}

\begin{abstract}
SUMARIO: I. Introducción. II. Dispositivos punzocortantes y lesiones biológicas. III. Guías internacionales. IV. Prevalencia de lesiones por riesgos biológicos (punciones o pinchazos accidentales) de los trabajadores de la salud en México. V. Esquema nacional normativo de riesgo de trabajo y salud ocupacional de los trabajadores de la salud. VI. Reflexión: ¿regulación basada en riesgos? VII. Fuentes de consulta.
\end{abstract}

\section{INTRODUCGIÓN}

La seguridad y salud en el trabajo es un derecho humano fundamental de acuerdo con la Declaración Universal de los Derechos Humanos (1948): "Todo individuo tiene derecho a la vida, al trabajo $[\ldots]$ a condiciones equitativas y satisfactorias de trabajo $[\ldots]$ Toda persona tiene derecho a un nivel de vida adecuado que le asegure, así como a su familia, la salud y el bienestar". Por otro lado, México, el 9 de septiembre de 1931, se adhirió a la Organización Internacional del Trabajo (OIT, suscrita en Versalles, Francia, el 28 de junio de 1919), y los últimos datos que nos presenta la OIT en esta materia son aterradores: hasta el 2009 se tenía el

* Doctora en Bioética y jurisprudencia médica. Investigadora del Instituto de Investigaciones Jurídicas de la UNAM. 
Este libro forma parte del acervo de la Biblioteca Jurídica Virtual del Instituto de Investigaciones Jurídicas de la UNAM

reporte de que cada quince segundos moría un trabajador a causa de un accidente o enfermedad relacionada con el trabajo. ${ }^{1}$ Derivado de lo detallado anteriormente, la OIT ha instaurado el día 28 de abril como el "día mundial de la seguridad y salud en el trabajo".

En nuestro país, independientemente de que el derecho de protección a la salud es un derecho fundamental establecido en el artículo 4o. constitucional, también está estrechamente ligado a la prerrogativa de la protección de la salud en el trabajo establecida en el artículo 123 constitucional, en sus fracciones XXIX, apartado A, y XI, apartado B, que son derechos humanos que deberán ser garantizados a través de la legislación federal y de instrumentos y políticas públicas que sean necesarios para salvaguardar y observar los mismos (seguridad y solidaridad social). Toda vez que la afectación de la salud de cualquier individuo lo privaría de desarrollar su actividad laboral y pone en riesgo su calidad y viabilidad de vida. ${ }^{2}$ En el apartado respectivo exploraremos los cuerpos normativos vigentes en estos rubros y se hará un pequeño análisis de ese marco jurídico — que en ocasiones no es fácil de ubicar en una realidad con un contexto social complejo y confuso-.

En el área de la salud, específicamente en investigación y aplicación clínica, encontramos tres campos de regulación: 1) normas que tienen por objeto prevenir el traslado o contagio entre especies a través de seres humanos, animales y plantas (biodiversidad); 2) normas de seguridad alimentaria, y 3) normas que buscan la bioseguridad y promoción de prevención y gestión de riesgos a los cuales están expuestos los trabajadores de la salud (TDS) en los espacios clínicos y de laboratorio. En la literatu-

1 Oficina Internacional del Trabajo, Salud y vida en el trabajo: un derecho fundamental, Ginebra, 2009, disponible en: http://wwre.ilo.org/womsp5/groups/public/ ---ed_protect/---protrav/---safework/documents/publication/woms_151828.pdf.

2 Sánchez Castañeda, Alfredo, La seguridad y la protección social en México. Su necesaria reorganización, México, UNAM, Instituto de Investigaciones Jurídicas, 2012. 
Este libro forma parte del acervo de la Biblioteca Jurídica Virtual del Instituto de Investigaciones Jurídicas de la UNAM

ra médica se reporta el riesgo de sufrir un accidente por algún tipo de objeto punzocortante o la posibilidad de contaminarse o salpicarse con líquidos corporales potencialmente infecciosos, como sangre, orina, líquido cefalorraquídeo o líquido peritoneal, además de la exposición en el traslado de sustancias tóxicas o infecciosas. $^{3}$

\section{DisPositivos PUNZOCORTANTES Y LESIONES BIOLÓGICAS}

Las lesiones más recurrentes, según lo demuestra la literatura médica, se centran en el riesgo biológico al cual están expuestos los TDS por la posible adquisición de diversos virus, como son el de inmunodeficiencia humana $(\mathrm{VIH})$, la hepatitis B (VHB) y la hepatitis $\mathrm{C}(\mathrm{VHC}){ }^{4}$

Por ejemplo, en el espacio clínico

...el trabajador pediatra que brinda la atención está expuesto a sufrir una lesión (pinchazo) con una aguja calibre 18, la cual contiene sangre del paciente, el cual sigue tratamiento antirretroviral, o bien el médico cirujano que por alguna razón sufre un accidente cortante con la hoja del bisturí al operar a un paciente con hepatitis B o hepatitis $\mathrm{C}$. O tal vez aquel médico que está intubando a un paciente en la sala de urgencias y, por lo prioritario del caso, no utiliza cubrebocas y el paciente tose y posteriormente se sabe que sufre una infección meningocócica. ${ }^{5}$

3 Coria Lorenzo, J. J. et al., "Accidentes con objetos punzocortantes y líquidos potencialmente infecciosos en personal de la salud que trabaja en un hospital de tercer nivel: análisis de 11 años", Perinatología y Reproducción Humana, México, vol. 29, núm. 2, junio de 2015, pp. 70-75, disponible en: http://wrwre. sciencedirect.com/science/article/pii/S0187533715000163.

4 Coria Lorenzo, J. J. y Pérez Robles, V. M. (eds.), Manual sobre el abordaje y recomendaciones epidemiológicas de enfermedades infecciosas urgentes y de notificación inmediata, México, Prado, 2014.

5 Coria Lorenzo, J. J., op. cit. 
Este libro forma parte del acervo de la Biblioteca Jurídica Virtual del Instituto de Investigaciones Jurídicas de la UNAM

Por otro lado, en cuestiones de bioseguridad en los laboratorios, en el ámbito internacional contamos con el Manual de bioseguridad en el laboratorio, de la Organización Mundial de la Salud (OMS) de 1982, en su tercera edición de 2005, el cual establece las directrices en materia de bioseguridad, códigos de práctica en laboratorio, vigilancia y manipulación de desechos, material de seguridad, procedimientos de transporte de sustancias microbiológicas y tóxicas, además de los peligros y riesgos de exposición a sustancias químicas, incluyendo explosivos. Asimismo, dicho manual establece, de manera importante, la formación y capacitación en materia de seguridad para el personal, además del establecimiento de comités de bioseguridad para la vigilancia y protección del personal. ${ }^{6}$

Dicho instrumento prevé diferencias entre conceptos, por ejemplo, entre seguridad biológica y protección biológica, con la finalidad de hacer hincapié en los requerimientos que deberán tener los laboratorios, además del uso de "prácticas microbiológicas correctas, el equipo de contención apropiado, el diseño, la operación y el mantenimiento de las instalaciones, y los aspectos administrativos para reducir al mínimo el riesgo de lesiones o enfermedades entre el personal".

Asimismo, es necesario realizar las siguientes precisiones conceptuales de acuerdo al manual, donde se establece que "seguridad biológica o bioseguridad" es el término utilizado para referirse a los principios, técnicas y prácticas aplicadas con el fin de evitar la exposición no intencional a patógenos y toxinas, o su liberación accidental. En cambio, la "protección biológica o bioprotección" se refiere a las medidas de protección de la institución y del personal destinadas a reducir el riesgo de pérdida, robo, uso incorrecto, desviaciones o liberación intencional de patógenos o toxinas. $^{7}$

6 Organización Mundial de la Salud, Manual de bioseguridad en el laboratorio, Ginebra, 2005.

7 Ibidem, p. 49. 
Este libro forma parte del acervo de la Biblioteca Jurídica Virtual del Instituto de Investigaciones Jurídicas de la UNAM

Para efectos de esta discusión dejaremos para otra ocasión el análisis de la bioseguridad en el laboratorio y nos enfocaremos a lo que se ha detectado en México como los riesgos biológicos más recurrentes para los TDS, como son las lesiones por pinchazo con agujas. Exploraremos las medidas de protección, seguridad y normativa existentes en relación con las pinchaduras con instrumentos punzocortantes en el ámbito de los TDS desde el panorama internacional para aterrizarlo al contexto nacional.

Desafortunadamente, hay una gran opacidad sobre los dispositivos médicos que se adquieren por el sector salud. No se ha registrado cuáles son las medidas de seguridad con las que cuenta el material punzocortante, o bien, los instrumentos para transfusión sanguínea, trasplantes e inyección de células troncales, por ejemplo, las hematopoyéticas. La transfusión o trasplante de células troncales hematopoyéticas se ha convertido en un tratamiento efectivo para tratar a pacientes pediátricos que sufren enfermedades de la sangre, como lo es la leucemia. Y el riesgo en este tipo de intervenciones radica en el aspirado de médula ósea (catéter periférico), aunque es el accidente que reporta menos sucesos.

Este tema ha sido de especial importancia y relevancia dentro del derecho comunitario de la Unión Europea, tan es así que, en julio de 2009, diferentes interlocutores sociales europeos firmaron el texto del Acuerdo marco para la prevención de las lesiones causadas por instrumentos cortantes y punzantes en el sector hospitalario y sanitario. En relación con lo anterior, se redactó una cláusula que busca que se observe el fomento o la consecución de uno de los objetivos de la política social respecto a la mejora de las condiciones laborales. En este acuerdo se observa una mezcla del enfoque de la seguridad social junto con el propósito de lograr un entorno de trabajo lo más seguro posible, la protección del personal sanitario y hospitalario del riesgo contra las lesiones causadas por cualquier instrumental sanitario cortopunzante, así como prevenir el riesgo de heridas e infecciones 
Este libro forma parte del acervo de la Biblioteca Jurídica Virtual del Instituto de Investigaciones Jurídicas de la UNAM

causadas por este tipo de instrumentos. Es un enfoque donde se integra la evaluación de riesgos y la prevención de los mismos, la debida formación e información y la inspección y vigilancia de los procedimientos de respuesta y seguimiento.

Esto sin dejar de considerar que la salud y seguridad de los trabajadores es fundamental y está estrechamente vinculada a la salud de los pacientes, lo que conformará la base de la calidad de los servicios prestados, y sin soslayar que se logre un lugar de trabajo lo más seguro posible con el uso y la práctica de los dispositivos de seguridad, tener medidas de planificación, información y formación. En el caso de España, por ejemplo, dicha regulación se aplica a todos los trabajadores del sector sanitario y hospitalario y a todos los que están bajo la dirección de los empresarios, así como a todos los establecimientos y servicios sanitarios tanto

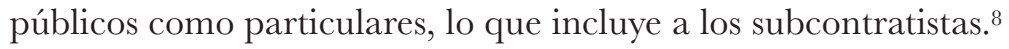

\section{GUÍAS INTERNACIONALES}

Una vez delimitado el ámbito de análisis y tomando en consideración la normativa internacional en materia de protección a la salud de los trabajadores como derecho humano, en efecto, en los diversos manuales, guías y estándares de buenas prácticas existentes, se admite que poco discutimos sobre la formación de los profesionales de la salud para evaluar, prevenir y evitar riesgos en el desarrollo de sus labores en las unidades hospitalarias.

En el 2015 la OMS emitió la guía para el uso de nuevas jeringas o agujas seguras "inteligentes" en las unidades de atención de la salud. ${ }^{9}$ La OMS asegura que la implementación de estas

8 Boletin Oficial del Estado, España, 31 de julio de 2013, disponible en: https: //wrwreboe.es/boe/dias/2013/07/31/pdfs/BOE-A-2013-8381.pdf.

9 World Health Organization, Guideline on the Use of Safety-Engineered Syringes for Intramuscular, Intradermal and Subcutaneous Injections in Health Care Settings, Ginebra, 2016, disponible en: http://wrwrw.who.int/injection_safety/global-campaign/injectionsafety_guidline.pdf? $u a=1$. 
Este libro forma parte del acervo de la Biblioteca Jurídica Virtual del Instituto de Investigaciones Jurídicas de la UNAM

jeringas desechables, que cuentan con mejores mecanismos de seguridad, podrían proteger a millones de TDS, puesto que están diseñadas para que no puedan usarse más de una vez. En suma, según la guía aducida, cada año, del 100\% de inyecciones que se aplican, alrededor del 5\% de éstas sirven para vacunar niños y adultos, $5 \%$ para transfusiones de sangre y anticonceptivos inyectables, mientras el 90\% restante se utiliza para administrar medicamentos. Lo anterior implica, también, las lesiones que se dan antes y después de un procedimiento médico, riesgo que no es menor y que, dicho sea de paso, es parte de toda esta cadena de potenciales riesgos profesionales.

La incorporación de las jeringas con tecnología segura impide su reutilización y además evita el riesgo de pinchaduras por parte del TDS, puesto que una vez utilizada la jeringa, una funda o cubierta protectora se desliza sobre la aguja impidiendo que el TDS pueda pincharse accidentalmente con la aguja, por tanto lo protege del riesgo de lesión biológica. Estos elementos tecnológicos de seguridad con que cuentan estas jeringas "inteligentes" resultan altamente eficaces en la reducción de riesgos biológicos en el ámbito clínico, y por consiguiente debería ser una prioridad su incorporación en las unidades clínicas de todos los países.

Aunque la OMS reconoce que el costo de estas nuevas jeringas constituye el doble de las que no están equipadas con mecanismos de seguridad, su precio podría disminuir en la medida que aumente la demanda como una situación convencional.

Sin olvidar el derecho de la Unión Europea, que prevé al HOSPEEM (European Hospital and Healthcare Employers' Association/Asociación Europea de los Empresarios del Sector Hospitalario y Sanitario) y a la EPSU (European Public Services Union/Federación Sindical Europea de los Servicios Públicos) como las entidades interlocutoras sociales europeas del sector hospitalario y sanitario, que se guían por los siguientes principios: personal de salud adecuadamente capacitado con los recursos adecuados; énfasis en la prevención de accidentes, las medias 
Este libro forma parte del acervo de la Biblioteca Jurídica Virtual del Instituto de Investigaciones Jurídicas de la UNAM

de cuidado de riesgos, cuidar de los factores laborales como los psicosociales y la organización del trabajo, políticas y prácticas de seguridad y salud; nunca se debe suponer que no existe un riesgo; identificar los equipos que representen un riesgo en el ejercicio médico; identificar los procesos de formación y sensibilización; consulta de las leyes relativas, así como de los convenios colectivos nacionales; las obligaciones se entienden como compartidas entre los trabajadores y los empleadores; tener lugares de trabajo planeados y con permanente supervisión; promover la cultura "sin culpa", ya que se deben ver errores sistémicos más que errores de un individuo. ${ }^{10}$

Por lo tanto, a nivel multilateral, según lo que señala la OMS, el entorno de trabajo saludable es aquel en el que los trabajadores y empleadores colaboran en un proceso de mejora continua para promover y proteger la salud, la seguridad y el bienestar de los trabajadores y la sustentabilidad del ambiente de trabajo con base en las siguientes aristas: la salud y la seguridad concernientes al ambiente físico de trabajo, al medio psicosocial y a los recursos de salud personales en el ambiente de trabajo. ${ }^{11}$

\section{PREVAlencia De Lesiones POR RIESGOS BiOlÓGICOS (PUNCIONES O PINCHAZOS ACGIDENTALES) DE LOS TRABAJADORES DE LA SALUD EN MÉXICO}

En México la literatura médica también reporta como preocupación los pocos reportes epidemiológicos de lesiones biológicas sufridas por heridas con material punzocortante en los TDS. ${ }^{12} \mathrm{La}$

10 Diario Oficial de la Unión Europea, julio de 2009.

11 World Health Organization, Entornos laborales saludables: fundamentos y modelo de la OMS. Contextualización, prácticas y literatura de apoyo, Ginebra, 2010, p. 110, disponible en: http://wrww.who.int/occupational_health/evelyn_hwp_spanish.pdf.

12 Barroso Aguirre, J. et al., "Heridas con material punzocortante en un instituto nacional de salud de México", Perinatología y Reproducción Humana, México, vol. 23, núm. 3, julio-septiembre de 2009, pp. 141-149. 
Este libro forma parte del acervo de la Biblioteca Jurídica Virtual del Instituto de Investigaciones Jurídicas de la UNAM

OMS ha afirmado que existen más de 2 millones de accidentes con instrumentos punzocortantes sufridos por trabajadores del sector salud, sin embargo, señala que existe un subregistro, por tanto, la cifra podría constituir el doble.

Aunque en nuestro país existen desde hace varios años programas de vigilancia de accidentes en TDS, siguen siendo pocas las unidades clínicas que cuentan con estos programas, y además, también se debe hacer alusión a un subregistro de las heridas por objetos punzocortantes en TDS. ${ }^{13}$

Cabe señalar que el Instituto Nacional de Ciencias Médicas y Nutrición "Salvador Zubirán”, desde el año 1987 cuenta con este programa. De esta manera, en diecisiete años se reportaron 1,641 accidentes, de los cuales 1,160 (70.7\%) fueron pinchaduras, 272 $(16.6 \%)$ salpicaduras y $209(2.7 \%)$ cortaduras. Los TDS que más accidentes comunicaron fueron las enfermeras (415, 25.3\%), de ahí los internos de pregrado (391, 23.8\%), afanadores (234, 14.3\%) y médicos $(155,9.4 \%)$. Así pues, el mecanismo de exposición más recurrente fue el de tomar muestras, seguido de pinchaduras fuera del contenedor y durante procedimientos quirúrgicos. ${ }^{14}$

De igual forma, los reportes presentados por el Hospital Infantil de México "Federico Gómez", de 1991 hasta el 2004, y por el Instituto Nacional de Perinatología, de 2005 a 2007, reportaron accidentes en TDS, mismos que se clasificaron, en su mayoría, en punciones de aguja, y de igual manera, reportados principalmente por personal de enfermería y médicos residentes. ${ }^{15}$

En su más reciente estudio, en el hospital de tercer nivel de atención, Hospital Infantil de México "Federico Gómez", mencionado antes, se recabaron datos de 2003 a diciembre de 2013 a través de la revisión de los formatos de accidente laboral siguiendo la metodología recomendada por la Asociación Americana de

13 Gopar Nieto, R. et al., "Panorama de heridas por objetos punzocortantes en trabajadores intrahospitalarios", Revista Médica del Instituto Mexicano del Seguro Social, México, núm. 53, 2015, pp. 356-361.

14 Coria Lorenzo, J. J., op. cit.

15 Idem. 
Este libro forma parte del acervo de la Biblioteca Jurídica Virtual del Instituto de Investigaciones Jurídicas de la UNAM

Hospitales; es decir, se recabó y se analizó el número de casos ocurridos por año, la frecuencia anual ocurrida con base al número de egresos, así como las tasas anuales con base a 100 camas y su relación por 1,000 egresos. ${ }^{16} \mathrm{El}$ resultado obtenido fue que en esos once años de estudio se reportaron 265 accidentes/100 camas y de 11.1/1,000 pacientes; ocupando el primer lugar los accidentes por objetos punzocortantes. Aquí reconocen que, aunque los accidentes laborales han descendido en la última década, no debe soslayarse que deben disminuirse al mínimo. En resumidas cuentas, no se tiene suficiente capacitación en cuanto a la actuación de los TSD, y en muchas ocasiones no se tienen los dispositivos de seguridad en el material clínico.

Otro estudio, proveniente de la Facultad de Medicina de la UNAM y elaborado por investigadores de la Facultad de Medicina de San Luis Potosí, da cuenta de que también existe alta prevalencia de punciones accidentales y riesgos asociados por actos inseguros en el uso de jeringas/agujas por parte de los médicos residentes y estudiantes de pregrado. ${ }^{17}$ En el estudio aludido se aplicaron 441 cuestionarios a médicos en formación y de posgrado (residentes) de esa Facultad (se utilizó una metodología similar a la aplicada por la Escuela de Medicina de George Washington, en el Distrito de Columbia, y Johns Hopkins, en Baltimore, Maryland, protocolo aprobado por el Comité de Bioética de Investigación de la UNAM). De esas actividades se advirtió que el 56.7\% de los participantes afirmaron haber sufrido al menos una punción por agujas hipodérmicas y de sutura, de las cuales sólo fueron reportadas el 44.5\%. Dichos incidentes se presentaron, en su mayoría, en el área de Medicina Interna, Ginecología y Obstetricia, Cirugía y Urgencias durante el turno nocturno. Por esta razón se conduce a reafir-

16 Idem.

17 Padrón Salas, Aldanely et al., "Prevalencia, condiciones y actos inseguros asociados a punciones accidentales de médicos en formación", Gaceta Médica de México, México, vol. 150, supl. 3, 2014, pp. 347-357, disponible en: http://wrwe. medigraphic.com/pdfs/gaceta/gm-2014/gms143m.pdf. 
Este libro forma parte del acervo de la Biblioteca Jurídica Virtual del Instituto de Investigaciones Jurídicas de la UNAM

mar la suposición de la OMS de que existe un subregistro de los casos de lesiones por punción en los hospitales, especialmente de los médicos en formación.

Entre los factores que reportaron como causa de dichas punciones destacan: la diferencia de género - en hombres punciones de tres o más y en mujeres sólo riesgo para la primera punción-, la fatiga, cursar el tercer año de la carrera, así como la guardia nocturna y el sentimiento de presión. Esos factores deberían ser tomados en cuenta para el análisis de riesgo al que están expuestos los TDS, puesto que al encontrarse los estudiantes en un nivel jerárquico inferior provoca la falta de reporte para no ser segregados por impericia. Ese contexto o ambiente coloca a los estudiantes en una situación de alto o mayor riesgo que el resto de los TDS de contraer alguna enfermedad transmisible (VIH, VHB, VHC). Ya que los estudiantes en formación no son TDS - contrario a los médicos en formación de posgrado (residentes), quienes, de acuerdo con la Ley Federal del Trabajo en el ámbito de adiestramiento, sí tienen una relación laboral-, por lo que dicha situación no los debe dejar ajenos a la protección adecuada de la salud, además de la prevención de riesgos, seguimiento y tratamiento oportuno de lesiones biológicas causadas por punciones accidentales. ${ }^{18}$

Derivado de la literatura médica podemos inferir que los estudiantes de pregrado, médicos residentes y el profesional de la enfermería son los servidores de la salud más afectados por el uso de jeringas poco seguras y, en general, de objetos punzocortantes. ${ }^{19}$ Las instituciones de salud encargadas de establecer comités de biovigilancia y medidas de bioseguridad podrían tener mejores medidas de capacitación y acompañamiento para reducir los riesgos por piquetes con agujas.

\section{Idem.}

19 Carreño J., Deyanira et al., "Conocimiento del personal médico sobre el manejo de punzocortantes", Ciencia UANL, México, año XVIII, núm. 73, mayojunio de 2015, disponible en: http://cienciauanl.uanl.mx/?p=4203. 
Este libro forma parte del acervo de la Biblioteca Jurídica Virtual del Instituto de Investigaciones Jurídicas de la UNAM

En Estados Unidos de América (EUA), después de la aprobación, en el año 2000, de la Ley de Seguridad y Prevención por Piquetes con Agujas Hipodérmicas, se obligó a los hospitales a reconstruir procesos y estrategias preventivas con la adquisición de dispositivos libres de agujas, inyecciones seguras y contenedores de objetos punzocortantes. Esto con la finalidad de disminuir el riesgo ocupacional por pinchadura de los TDS. Iguales medidas han sido adoptadas por la directiva en la materia de la Unión Europea, y su aplicación en la legislación local, como es el caso de España e Inglaterra. En América Latina, Brasil ha modificado también la normativa relativa a la seguridad en el control de riesgo y prevención de accidentes por punciones con agujas.

En el caso brasileño, en la NR32 (Norma Reglamentaria No. 32. Seguridad y Salud en el Trabajo en Servicios de Salud) se contemplan los riesgos biológicos, el programa de prevención de riesgos ambientales, el programa de control médico de salud ocupacional, materiales con dispositivos de seguridad, riesgos químicos y medidas de prevención de riesgos ambientales, radiaciones ionizantes, comidas, lavanderías, conservación y limpieza.

\section{ESQUEMA NAGIONAL NORMATIVO DE RIESGO \\ DE TRABAJO Y SALUD OCUPACIONAL \\ DE LOS TRABAJADORES DE LA SALUD}

En el apartado introductorio establecimos que la protección de la salud y seguridad del trabajador es un derecho humano previsto en nuestra carta magna. La garantía y protección del mismo derecho para los trabajadores de la salud se encuentra establecida en sus ordenamientos secundarios, mismos que son la Ley General de Salud (LGS) y la Ley Federal del Trabajo (LFT). ${ }^{20}$ A continuación nos referiremos a éstos y otros instrumentos normativos relevantes en la materia que nos ocupa.

20 Hernández, María del Pilar, Derechos del personal de la salud, México, UNAM, 2000 . 
Este libro forma parte del acervo de la Biblioteca Jurídica Virtual del Instituto de Investigaciones Jurídicas de la UNAM

\section{Riesgos de trabajo (Ley Federal del Trabajo)}

Para la OIT la salud en el trabajo es "la protección de las vidas y el bienestar físico de los trabajadores mediante la eliminación o control de los riesgos en el ambiente de trabajo o en el sistema de trabajo en el que operan los trabajadores".

Por otro lado, el Manual de bioseguridad en el laboratorio de la OMS establece que los niveles de bioseguridad se basarán en la evaluación del riesgo para proporcionar el mayor grado de protección y seguridad al personal de la salud. ${ }^{21}$

De esta manera se infiere que el control y, en la medida de lo posible, la eliminación de los riesgos en el entorno laboral, se vuelve vital. Por tanto, la evaluación, detección y definición de los riesgos es crucial para la protección de los TDS.

La LFT, en su artículo 473, define los riesgos de trabajo como "las acciones y enfermedades a los que están expuestos los trabajadores en ejercicio o con motivo de su trabajo". Por lo que los riesgos constituyen tanto los accidentes como las enfermedades de trabajo (no existe definición o tabla de evaluación de riesgos).

Por su parte, el numeral 474 de la LFT prevé como accidentes de trabajo

...toda lesión orgánica o perturbación funcional, inmediata o posterior, o la muerte producida repentinamente en ejercicio o con motivo del trabajo, cualesquiera que sean el lugar y el tiempo en los que se presente. Quedan incluidos en la definición anterior los accidentes que se produzcan al trasladarse el trabajador directamente de su domicilio al lugar de trabajo y de éste a aquél.

Luego, el precepto 475 de esa misma ley, señala que la enfermedad de trabajo es "todo estado patológico derivado de la acción continuada de una causa que tenga su origen o motivo en el trabajo o en el medio en que el trabajador se vea obligado a prestar sus servicios".

21 Organización Mundial de la Salud, op. cit. 
Este libro forma parte del acervo de la Biblioteca Jurídica Virtual del Instituto de Investigaciones Jurídicas de la UNAM

Consecuentemente, el artículo 519 establece que las acciones de los trabajadores y sus beneficiarios para reclamar pago por accidentes y enfermedades en el trabajo prescriben en dos años. Entonces ¿qué sucede con las enfermedades que se manifiestan después de ese tiempo? De esa pregunta nacería como propuesta de definición de riesgo "toda posibilidad de producción de accidentes y enfermedades de trabajo, así como factores presentes en el ambiente laboral que pueden ocasionarlos". ${ }^{22}$

El 21 de enero de 1997 fue publicado en el Diario Oficial de la Federación $(D O F)$ el Reglamento Federal de Seguridad, Higiene y Medio Ambiente de Trabajo, donde se establecieron las medidas de prevención de accidentes y enfermedades de trabajo conforme a lo dispuesto por la LFT. Su aplicación corresponde tanto a la Secretaría del Trabajo y Previsión Social como a las autoridades de los estados de la República integrantes de la nación, en sus respectivos ámbitos de competencia. ${ }^{23}$

Así pues, en este rubro los grupos que están en riesgo de contaminar sus cuerpos son los alumnos de las facultades de Medicina y de Odontología, de las escuelas de enfermería y de otros centros de formación de profesionales, ya que, al no ser trabajadores según la norma laboral, no tienen derecho a una indemnización por los riesgos profesionales ni a seguro social.

\section{Salud ocupacional}

\section{(Ley General de Salud)}

En cuestión de riesgos de afectación a la salud mental, existen estudios interesantes acerca de las alteraciones neuropsicológicas por la exposición crónica a bajas concentraciones de monóxido de carbono en trabajadores de autopista de peaje en México; la

22 Trejo Sánchez, Karina, "Por la salud ocupacional, una propuesta de reformas a la Ley Federal del Trabajo", El Cotidiano, México, núm. 178, marzo-abril de 2013, pp. 53-60, disponible en: http://wrew.redalyc.org/articulo.oa?id=32527006008.

23 Idem. 
Este libro forma parte del acervo de la Biblioteca Jurídica Virtual del Instituto de Investigaciones Jurídicas de la UNAM

exposición no es vigilada en nuestro país, a diferencia de EUA, donde es altamente regulada y verificada. ${ }^{24}$

De la actual legislación escapan otro tipo de riesgos que también están relacionados con la actividad clínica, por ejemplo, el desarrollo de trastornos psíquicos, psicosomáticos y de fatiga por las excesivas jornadas de trabajo, doble turno, rotación y trabajo nocturno, sobre todo de los médicos residentes y estudiantes de pregrado en las unidades hospitalarias de enseñanza.

Consecuentemente, se puede hablar de precauciones universales denominadas "medidas preventivas", como las normas de higiene personal, elementos de protección de barrera, como el uso de guantes, tener extrema precaución con el manejo de los objetos punzocortantes, así como la aplicación de vacunas que sean necesarias para el personal de salud.

\section{Legislación en salud}

De acuerdo con la LGS en nuestro país las unidades de prestación de servicios de salud deberán contar con departamentos de salud en el trabajo y están obligadas a tener un comité de bioseguridad y/o biovigilancia, mismos que estarán sujetos a las reglas que establezca el Centro Nacional de Transfusión Sanguínea para la elaboración de programas y gestión de riesgos biológicos por parte de los TDS cuando se trate del manejo de sangre.

Derivadas de la LGS encontramos las normativas relativas a la prevención de riesgos y salud ocupacional, establecidas en diversos ordenamientos, reglamentos y normas oficiales aplicables, como son la Ley General para la Prevención y Gestión Integral de Residuos Peligrosos, así como su reglamento, o sea,

24 Díaz López, Luis Fernando et al., "Alteraciones neuropsicológicas por exposición crónica a concentraciones bajas de monóxido de carbono en trabajadores de autopista de peaje de México", Salud Mental, México, vol. 38, núm. 5, septiembre-octubre de 2015, pp. 353-359. 
Este libro forma parte del acervo de la Biblioteca Jurídica Virtual del Instituto de Investigaciones Jurídicas de la UNAM

no dejar de conocer y ubicar a las empresas autorizadas para el manejo de residuos peligrosos.

En cuanto a los sistemas de seguridad social, nuestro país cuenta con tres - sin olvidar que existen otros-: Ley del Instituto Mexicano del Seguro Social, Ley del Instituto de Seguridad y Servicios Sociales para los Trabajadores del Estado y la Ley del Instituto de Seguridad Social para las Fuerzas Armadas Mexicanas, que son la piedra angular, junto con el artículo 123 constitucional, de los servicios sociales de salud para todo nuestro país.

A causa de lo anterior es que podemos analizar y estudiar otro aspecto de los trabajadores que prestan sus servicios para el sector salud, mismos que, por razón de sus funciones, ponen en peligro su salud, e incluso su vida.

\section{Norma Oficial Mexicana y guías nacionales para la evaluación,} reducción y prevención de riesgos biológicos

De acuerdo con la Norma Oficial Mexicana (NOM) NOM087-EGOL-SSA1-2002 (Protección ambiental-Salud ambientalResiduos peligrosos biológico/infecciosos-Clasificación y especificaciones de manejo), los residuos peligrosos punzocortantes y líquidos deberán depositarse en recipientes especiales para punzocortantes, de polipropileno color rojo, con un contenido de metales pesados de no más de una parte por millón $(<1 \mathrm{ppm})$ y libres de cloro, que permitan verificar el volumen ocupado en el mismo, resistentes a fracturas y pérdidas de contenido al caerse, destructibles por métodos físicos, los cuales deben tener un separador de agujas con abertura para su depósito, con tapa de ensamble seguro y cierre permanente; deberán, asimismo, contar con la leyenda "Residuos peligrosos punzocortantes biológicoinfecciosos" e identificarse con el símbolo universal de riesgo biológico. Los recipientes para tales residuos se llenarán hasta el 80\% de su capacidad, asegurándose los dispositivos de cierre, y 
Este libro forma parte del acervo de la Biblioteca Jurídica Virtual del Instituto de Investigaciones Jurídicas de la UNAM

no deberán abrirse o vaciarse - un tópico muy relacionado con lo que en materia de comercio internacional se llama "barreras técnicas al comercio"-.

Aun cuando se conoce esta norma oficial por parte de los TDS, las enfermeras y enfermeros, así como los médicos residentes, se encuentran en dobles jornadas de trabajo y guardias nocturnas que provocan fatigas, mismas que los exponen a mayor riesgo de sufrir accidentes por la inadecuada eliminación de objetos punzocortantes, que pueden ser lanzados a la basura común, provocando riesgo también para los trabajadores de intendencia. En el 2015 investigadores de la Universidad Autónoma de Nuevo León llevaron a cabo investigación empírica entre TDS, en específico, profesionales de enfermería del Hospital General de Zona No. 2, en Monterrey, Nuevo León. Se aplicaron 208 encuestas sobre el conocimiento de la norma mencionada y los resultados que arrojó la muestra en estudio revelaron que la mitad de los TDS encuestados desconocían las técnicas elementales del manejo y disposición adecuados del material y residuos peligrosos punzocortantes que establece la norma. Sin embargo, la mayoría afirma tener conocimiento sobre el uso y desecho de los mismos sin necesidad de conocer con exactitud la norma. ${ }^{25}$

Similar estudio se llevó a cabo con cien TDS (personal de enfermería), sobre la percepción del riesgo biológico y el conocimiento y aplicación de las normas relevantes en un hospital de seguridad social del norte de Veracruz, teniendo como resultado que el 90\% de los TDS encuestados desconocía los protocolos y los programas post exposición a accidentes. ${ }^{26}$

Un dato que llama la atención es que en la literatura se ha reportado y sugerido la manera de prevención y disminución de riesgos; es decir, el conocimiento del manejo cuidadoso de jerin-

25 Carreño J., Deyanira, op. cit.

26 Fang Huerta, María de los Ángeles et al., "Percepción del personal de enfermería sobre los riesgos biológicos", Revista Conamed, México, vol. 20, núm. 1, enero-marzo de 2015, pp. 12-16, disponible en: http://wrwedgdi-conamed.salud. gob.mx/ojs-conamed/index.php/revconamed/article/view/47/118. 
Este libro forma parte del acervo de la Biblioteca Jurídica Virtual del Instituto de Investigaciones Jurídicas de la UNAM

gas peligrosas, por tanto, el uso de doble guante en cirugía, especialmente en pacientes portadores de enfermedades infecciosas trasmisibles por pinchaduras. Además, se reconoce la existencia en el mercado de nuevas jeringas y dispositivos con agujas retráctiles que después de utilizarse dejan de estar expuestas, haciendo prácticamente imposible la posibilidad de accidentes, aunque no se cuenta con ellos en la mayoría de las unidades clínicas, puesto que estos dispositivos son altamente costosos. ${ }^{27}$

Una vez que detallamos lo anterior, y que hemos descrito de manera lacónica el peligro para la salud humana de los residuos peligrosos hospitalarios, nos preguntamos: ¿no será más costoso poner en peligro la vida de los TDS y la seguridad de todos los que intervienen en la atención clínica, aunado al grave problema de salud pública que podría ocasionar?

Asimismo, no deben de dejar de observarse en la práctica médica la Guía para el manejo de los residuos peligrosos biológico-infecciosos en unidades de salud ni la Guía de práctica clínica IMSS-241-12. Prevención, diagnóstico y tratamiento de la exposición laboral al VIH en trabajadores de la salud.

Otros instrumentos administrativos que sirven de referencia en cuanto a las normas de seguridad e higiene en los centros de trabajo de salubridad son las normas mexicanas: NMX-A-038/1-INNTEX-2011 Industria del vestido-vestuario para instituciones del sector salud-Parte 1-Filipinas y conjunto de filipina con pantalón y accesorios, para uso hospitalario o médico-administrativo-especificaciones; NMX-E-235-CNCP-2009 Industria del plástico-bolsas de polietileno para uso en aseo, aplicaciones generales, guarderías, así como nutrición y dietética, que se utilizan en el sector salud-especificaciones y métodos de prueba (cancela a las NMX-E235-SCFI-2001, NMX-E-236-SCFI-2; NMX-E-235-CNCP-2015 Industria del plástico-Bolsas de polietileno para uso en aseo, aplica-

27 Rangel Frausto, Sigfrido et al., "Prevención de la infección de la exposición a VIH", Revista de Investigación Clínica, México, vol. 56, núm. 2, abril de 2004, pp. 237-241, disponible en: http://wwre.scielo.org. $m x /$ scielo.php.script=sci_art textEpid $=$ S0034-83762004000200014\#c1. 
Este libro forma parte del acervo de la Biblioteca Jurídica Virtual del Instituto de Investigaciones Jurídicas de la UNAM

ciones generales, guarderías, así como nutrición y dietética, que se utilizan en el sector salud-Especificaciones y métodos de prueba/ cancela a la NMX-E-235-CNCP-2009); NMX-SAST-001-IMNC2008 Sistemas de gestión de seguridad y salud en el trabajo-Requisitos (cancela a la NMX-SAST-001-IMNG-2000); NMX-SAST002-IMNC-2001 Sistemas de administración de seguridad y salud en el trabajo-Guía para la implementación de NMX-SAST-001IMNC-2000; NMX-SAST-003-INMX-2004 Directrices para la competencia y evaluación de los auditores de sistemas de administración de seguridad y salud en el trabajo; PROY-NMX-CG-026IMNG-2008 Guía de interpretación de la norma NMX-CG9001-IMNG-2000 en servicios de salud, y PROY-NMX-SAST002-IMNC-2011 Sistema de seguridad y salud en el trabajo-Directrices para la implementación de la norma mexicana NMXSAST-001-IMNC-2008.

\section{REFLEXIÓN: ¿REGULACIÓN BASADA EN RIESGOS?}

La regulación no es suficiente si no se adecúa a los relativamente nuevos procesos y estrategias preventivas existentes; por ejemplo, en la adquisición de dispositivos libres de agujas, inyección segura y contenedores de objetos punzocortantes, esto con la finalidad de disminuir el riesgo ocupacional por pinchadura de los TDS. De sostenerse esa postura, se estaría en contra del derecho de protección a la salud. En este sentido, se negaría el vivir en estado óptimo de seguridad e higiene a todos los colaboradores médicos y de enfermería; es decir, tener la oportunidad de conservar su salud y su vida en situaciones extremas.

Con relación a los estudiantes de medicina en formación, la práctica clínica constituye un paso imprescindible para el desarrollo de habilidades y competencias para su futuro ingreso en la atención a la salud, por tanto, si no se realiza esta formación bajo las más altas condiciones de seguridad y con los dispositivos 
Este libro forma parte del acervo de la Biblioteca Jurídica Virtual del Instituto de Investigaciones Jurídicas de la UNAM

tecnológicos más avanzados que garanticen la disminución de riesgo, podría causar un grave problema de salud.

La falta de reportes o de comunicación de pinchaduras por parte de los médicos residentes y estudiantes de pregrado también refleja una falla en el sistema de formación médica y los procesos jerárquicos y de vigilancia, lo cual afecta no sólo en el aumento del riesgo y prevalencia de lesiones biológicas por patógenos como el VIH, el VHB y el VHC, sin dejar de lado las alteraciones psicosomáticas en detrimento de la salud mental.

La efectiva comunicación entre los TDS es esencial para establecer nuevos mecanismos y procesos para la atención post pinchadura. De esta manera se eliminarían otros elementos de inhibición de la comunicación, por ejemplo, el impacto social (estigmatización y discriminación). Se debe favorecer la cultura del reporte y la integración de agujas seguras para todos los TDS involucrados en la atención clínica, incluyendo a los estudiantes de pregrado.

Se ha demostrado en otras experiencias regulatorias, como son las de EUA, Brasil (NR32, 2011), directivas de la Unión Europea, España e Inglaterra, que la incorporación de nuevos mecanismos de control, como dispositivos más seguros, han reducido accidentes ocupacionales, y con ello, el riesgo y las lesiones biológicas, en particular con la adquisición de las llamadas jeringas o agujas "inteligentes". ${ }^{28}$

El Estado mexicano está obligado a adoptar medidas exhaustivas para la máxima protección y disminución de riesgos biológicos para los TDS. La implementación de mayor capacitación y vigilancia específica podría coadyuvar al trabajo de los órganos encargados de vigilar diversas áreas de riesgos sanitarios (Comisión Federal para la Protección Contra Riesgos Sanitarios, Cofepris). De esta manera se podrá tener un mejor reporte y comuni-

28 Phillips, E. K. et al., "Issues in Understanding the Impact of the Needlestick Safety and Prevention Act on Hospital Sharps Injuries", Infection Control E Hospital Epidemiology, Cambridge, vol. 34, núm. 9, septiembre de 2013, pp. 935-939. 
Este libro forma parte del acervo de la Biblioteca Jurídica Virtual del Instituto de Investigaciones Jurídicas de la UNAM

cación de los incidentes derivados del uso de insumos peligrosos que deben ser retirados de las unidades clínicas, y por tanto, se podrán adquirir mejores dispositivos, agujas seguras (retráctilesinteligentes) y equipo de desecho de los mismos, para prevenir y disminuir de manera significativa los riesgos en la práctica clínica. De igual manera, se deberán promover las mejores prácticas en el uso, administración y desecho de estos artefactos. Consecuentemente, una adecuada disminución de riesgos biológicos para los TDS lo constituiría la adopción de mejores políticas sanitarias; vigilancia adecuada para el uso y eliminación de las jeringas reutilizables.

No obstante, estudios recientes también han demostrado que la inclusión de instrumentos más seguros en el ámbito clínico no es la única solución, puesto que, aunque se tenga la mejor tecnología, si no se sabe utilizar se corren los mismos riesgos - por ejemplo, si un dispositivo de seguridad no es activado, o se hace de manera errónea o incompleta, se tiene el mismo riesgo de sufrir un pinchazo - . Es decir, a la par de la adquisición de dispositivos con mayor tecnología, y por tanto, más seguros, se tendrán que implementar medidas más dinámicas con programas de capacitación y actualización permanentes respecto del uso de las nuevas tecnologías para todos los TDS.

La efectiva garantía de la protección a la salud de los TDS constituiría que la Secretaría de Salud ajustara sus criterios de adquisición de agujas "inteligentes" de acuerdo con las guías y estándares establecidos por la OMS, de esta manera se asegura la calidad y efectiva atención clínica, con prácticas seguras para los TDS y los pacientes. Pero a largo plazo constituye la eliminación de riesgos de propagación de enfermedades transmisibles para la población en general, evitando problemas de salud pública.

Del mismo modo, los hospitales y los centros de salud que no controlan la seguridad e higiene de cada usuario y de sus trabajadores va contra los fundamentos de su existencia. Por ello, el personal sanitario debe anticiparse a los peligros potenciales, para que todo el personal haga un esfuerzo continuo y 
Este libro forma parte del acervo de la Biblioteca Jurídica Virtual del Instituto de Investigaciones Jurídicas de la UNAM

organizado. Se puede actuar a diferentes niveles en los centros de trabajo de salud pública, como propiciando la eliminación o reducción de fuentes productoras nocivas para la salud, o la sustitución o mejora de los procesos y equipos para la protección personal de los trabajadores.

\section{FUENTES DE CONSULTA}

\section{Legislación}

Brasil, 2011, NR32, Norma Reglamentaria. Seguridad y salud en el trabajo en servicios de salud.

Declaración Universal de los Derechos Humanos (1948).

España, Ministerio de Empleo y Seguridad Social, Orden ESS/ 1451/2013, 29 de julio, Disposiciones para la prevención de lesiones causadas por instrumentos cortantes y punzantes en el sector sanitario hospitalario.

Estados Unidos de América, 2000, NSPA, Ley de seguridad y prevención por piquetes con agujas hipodérmicas.

Guía de práctica Clínica IMSS-241-12, Prevención, Diagnóstico y Tratamiento de la Exposición Laboral al VIH en Trabajadores de la Salud, disponible en: http://wrerw.cenetec.salud.gob.mx/descargas/gpc/ CatalogoMaestro/241_GPC_Exposicionlaboral/GRR_ExposicionLaboral.pdf (fecha de consulta: 24 de junio de 2016).

Guía para el manejo de los residuos peligrosos biológico infecciosos en unidades de salud, disponible en: http://wrere.promocion.salud.gob.mx/dgps/descar gas1/influenza/mat/Guia_manejo_de_residuos_biologicos.pdf.

Inglaterra, HSE (Health and Safety Executive), 2013, Health and Safety (Sharp Instruments in Healthcare), Regulations 2013, HMSO, London, England.

Normas Mexicanas en materia de salud, disponibles en: http:// wrere.economia-nmx.gob.mx/normasmx/consulta.nmx (fecha de consulta: 24 de junio de 2016). 
Este libro forma parte del acervo de la Biblioteca Jurídica Virtual del Instituto de Investigaciones Jurídicas de la UNAM

Secretaría de Medio Ambiente y Recursos Naturales, Norma Oficial Mexicana NOM-087-EGOL-SSA1-2002 Protección ambiental-Salud ambiental-Residuos peligrosos biológico-infecciosos-Clasificación y especificaciones de manejo, Diario Oficial de la Federación del 17 de febrero de 2003, disponible en: http:// wrere.economia-noms.gob.mx/normas/noms/2003/087ecol.pdf. Si se requiere su ficha de identificación véase: $h t t p: / / w w r e c c o n o m i a-$ noms.gob.mx/noms/detalleXNormaAction.do.

Unión Europea, Directiva 2010/32/UE del Consejo, 10 de mayo de 2010, Acuerdo marco para la prevención de las lesiones causadas por instrumentos cortantes y punzantes en el sector hospitalario y sanitario celebrado por HOSPEEM (European Hospital and Healthcare Employers' Association/Asociación Europea de los Empresarios del Sector Hospitalario y Sanitario) y la EPSU (European Federation of Public Services Unions/ Federación Sindical Europea de los Servicios Públicos).

\section{Bibliohemerografia}

Cano Valle, Fernando et al., Medicina y estructuras jurídico-administrativas en México. Hacia la reforma integral del sistema de salud mexicano, México, UNAM, Instituto de Investigaciones Jurídicas, 2014.

Secretaría de Medio Ambiente y Recursos Naturales (Semarnat), Empresas autorizadas para el manejo de residuos peligrosos, disponible en: http://wwre.semarnat.gob. $m x /$ transparencia/transparen cia-focalizada/residuos/empresas-autorizadas-para-el-manejo-de-resi duos. 
Este libro forma parte del acervo de la Biblioteca Jurídica Virtual del Instituto de Investigaciones Jurídicas de la UNAM

\title{
EL IMPACTO DE LA REGULACIÓN DEL MANEJO DEL RIESGO BIOLÓGICO EN LOS ESTADOS UNIDOS DE AMÉRICA
}

\section{Amber MitcheLL*}

\begin{abstract}
SUMARIO: I. Introducción. II. Relevancia de las intervenciones en la salud pública en los Estados Unidos de América. III. Evolución del tipo de lesiones.
\end{abstract}

\section{INTRODUCCIÓN}

Muchísimas gracias por la invitación para explicar a ustedes en este ensayo nuestra experiencia en los Estados Unidos de América (EUA) con respecto a las regulaciones sobre los riesgos biológicos y para la prevención de accidentes relacionados con enfermedades transmitidas por sangre. Me propongo cubrir específicamente las siguientes preguntas: ¿cómo son los riesgos a la salud en los EUA en comparación a como pueden ser en México?, y ¿cuál ha sido la experiencia con las regulaciones nacionales y federales para los trabajadores de la salud? Me propongo también explicar cómo se ha extendido esto por todo el mundo, para después referirme a algunos de nuestros datos actuales sobre la exposición ocupacional con respecto a riesgos biológicos en los EUA. Además, tengo algu-

\footnotetext{
* Presidenta y directora ejecutiva del International Safety Center. Experta en salud pública, seguridad en el trabajo en las instituciones de salud y temas de salud vinculados con enfermedades infecciosas. Este texto es producto de la versión estenográfica traducida y editada por personal del Instituto de Investigaciones Jurídicas de la UNAM.
} 
Este libro forma parte del acervo de la Biblioteca Jurídica Virtual del Instituto de Investigaciones Jurídicas de la UNAM

nas comparaciones interesantes referentes a cómo podrían ser las exposiciones para las enfermeras en relación con trabajadores de laboratorios médicos. Me referiré, igualmente, a las lecciones que hemos aprendido en todo este proceso.

\section{RELEVANGIA DE LAS INTERVENGIONES EN LA SALUD PÚBLICA EN LOS EsTADOS UNIDOS DE AMÉRICA}

En primer lugar, deseo aludir a algunos datos relativos a la expectativa de vida en los EUA desde 1900 hasta el año 2000. En general, se puede afirmar que en ese periodo ha habido, más o menos, un incremento de veinticinco años en la expectativa de vida de los americanos, y esto se debe a la introducción de políticas relacionadas con la seguridad. Es decir, el incremento de la expectativa de vida de los ciudadanos americanos se debe a intervenciones en la salud pública y a las reglamentaciones a las que me referiré enseguida.

Entre las razones por las que se ha incrementado la expectativa de vida en los EUA están el uso de vacunas, la existencia de lugares de trabajo seguros y una mejora en el control de las enfermedades infecciosas.

Las amenazas infecciosas y biológicas están más presentes que nunca, y mucha gente en el mundo se ve afectada por patógenos, algunos de ellos transmitidos específicamente por vía de la sangre. Existe toda una lista que se incluye en las normas de los EUA, relativa a los patógenos y enfermedades transmitidas por sangre; lista que sirve para mostrar que hay una gran cantidad de patógenos que representan riesgos ocupacionales para trabajadores de la salud. La hepatitis B, por ejemplo, es uno de los más extendidos: más de 250 millones de personas tienen una infección de hepatitis B. Por lo que en los EUA, y en muchos otros países, ahora se requiere la vacuna para esta enfermedad - en los EUA para todos los niños antes de que entren a la escuelacuando antes únicamente era para trabajadores del cuidado de la salud. 
Este libro forma parte del acervo de la Biblioteca Jurídica Virtual del Instituto de Investigaciones Jurídicas de la UNAM

Por otra parte, una gran preocupación hoy en día es la hepatitis C. Por ello, el Centro para el Control de Enfermedades de los EUA recientemente publicó algunas investigaciones según las cuales, entre 2010 y 2013, hubo un incremento en la prevalencia de ese virus. Las infecciones provocadas por el virus de la hepatitis $\mathrm{C}$ se incrementaron en un $150 \%$ y ha marcado a más de 2,000 americanos entre 2013 y 2014 . Aunque la reglamentación en los EUA es muy estricta, este es un patógeno extremadamente importante. También lo es el incremento del virus de inmunodeficiencia humana (VIH) y del síndrome de inmunodeficiencia adquirida (SIDA) relacionados con trabajadores de la salud. Ha habido un aumento de esta infección, pero también se debe a la forma en que se llevan los registros en los EUA, donde es uno de los patógenos transmitidos por sangre más importantes; 1.1 millones de personas en los EUA viven con VIH, de los cuales el $15 \%$ no ha sido diagnosticado.

Los riesgos biológicos por los diversos patógenos son muy importantes porque los trabajadores de la salud están en la línea de fuego respecto de las enfermedades actuales y de las enfermedades emergentes, como por ejemplo, el ébola, o bien, el zika. Además, cada vez se da mayor contagio de enfermedades transmitidas por la sangre y se ha incrementado la población de pacientes con dos o más infecciones.

Lo ideal para prevenir estas infecciones sería tener una vacuna universal, porque nunca sabemos a qué vamos a estar expuestos en instalaciones para el cuidado de la salud. Hay demasiados virus que emergen, reemergen y que exponen a los trabajadores de la salud, por ello es que se piensa en vacuna universal.

Ahora bien, toca referirnos al tema de las punciones provocadas por agujas de jeringas en los EUA. Lo que mencionaré sucedió en un hospital en el estado de Virginia. Se trata de un estudio que realizó la doctora Janine Jagger, quien a principios de los años ochenta del siglo pasado analizó qué dispositivos provocaron lesiones punzocortantes y qué estaban haciendo los trabajadores cuando sufrieron el accidente. Toda la información se puso en 
Este libro forma parte del acervo de la Biblioteca Jurídica Virtual del Instituto de Investigaciones Jurídicas de la UNAM

una gráfica muy sencilla con indicadores para poder averiguar cuáles son los dispositivos que provocaron lesiones con punzocortantes o por suministro intravenoso.

Posteriormente, en los noventa, el Centro para el Control de Enfermedades (CDC por sus siglas en inglés) y luego la Food and Drug Administration (FDA) de los EUA produjeron guías para prevenir la contaminación por sangre y punzocortantes. Además, hubo campañas del Instituto Nacional para la Prevención de Enfermedades en el lugar de trabajo. Cada una de estas agencias estaba poniendo más atención en este problema.

Hacia finales de la década de los noventa hubo un avance en la seguridad de dispositivos médicos; surgieron dispositivos que tenían una guarda exactamente en la punta o en su parte cortante. Hubo entonces, por ejemplo, escalpelos, agujas y lancetas más seguras. Estos son simplemente algunos ejemplos que podría mencionar, pero tenemos también agencias que están enfocadas en desarrollar políticas en paralelo con las compañías de dispositivos médicos que están fabricando dispositivos más seguros y sacándolos al mercado.

Ahora tenemos datos nacionales de las lesiones con punzocortantes, así como reportes estatales de estas lesiones. Toda esta información está disponible junto con gran cantidad de documentos escritos por expertos, centros académicos, asociaciones profesionales de trabajadores organizados, sindicatos, etcétera.

Por otra parte, algunos estados han aprobado su propia legislación para prevenir este tipo de accidentes, por ejemplo, California lo hizo en la década de los noventa, y también podemos mencionar, a nivel nacional, la Ley de Seguridad y Prevención de las Lesiones con Agujas, con el propósito de lograr ambientes más seguros para trabajadores de la salud. Esta fue una ley en los EUA que se aprobó unánimemente en el Congreso y se refiere a patógenos transmitidos por sangre, establece reglas sobre la seguridad de los dispositivos médicos y sobre indemnizaciones y otras sanciones por violación a las mismas. 
Este libro forma parte del acervo de la Biblioteca Jurídica Virtual del Instituto de Investigaciones Jurídicas de la UNAM

No obstante, además de la Ley de Seguridad y Prevención de las Lesiones con Agujas, en los EUA se requiere un plan para el control del riesgo, es decir, un plan por escrito que identifique cada uno de los riesgos relacionados con patógenos retransmitidos por sangre, así como el uso de dispositivos médicos con mecanismos de seguridad como parte de los instrumentos para mitigar el riesgo. Aunque también hay requerimientos para los trabajadores, por ejemplo, de utilizar guantes, cubrebocas, etcétera. Sin embargo, un nuevo requerimiento para el uso de las agujas de jeringa era que los trabajadores que se encuentran "en la línea de fuego" y que tengan que utilizar dispositivos punzocortantes, conozcan y decidan sobre el uso de estos dispositivos, pues no es algo que concierna sólo a la gerencia de las instituciones de salud: los trabajadores mismos deben tener participación en la decisión respecto a los dispositivos que se utilicen.

Por otro lado, se necesita mantener registros de todo lo que se refiere a enfermedades ocupacionales de los trabajadores de la salud y de las que debe estar consciente el patrón. Igualmente, hay un requerimiento de mantener una bitácora de lesiones por objetos punzocortantes. Además, existen requerimientos sobre capacitación en materia de seguridad para los trabajadores de la salud en los EUA; los trabajadores deben tomar una capacitación inicial cuando vienen a trabajar a un lugar especial, pero también requieren capacitación periódica sobre el uso de los dispositivos y las prácticas clínicas asociadas a este rubro.

En los EUA existen reglamentos muy claros respecto a cómo se debe manejar cualquier exposición. Hay, incluso, formatos de evaluación estándar que podrían utilizarse en instalaciones de salud sobre cómo seleccionar los dispositivos específicos, y existen, asimismo, formatos de evaluación para todos los dispositivos que se están utilizando. Se tienen así bitácoras de lesiones provocadas por objetos punzocortantes, que por razones de confidencialidad no tienen el número de empleado, sino que solamente se identifica al patrón. Únicamente se registra el incidente, para saber 
Este libro forma parte del acervo de la Biblioteca Jurídica Virtual del Instituto de Investigaciones Jurídicas de la UNAM

en qué consistió y qué era lo que rodeaba al trabajador cuando sucedió (lugar, fecha, etcétera).

\section{EVOLUCIÓN DEL TIPO DE LESIONES}

Ahora me referiré a la parte más interesante, es decir, a cómo han cambiado las lesiones conforme ha pasado el tiempo, porque hay lesiones que han disminuido en comparación con la disponibilidad en el mercado de los distintos dispositivos para la atención médica. La correlación es clara: al ser los dispositivos más seguros, disminuyen las lesiones. Esto es muy importante y llamativo desde el punto de vista económico, ya que la seguridad no sólo beneficia a los trabajadores de la salud, sino a la economía en general del país. Así, en los EUA el uso de dispositivos no seguros se ha reducido, mientras que usar dispositivos seguros es ya muy común. En cada categoría de jeringa estamos incrementando la seguridad gracias a la regulación que he mencionado. Así, vemos una caída, y con el tiempo, una clara disminución en las lesiones con objetos punzocortantes. Lo anterior vale también para las llamadas agujas de sutura; ha habido una disminución en las lesiones de sutura en comparación con el tiempo en que sólo se usaban agujas para sutura tradicionales. Con agujas de sutura seguras, disminuyen las lesiones, y esto realmente tiene sentido.

A continuación explicaré un poco acerca de otros elementos normativos y de regulación con los que ya contamos en los EUA; por ejemplo, la Occupational Safety and Health Administration (OSHA, y que en castellano se denominaría Administración para la Seguridad y Salud Ocupacional), donde inicié mi carrera como reguladora en el tema de las normas sobre enfermedades infecciosas. Otro ejemplo de lineamiento que tenemos, y que por supuesto se encuentra en una norma, es el que se refiere al equipo de protección personal que se utiliza para cualquier riesgo por exposición a elementos biológicos. 
Este libro forma parte del acervo de la Biblioteca Jurídica Virtual del Instituto de Investigaciones Jurídicas de la UNAM

Se pueden hacer comparaciones internacionales. Por mencionar sólo un ejemplo, la diferencia entre EUA y Zambia es enorme. En Zambia los patógenos transmitidos son muy extendidos y la cantidad de lesiones es gigantesca; no únicamente la población de personas infectadas por patógenos es muy alta, sino también el número de trabajadores de la salud lesionados. Es por eso que las políticas son tan importantes. Así se podría explicar por qué en Zambia la expansión de VIH, hepatitis B y hepatitis $\mathrm{C}$, en comparación, es tan grande.

Por último, ¿cómo se ven nuestros datos en este momento? En el International Safety Center recolectamos información sobre exposición de riesgos ocupacionales en hospitales en todo el mundo. Además, hay un agregado en los EUA formado con los datos que recolectamos todos los años, y estos datos sirven como una referencia a nivel nacional para que otros hospitales se comparen también.

Debo mencionar también la importancia de la red de información para prevención de exposiciones EPINet, que es un sistema que provee métodos estandarizados para registrar y dar seguimiento a lesiones cutáneas que implican contacto con fluidos sanguíneos. Este software se ha distribuido en todo el mundo - se ha traducido a veinticuatro idiomas y se proporciona de manera gratuita-, además, hemos hecho alianzas con empresas como Becton Dickinson para difundirlo. En los EUA hay una larga lista de hospitales que pueden proporcionar y contribuir con sus datos todo el año en el marco de ese sistema de información.

EPINet tiene dos tipos de reporte: uno para salpicaduras con sangre y otro para lesiones por agujas de jeringa y objetos punzocortantes. El reporte se basa en un cuestionario muy completo que se debe completar cuando ocurre una lesión. Por cada lesión debe haber un reporte; podría haber múltiples exposiciones, pero también podría darse una salpicadura por haberse usado un catéter, y podría haber una aguja y una salpicadura en el mismo incidente. O sea, a pesar de que se vea solamente un incidente, serían varias exposiciones, pero solamente un reporte por empleado. 
Este libro forma parte del acervo de la Biblioteca Jurídica Virtual del Instituto de Investigaciones Jurídicas de la UNAM

Así, EPINet registra cuándo pasa la lesión, sus características, cómo se maneja, ayuda a calcular el costo de la exposición y a identificar la sangre y luego la del trabajador, entre otras cosas.

La información actual de incidentes en EUA la hemos capturado basándonos en los censos diarios promedio respecto de las lesiones sufridas por los internados en camas, es decir, los pacientes. Pero la información actual no captura la de los trabajadores de la salud que atienden en urgencias, que es la población más grande que experimenta estas lesiones. Después, las lesiones con instrumentos punzocortantes se dan con más frecuencia en laboratorios.

En cuanto a las lesiones provenientes de los diferentes dispositivos, la mayoría ocurre por vía de agujas hipodérmicas y por agujas de suturas. La siguiente categoría que produce lesiones son los dispositivos para recolección de sangre. Hay que tener en cuenta que aunque en EUA a los trabajadores de la salud se les pide que utilicen los dispositivos de seguridad, la mitad recibe lesiones antes de activar el dispositivo de seguridad. Y todavía, relacionado con la recolección de sangre, tenemos un gran grupo de lesiones derivado de sacar la sangre con una jeringa desechable y luego pasarla a un tubo para enviar al laboratorio. Esta práctica no es tan frecuente en los EUA ya que es muy arriesgada, pero aun así sigue generando lesiones. Lo que sirve para recordar que estamos muy alejados de la perfección y tenemos mucho trabajo por realizar todavía.

Greo que una de las cosas más importantes relacionadas con los instrumentos punzocortantes se da cuando la lesión le ocurre no al usuario, sino a otra persona que desempeña sus actividades alrededor de los usuarios; por ejemplo, en la limpieza o en servicios de comida. Así, uno de los grupos de riesgo más grandes es el de las personas que tienen que manejar la basura. Lo importante a señalar es que cuando se establece la seguridad para proteger al usuario, también se está protegiendo a todos los demás que están relacionados.

Por otro lado, están los incidentes derivados de las salpicaduras de sangre, cuya población más afectada son las enfermeras, 
Este libro forma parte del acervo de la Biblioteca Jurídica Virtual del Instituto de Investigaciones Jurídicas de la UNAM

pues son ellas quienes están al lado de la cama, en urgencias, en quirófanos. Y pasa comúnmente por salpicaduras de toma de muestras de sangre. Este tema es el que más se apega a mi corazón, ya que he pasado más de seis años elaborando mi tesis doctoral sobre esto.

Se tienen cifras de que el $65.7 \%$ de salpicaduras pasan al ojo. Los ojos tienen una cantidad inmensa de vasos circulatorios, por ello el ojo es el peor lugar para recibir esas exposiciones. Entonces, más del 77\% se va al ojo o a la boca de la enfermera, y también pasa con guantes o traspasa el uniforme, por lo que toca la piel. A saber: tan sólo el 2.8\% del personal de salud en los EUA usa un equipo correcto y del modo correcto para evitar la exposición, aun con las reglamentaciones que hemos mencionado. Y la correlación que arrojan datos y estadísticas es clara: a mayor uso de sistemas de protección para cara y ojos, menor la exposición, y por tanto, menor el riesgo de contraer infecciones.

En los EUA hemos llevado a cabo un gran proceso y tenemos la posibilidad de llevar esta información y compartir esta experiencia con otros países. La política nacional en esta materia debería ser que distintos actores en salud se reúnan para colaborar, monitorear el progreso y medir las exposiciones a lo largo del tiempo. Esta colaboración es clave para determinar cuál es la tasa de éxito y qué progreso debemos de tener, considerando el hecho de que tenemos mucho que hacer para mejorar. Como este esfuerzo se está dando aquí en México también, hay lecciones que se pueden aprender de nuestros errores y así robustecer su capacidad de establecer mecanismos de protección y seguridad para los trabajadores, para que crezcan y tengan efectos positivos en sus sistemas de salud.

Las recomendaciones para el futuro: participar activamente en dinámicas como ésta; rastrear las exposiciones, hacer evaluaciones con este rastreo. El punto crítico e importante es que la seguridad de los trabajadores de la salud y de los pacientes se traduzca en un mejor servicio, más protegido, en un esquema que garantice que los trabajadores y patrones están seguros. 
Este libro forma parte del acervo de la Biblioteca Jurídica Virtual del Instituto de Investigaciones Jurídicas de la UNAM

\title{
PROTEGGIÓN DE LOS TRABAJADORES DE LA SALUD
}

\author{
Alfredo SÁNCHEZ CASTAÑEdA*
}

\begin{abstract}
SUMARIO: I. Introducción. II. ¿Quiénes son los trabajadores de la salud? III. ¿Qué se puede entender por riesgos biológicos? IV. La protección de los trabajadores de la salud a la luz de la legislación internacional. V. La protección de los trabajadores de la salud a la luz de la legislación nacional. VI. La realidad de los trabajadores de la salud: entre una protección formal y una desprotección concreta. VII. Anexo.
\end{abstract}

\section{INTRODUGCIÓN}

A nivel mundial se presentan 317 millones de accidentes de trabajo, y como consecuencia de ellos, dos millones de defunciones. En el ámbito nacional hay pocas estadísticas sobre accidentes y enfermedades de trabajo, pero encontramos aún menos información donde se encuentren involucrados profesionales del sector salud y/o respecto de los riesgos biológicos a los que se encuentran expuestos.

En el presente ensayo se busca señalar, en primer lugar, quiénes pueden ser considerados como trabajadores de la salud (II), qué se entiende por riesgo biológico (III) y cuál es el marco internacional (IV) y nacional (V) aplicable en materia de protección de los trabajadores de la salud, particularmente en lo que se refiere a riesgos biológicos.

* Doctor en Derecho del trabajo y de la seguridad social por la Université Paris II Panthéon-Assas e investigador en el Instituto de Investigaciones Jurídicas de la UNAM. 
Este libro forma parte del acervo de la Biblioteca Jurídica Virtual del Instituto de Investigaciones Jurídicas de la UNAM

En el ámbito nacional se debe distinguir la regulación que se decanta de la Constitución, ya que en la legislación secundaria se expresa en dos ordenamientos: por un lado, la Ley Federal del Trabajo (LFT), respecto de la cual la Secretaría del Trabajo y Previsión Social (STPS) desempeña un papel fundamental; y por otro, en la Ley General de Salud (LGS), respecto de la cual la Secretaría de Salud (SSa) desempeña a la par un papel importante.

Las dos ramificaciones legales que constituyen el marco jurídico de los trabajadores de la salud tienen interrelaciones en toda esta legislación. En el presente documento se abordará principalmente la regulación de naturaleza laboral, sin desconocer la legislación que se desprende del sector salud (véase anexo).

Los puntos anteriores van a permitir estar en condiciones de formular una serie de consideraciones con relación al sector salud en México, en donde se puede apreciar la existencia de trabajadores de la salud en el sector privado y público, destacando cómo en el sector público la calidad de la protección de la salud de sus trabajadores se encuentra en una situación de vulnerabilidad (VI).

\section{II. ¿QUIÉNES SON LOS TRABAJADORES DE LA SALUD?}

La Organización Internacional del Trabajo (OIT), en su Clasificación Internacional Uniforme de Ocupaciones (CIUO) de 2007, considera las siguientes ocupaciones relacionadas con los servicios de salud, las cuales, con el fin de mejorar la visibilidad estadística, se dividieron en dos subgrupos: a) profesionales de la salud, y b) profesionales de nivel medio de la salud.

a) Profesionales de la salud:

- Médicos.

- Médicos generales.

- Médicos especialistas.

- Profesionales de enfermería y partería.

- Profesionales de enfermería.

- Profesionales de partería. 
Este libro forma parte del acervo de la Biblioteca Jurídica Virtual del Instituto de Investigaciones Jurídicas de la UNAM

- Profesionales de medicina tradicional y alternativa.

- Practicantes paramédicos.

- Veterinarios.

- Otros profesionales de la salud.

- Dentistas.

- Farmacéuticos.

- Profesionales de la salud y la higiene laboral y ambiental.

- Fisioterapeutas.

- Dietistas y nutricionistas.

- Audiólogos y logopedas.

- Optometristas.

- Profesionales de la salud no clasificados bajo otros epígrafes.

b) Profesionales de nivel medio de la salud:

- Técnicos médicos y farmacéuticos.

- Técnicos en aparatos de diagnóstico y tratamiento médico.

- Técnicos de laboratorios médicos.

- Técnicos y asistentes farmacéuticos.

- Técnicos de prótesis médicas y dentales.

- Profesionales de nivel medio de enfermería y partería.

- Profesionales de nivel medio de enfermería.

- Profesionales de nivel medio de partería.

- Practicantes de medicina tradicional y alternativa.

- Técnicos y asistentes veterinarios.

- Otros profesionales de nivel medio de la salud.

- Dentistas auxiliares y ayudantes de odontología.

- Técnicos en documentación sanitaria.

- Trabajadores comunitarios de la salud.

- Técnicos en optometría y ópticos.

- Técnicos y asistentes fisioterapeutas.

- Practicantes y asistentes médicos.

- Inspectores de la salud laboral y medioambiental y afines.

- Ayudantes de ambulancias. 
Este libro forma parte del acervo de la Biblioteca Jurídica Virtual del Instituto de Investigaciones Jurídicas de la UNAM

- Profesionales de la salud de nivel medio no clasificados bajo otros epígrafes.

\section{III. ¿QUÉ SE PUEDE ENTENDER POR RIESGOS BIOLÓGICOS?}

Los trabajadores de la salud pueden estar expuestos a materiales y agentes biológicos, como son bacterias, plásmidos, virus, hongos, microplasmas y parásitos, así como a productos celulares, productos de animales y de animales de laboratorio e insectos. Del mismo modo, pueden estar expuestos a procedimientos con el ácido desoxirribonucleico (ADN). Dichos agentes biológicos se pueden encontrar en secreciones biológicas, como sangre, orina, saliva y vómito.

El riesgo biológico, en principio, se refiere a la exposición con agentes patógenos, pero puede incluir también:

- Reacciones alérgicas a plantas y animales.

- Reacciones a sustancias irritantes, alérgicas o tóxicas.

- Ataque de animales en el lugar de trabajo.

Las clínicas y los hospitales, incluyendo los laboratorios clínicos, biológicos y de bioinvestigación, son espacios en donde los trabajadores se encuentran expuestos a estos riesgos biológicos.

Es importante señalar que la SSa cuenta con lineamientos para la gestión del riesgo biológico, los cuales siguen el modelo de gestión del riesgo biológico promovido por la Organización Mundial de la Salud (OMS) y se guían a partir del trabajo del Comité Europeo de Normalización, CWA 15793:2011 "Laboratory Biorisk Management” (Gestión de riesgo biológico en el laboratorio).

\section{LA PROTEGCIÓN DE LOS TRABAJADORES DE LA SALUD A LA LUZ DE LA LEGISLACIÓN INTERNACIONAL}

Existen diversos convenios elaborados por la OIT que se dedican al tema de la salud y la seguridad en el trabajo, los cuales se 
Este libro forma parte del acervo de la Biblioteca Jurídica Virtual del Instituto de Investigaciones Jurídicas de la UNAM

pueden dividir en dos tipos: 1) Convenios generales, para ramas de actividad económica, y 2) Riesgos específicos, que se refieren exclusivamente a una profesión en particular.

\section{Convenios generales}

Se trata de aquellos instrumentos jurídicos que establecen principios fundamentales sobre seguridad y salud en el trabajo. Entre ellos encontramos los siguientes:

\section{A. Convenio 102 y Convenio 155}

Existen dos convenios que pueden mencionarse conjuntamente: el Convenio 102, que establece las normas mínimas en materia de seguridad social, y el Convenio 155, sobre seguridad y salud de los trabajadores, así como su protocolo del año 2002.

En materia de convenios internacionales de la OIT, el Convenio 102 (1952) merece una atención particular al tratarse del acuerdo que establece normas mínimas en materia de seguridad social. Dicho convenio comienza señalando que cada trabajador, por el hecho de ser humano, tiene derecho a la seguridad social. El convenio establece principios fundamentales en materia de seguridad social y normas mínimas en las siguientes ramas: asistencia médica, prestaciones monetarias de enfermedad, prestaciones de desempleo, de vejez, prestaciones en caso de accidentes de trabajo y enfermedad profesional, prestaciones familiares, de maternidad, de invalidez y prestaciones de sobrevivientes.

Cabe señalar que México ratificó el Convenio 102 en 1961, pero sólo las partes I (asistencia médica), II (prestaciones monetarias de enfermedad), IV (prestaciones de vejez), V (prestaciones en caso de accidente de trabajo y enfermedad profesional), VII (prestaciones de maternidad) y IX (prestaciones de sobrevivientes). 
Este libro forma parte del acervo de la Biblioteca Jurídica Virtual del Instituto de Investigaciones Jurídicas de la UNAM

En lo que respecta a los accidentes y enfermedades de trabajo, el Convenio 102 establece que las contingencias cubiertas, cuando sean ocasionadas por un accidente de trabajo o una enfermedad profesional prescritos, deben comprender las siguientes:

a) Estado mórbido.

b) Incapacidad para trabajar que resulte de un estado mórbido y entrañe la suspensión de ganancias, según defina la legislación nacional.

c) Pérdida total de la capacidad para ganar o pérdida parcial que exceda de un grado prescrito, cuando sea probable que dicha pérdida total o parcial sea permanente, o disminución correspondiente de las facultades físicas.

d) Pérdida de medios de existencia sufrida por la viuda o los hijos como consecuencia de la muerte del sostén de familia; en el caso de la viuda, el derecho a las prestaciones puede quedar condicionado a la presunción, conforme a la legislación nacional, de que es incapaz de subvenir a sus propias necesidades.

Asimismo, las personas protegidas deben comprender:

a) A categorías prescritas de asalariados que en total constituyan, por lo menos, el 50\% de todos los asalariados, y, para las prestaciones a que da derecho la muerte del sostén de familia, también a las cónyuges y a los hijos de los asalariados de esas categorías.

b) Cuando se haya formulado una declaración en virtud del artículo 3o., a categorías prescritas de asalariados que en total constituyan, por lo menos, el 50\% de todos los asalariados que trabajen en empresas industriales en las que estén empleadas, como mínimo, veinte personas, y, para las prestaciones a que da derecho la muerte del sostén de familia, también a los cónyuges y a los hijos de los asalariados de esas categorías. 
Este libro forma parte del acervo de la Biblioteca Jurídica Virtual del Instituto de Investigaciones Jurídicas de la UNAM

Respecto al Convenio 155, ratificado por México en 1984, debemos señalar que prevé la adopción de una política nacional coherente sobre seguridad y salud en el trabajo, y acciones de los gobiernos y dentro de las empresas, para promover la seguridad y la salud en el trabajo y mejorar las condiciones de trabajo. Esta política debe ser desarrollada tomando en consideración las condiciones y las prácticas nacionales. Por otro lado, el protocolo de este convenio (2002) exige el establecimiento y la revisión periódica de los requisitos y procedimientos para el registro y la notificación de los accidentes y las enfermedades en el trabajo, así como la publicación de las estadísticas anuales.

\section{B. Convenio 161}

Por su parte, el convenio sobre los servicios de salud en el trabajo de 1985 (núm. 161), ratificado por México en 1987, prevé el establecimiento de servicios de salud en el ámbito de la empresa, con funciones preventivas y responsables de aconsejar al empleador, a los trabajadores y a sus representantes en la empresa acerca del mantenimiento de un ambiente de trabajo seguro y saludable.

\section{G. Convenio 187}

Este convenio, sobre el marco promocional para la seguridad y salud en el trabajo de 2006 - que no ha sido ratificado por Mé$\mathrm{xico}_{-}^{-}$, tiene por objeto promover una cultura de prevención en materia de seguridad y salud con vistas al logro progresivo de un medio de trabajo seguro y saludable. Establece que los Estados ratificantes deben desarrollar, en consulta con las organizaciones de empleadores y trabajadores más representativas, políticas, sistemas y programas nacionales de seguridad y salud en el trabajo. Los sistemas nacionales deben suministrar la infraestruc- 
Este libro forma parte del acervo de la Biblioteca Jurídica Virtual del Instituto de Investigaciones Jurídicas de la UNAM

tura necesaria para la implementación de políticas y programas nacionales de seguridad y salud en el trabajo, lo cual incluye la legislación, las autoridades o los órganos adecuados y los mecanismos de control, tales como sistemas de inspección y acuerdos a nivel de la empresa. Igualmente, los programas nacionales deben incluir medidas de promoción de la seguridad y la salud en el trabajo con plazos vinculantes que permitan evaluar los progresos logrados.

Asimismo, la OIT cuenta con algunos convenios en materia de salud y seguridad que se refieren, de manera concreta, a algunas ramas de la actividad económica, a saber:

a) Convenio 120, sobre la higiene en comercio y oficinas, de 1964 y ratificado por México en 1968. Este convenio busca preservar la salud y el bienestar de los trabajadores empleados en establecimientos comerciales, instituciones y servicios administrativos, sobre todo para trabajos de oficina y otros servicios relacionados, a través de medidas de higiene elementales, respondiendo a los requisitos de bienestar en el lugar de trabajo.

b) Convenio 152, sobre seguridad e higiene en trabajos portuarios y de 1979, ratificado por México en 1982, se refiere a implementar medidas de salud y seguridad en la totalidad o en cada una de las partes de los trabajos de carga o descarga de todo buque.

c) Convenio 167, sobre seguridad y salud en la construcción, de 1988 y ratificado por México en 1990, establece medidas técnicas detalladas de prevención y protección para el sector en comento, particularmente en lo que se refiere a su seguridad en los lugares de trabajo, con las máquinas y los equipos utilizados, con el trabajo llevado a cabo en las alturas y con el trabajo realizado con aire comprimido.

d) Convenio 176, sobre seguridad y salud en las minas, de 1995 y que no ha sido ratificado por México, relativo a 
Este libro forma parte del acervo de la Biblioteca Jurídica Virtual del Instituto de Investigaciones Jurídicas de la UNAM

la inspección, las herramientas especiales de trabajo y el equipo especial de protección de los trabajadores mineros.

e) Convenio 184, sobre la seguridad y la salud en la agricultura, de 2001 y que no ha sido ratificado por México. El convenio incluye medidas relativas a la seguridad de la maquinaria y a la ergonomía, al manejo y transporte de materiales, a la gestión racional de los productos químicos, al manejo de animales, a la protección contra los riesgos biológicos y a los servicios de bienestar y alojamiento tanto en la agricultura como en el ámbito forestal.

Como se puede observar, en los convenios por ramas de la actividad económica no encontramos instrumentos que se puedan aplicar a los trabajadores de la salud. Situación que sí podemos observar en los convenios que se refieren a riesgos específicos.

\section{Convenios internacionales contra riesgos específicos}

Entre este tipo de convenios podemos encontrar los mencionados a continuación:

\section{A. Convenio 115}

Este convenio, sobre la protección contra las radiaciones, de 1960 y ratificado por México en 1983, establece los requisitos mínimos para proteger contra los riesgos asociados con la exposición a radiaciones ionizantes. Las medidas de protección que han de tomarse deben incluir el límite a la exposición del trabajador a las radiaciones ionizantes al nivel práctico más bajo, evitar toda exposición innecesaria, el control del lugar de trabajo y de la salud de los trabajadores, así como las medidas que se deben tomar en situaciones de emergencia. 
Este libro forma parte del acervo de la Biblioteca Jurídica Virtual del Instituto de Investigaciones Jurídicas de la UNAM

\section{B. Convenio 139}

Este convenio sobre el cáncer profesional, de 1974 y que no ha sido ratificado por México, se refiere a las medidas para prevenir los riesgos del cáncer profesional ocasionado por la exposición a ciertas sustancias. Los Estados deben identificar periódicamente las sustancias y los agentes cancerígenos cuya exposición profesional debe prohibirse o regularse, además de no escatimar esfuerzos de cara a sustituir estas sustancias y agentes por aquellos no cancerígenos o menos cancerígenos, para prescribir medidas de protección y supervisión, así como prescribir los exámenes médicos necesarios para los trabajadores expuestos.

\section{Convenio 148}

El convenio sobre el medio ambiente de trabajo relativo a la contaminación del aire, ruido y vibraciones, de 1977 y que no ha sido ratificado por México, señala que el ambiente de trabajo debe estar libre, en la medida de lo posible, de todo peligro debido a la contaminación del aire, al ruido o a las vibraciones. Por lo que se requiere aplicar a las empresas, o a los procesos, medidas técnicas o adoptar medidas complementarias respecto de la organización del trabajo.

\section{Convenio 162}

El convenio sobre el asbesto, de 1986 y que tampoco ha sido ratificado por México, busca prevenir los efectos perjudiciales para la salud por la exposición al asbesto, indicando métodos razonables y factibles y técnicas para reducir al mínimo dicha exposición. 
Este libro forma parte del acervo de la Biblioteca Jurídica Virtual del Instituto de Investigaciones Jurídicas de la UNAM

\section{E. Convenio 170}

El convenio sobre los productos químicos, de 1990 y ratificado por México en 1992, establece la adopción y la aplicación de una política coherente en materia de seguridad en la utilización de productos químicos en el trabajo, que incluyen la producción, manipulación, almacenamiento y transporte de productos químicos, así como la eliminación y el tratamiento de los desechos de productos químicos, la emisión de productos químicos resultante del trabajo, el mantenimiento, la reparación y la limpieza del equipo y de los recipientes utilizados para los productos químicos.

\section{F. Acuerdo marco para la prevención de las lesiones causadas} por instrumentos cortantes y punzantes en el sector hospitalario y sanitario celebrado por HOSPEM y EPSU

Aunque no se trata de un convenio de la OIT, es importante señalar que el 17 de noviembre de 2008 el European Hospital and Healthcare Employers' Association (HOSPEEM) y la European Federation of Public Services Unions (EPSU) comunicaron a la Comisión Europea de la Unión Europea su deseo de entablar negociaciones, con objeto de celebrar el Acuerdo marco para la prevención de las lesiones causadas por instrumentos cortantes y punzantes en el sector hospitalario y sanitario.

\section{LA PROTECGIÓN DE LOS TRABAJADORES DE LA SALUD A LA LUZ DE LA LEGISLACIÓN NACIONAL}

En materia de legislación nacional, la protección de los trabajadores de la salud tiene un fundamento constitucional y una amplia legislación secundaria: 
Este libro forma parte del acervo de la Biblioteca Jurídica Virtual del Instituto de Investigaciones Jurídicas de la UNAM

- La Constitución.

- Los tratados internacionales en la materia.

- La Ley Federal del Trabajo.

- La Ley Federal sobre Metrología y Normalización.

- La Ley Orgánica de la Administración Pública Federal.

- El Reglamento Federal de Seguridad y Salud en el Trabajo.

- Las normas oficiales mexicanas.

- Los ordenamientos profesionales.

En esta sección nos referiremos a las fuentes de derecho interno relativas a la materia que nos ocupa en el presente ensayo.

\section{La Constitución}

Particularmente el artículo 123, apartado A, fracción XV, de la Constitución Política de los Estados Unidos Mexicanos, establece que el empleador está obligado a observar, de acuerdo con la naturaleza de su negociación, los preceptos legales sobre higiene y seguridad en las instalaciones de su establecimiento y a adoptar las medidas adecuadas para prevenir accidentes en el uso de las máquinas, instrumentos y materiales de trabajo, así como a organizar de tal manera éste, que resulte la mayor garantía para la salud y la vida de los trabajadores.

\section{La Ley Federal del Trabajo}

La LFT, al ser una ley constitucional, establece la regulación general en materia de enfermedades y riesgos de trabajo. Se trata de disposiciones normativas que son aplicables a todos los trabajadores, entre ellos, a los trabajadores de la salud.

Asimismo, la LFT establece las obligaciones del empleador y del trabajador en materia de salud, seguridad y medio ambiente en el trabajo, con el objetivo de prevenir riesgos de trabajo, es decir, enfermedades y accidentes de trabajo. También señala la 
Este libro forma parte del acervo de la Biblioteca Jurídica Virtual del Instituto de Investigaciones Jurídicas de la UNAM

obligación de respetar los reglamentos o instructivos elaborados por la STPS o las normas oficiales mexicanas (NOM's) y aquellas señaladas por los patrones destinadas a proteger la salud y seguridad del trabajador.

La LFT regula, en su título noveno, los riesgos de trabajo, así como las indemnizaciones que correspondan dependiendo del tipo de riesgo de trabajo del que se trate. Dicha ley define los riesgos de trabajo como los accidentes y enfermedades a que están expuestos los trabajadores en ejercicio o con motivo del trabajo. Un riesgo de trabajo puede producir:

- Incapacidad temporal: pérdida de facultades o aptitudes que imposibilita parcial o totalmente a una persona para desempeñar su trabajo por algún tiempo.

- Incapacidad permanente parcial: disminución de las facultades o aptitudes de una persona para trabajar.

- Incapacidad permanente total: pérdida de facultades o aptitudes de una persona que la imposibilita para desempeñar cualquier trabajo por el resto de su vida.

- Muerte.

La existencia de estados anteriores, tales como idiosincrasias, taras, discrasias, intoxicaciones o enfermedades crónicas, no es causa para disminuir el grado de la incapacidad ni las prestaciones que correspondan al trabajador.

El trabajador que sufra un riesgo de trabajo tiene derecho al pago de una indemnización, la cual se le pagará de manera directa. En caso de incapacidad mental, comprobada ante una Junta de Conciliación y Arbitraje, la indemnización se le paga a la persona o las personas beneficiarias del trabajador. La cantidad que se tome como base para el pago de las indemnizaciones no podrá ser inferior al salario mínimo. Para determinar las indemnizaciones, si el salario que percibe el trabajador excede del doble del salario mínimo del área geográfica de aplicación a que corresponda el lugar de prestación del trabajo, se considerará esa cantidad como 
Este libro forma parte del acervo de la Biblioteca Jurídica Virtual del Instituto de Investigaciones Jurídicas de la UNAM

salario máximo. Si el trabajo se presta en lugares de diferentes áreas geográficas de aplicación, el salario máximo será el doble del promedio de los salarios mínimos respectivos. Específicamente, los trabajadores que sufran un riesgo de trabajo tendrán derecho a:

- Asistencia médica y quirúrgica.

- Rehabilitación.

- Hospitalización, cuando el caso lo requiera.

- Medicamentos y material de curación.

- Aparatos de prótesis y ortopedia necesarios.

- Indemnización.

En materia de riesgos de trabajo, los inspectores del trabajo tienen las atribuciones y deberes especiales siguientes:

- Vigilar el cumplimiento de las normas legales y reglamentarias sobre prevención de los riesgos de trabajo y seguridad de la vida y salud de los trabajadores.

- Hacer constar en actas especiales las violaciones que descubran.

- Colaborar con los trabajadores y el patrón en la difusión de las normas sobre prevención de riesgos, higiene y salubridad.

Finalmente, cabe señalar que con el objeto de estudiar y proponer la adopción de medidas preventivas para abatir los riesgos en los centros de trabajo, se ha creado la Comisión Consultiva Nacional de Seguridad e Higiene en el Trabajo, integrada por representantes de la STPS y la SSa, el Instituto Mexicano del Seguro Social (IMSS), así como por los que designen aquellas organizaciones nacionales de trabajadores y de patrones a las que convoque el titular de la STPS, quien tiene el carácter de presidente de la citada comisión.

Asimismo, en cada entidad federativa se debe constituir una Comisión Consultiva Estatal de Seguridad e Higiene en el Trabajo, cuya finalidad sea la de estudiar y proponer la adopción de 
Este libro forma parte del acervo de la Biblioteca Jurídica Virtual del Instituto de Investigaciones Jurídicas de la UNAM

todas aquellas medidas preventivas para abatir los riesgos en los centros de trabajo comprendidos en su jurisdicción.

Dichas comisiones consultivas estatales son presididas por los gobernadores de las entidades federativas, y en su integración participarán también representantes de la STPS, la SSa y del IMSS, así como los que designen las organizaciones de trabajadores y de patrones a las que convoquen, conjuntamente, la STPS y el gobernador de la entidad correspondiente. El funcionamiento interno de dichas comisiones se fijará en el reglamento interior que cada comisión expida.

\section{La Ley Orgánica de la Administración Pública Federal}

Esta ley faculta a la STPS, en su artículo 40, fracción XI, para estudiar y ordenar las medidas de seguridad e higiene para la protección de los trabajadores.

\section{La Ley Federal sobre Metrología y Normalización}

Ley que, en sus artículos 38, fracción II; 40, fracción VII, y 43 al 47, establece la competencia de las dependencias para expedir las NOM's relacionadas con sus atribuciones.

\section{El Reglamento Federal de Seguridady Salud en el Trabajo}

Establece, en su artículo 10, la facultad de la STPS para expedir normas con fundamento en la Ley Federal sobre Metrología y Normalización y su reglamento, la LFT y el presente reglamento, con el propósito de establecer disposiciones en materia de seguridad y salud en el trabajo que eviten riesgos que pongan en peligro la vida, la integridad física o la salud de los trabajadores, y cambios adversos y sustanciales en el ambiente laboral que afecten o puedan afectar la seguridad o salud de los trabajadores 
Este libro forma parte del acervo de la Biblioteca Jurídica Virtual del Instituto de Investigaciones Jurídicas de la UNAM

o provocar daños a las instalaciones, maquinaria, equipos y materiales del centro de trabajo.

\section{Las normas oficiales mexicanas}

Las NOM's elaboradas por la STPS determinan las condiciones mínimas necesarias para la prevención de riesgos de trabajo y se caracterizan porque se destinan a la atención de factores de riesgo a los que pueden estar expuestos los trabajadores.

Actualmente se encuentran vigentes 41 NOM's en materia de seguridad y salud en el trabajo. Dichas normas se agrupan en cinco categorías:

- Seguridad.

- Salud.

- Organización.

- Específicas.

- De producto.

En los siguientes cuadros se enuncian las NOM's correspondientes a cada una de estas categorías:

NORMAS DE SEGURIDAD

\begin{tabular}{|c|c|}
\hline Número & Título de la norma \\
\hline NOM-001-STPS-2008 & Edificios, locales e instalaciones \\
\hline NOM-002-STPS-2010 & Prevención y protección contra incendios \\
\hline NOM-004-STPS-1999 & $\begin{array}{c}\text { Sistemas y dispositivos de seguridad en } \\
\text { maquinaria }\end{array}$ \\
\hline NOM-005-STPS-1998 & $\begin{array}{c}\text { Manejo, transporte y almacenamiento de } \\
\text { sustancias peligrosas }\end{array}$ \\
\hline NOM-006-STPS-2014 & Manejo y almacenamiento de materiales \\
\hline NOM-009-STPS-2011 & Trabajos en altura \\
\hline NOM-020-STPS-2011 & Recipientes sujetos a presión y calderas \\
\hline NOM-022-STPS-2008 & Electricidad estática \\
\hline
\end{tabular}


Este libro forma parte del acervo de la Biblioteca Jurídica Virtual del Instituto de Investigaciones Jurídicas de la UNAM

\begin{tabular}{|c|c|}
\hline Número & Título de la norma \\
\hline NOM-027-STPS-2008 & Soldadura y corte \\
\hline NOM-029-STPS-2011 & Mantenimiento de instalaciones eléctricas \\
\hline
\end{tabular}

\section{NORMAS DE SALUD}

\begin{tabular}{|c|c|}
\hline Número & Titulo de la norma \\
\hline NOM-010-STPS-1999 & Contaminantes por sustancias químicas \\
\hline NOM-011-STPS-2001 & Ruido \\
\hline NOM-012-STPS-2012 & Radiaciones ionizantes \\
\hline NOM-013-STPS-1993 & Radiaciones no ionizantes \\
\hline NOM-014-STPS-2000 & Presiones ambientales anormales \\
\hline NOM-015-STPS-2001 & Condiciones térmicas elevadas o abatidas \\
\hline NOM-024-STPS-2001 & Vibraciones \\
\hline NOM-025-STPS-2008 & Iluminación \\
\hline
\end{tabular}

\section{NORMAS DE ORGANIZAGIÓN}

\begin{tabular}{|c|c|}
\hline Número & Titulo de la norma \\
\hline NOM-017-STPS-2008 & Equipo de protección personal \\
\hline NOM-018-STPS-2000 & $\begin{array}{c}\text { Identificación de peligros y riesgos } \\
\text { por sustancias químicas }\end{array}$ \\
\hline NOM-019-STPS-2011 & Comisiones de seguridad e higiene \\
\hline NOM-026-STPS-2008 & Colores y señales de seguridad \\
\hline NOM-028-STPS-2012 & $\begin{array}{c}\text { Seguridad en procesos y equipos } \\
\text { con sustancias químicas }\end{array}$ \\
\hline NOM-030-STPS-2009 & Servicios preventivos de seguridad y salud \\
\hline
\end{tabular}

\section{NORMAS ESPECÍFICAS}

\begin{tabular}{|c|c|}
\hline Número & Titulo de la norma \\
\hline NOM-003-STPS-1999 & Plaguicidas y fertilizantes \\
\hline NOM-007-STPS-2000 & $\begin{array}{c}\text { Instalaciones, maquinaria, equipo } \\
\text { y herramientas agrícolas }\end{array}$ \\
\hline NOM-008-STPS-2001 & $\begin{array}{c}\text { Aprovechamiento forestal maderable } \\
\text { y aserraderos }\end{array}$ \\
\hline NOM-016-STPS-2001 & Operación y mantenimiento de ferrocarriles \\
\hline
\end{tabular}


Este libro forma parte del acervo de la Biblioteca Jurídica Virtual del Instituto de Investigaciones Jurídicas de la UNAM

\begin{tabular}{|c|c|}
\hline Número & Título de la norma \\
\hline NOM-023-STPS-2012 & $\begin{array}{c}\text { Trabajos en minas subterráneas } \\
\text { y a cielo abierto }\end{array}$ \\
\hline NOM-031-STPS-2011 & Construcción \\
\hline NOM-032-STPS-2008 & Minas subterráneas de carbón \\
\hline
\end{tabular}

Normas de producto. Se cuenta con seis normas de producto relativas a equipos contra incendio y tres sobre equipo personal.

De las anteriores cinco categorías, las tres primeras - es decir, seguridad, salud y organización - se aplican de manera obligatoria en los centros de trabajo que desarrollan actividades de producción, comercialización, transporte y almacenamiento o prestación de servicios, en función de las características de las actividades que desarrollan y de las materias primas, productos y subproductos que se manejan, transportan, procesan o almacenan. Es en el caso de la prestación de servicios donde podemos encuadrar a los trabajadores del sector salud.

Para la cuarta categoría se prevé su aplicación obligatoria en las empresas que pertenecen a los sectores o actividades específicos a que se refieren tales normas. En este caso no encontramos una NOM destinada a los trabajadores del sector salud.

La quinta categoría corresponde a las empresas que fabrican, comercializan o distribuyen equipos contra incendio y de protección personal, que sólo podrían pensarse destinadas a los centros donde laboran los trabajadores de la salud.

\section{Carta de los Derechos Generales de las y los Médicos}

En el año 2001 se solicitó la participación de la Comisión Nacional de Arbitraje Médico (Conamed) para coordinar la elaboración de la Carta de los Derechos Generales de las y los Médicos. Además de la Conamed, participaron representantes de la Subsecretaría de Innovación y Calidad de la 
Este libro forma parte del acervo de la Biblioteca Jurídica Virtual del Instituto de Investigaciones Jurídicas de la UNAM

SSa, la Comisión Nacional de Bioética, la Comisión Nacional de Derechos Humanos, la Dirección de Prestaciones Médicas del IMSS, la Subdirección General Médica y Subdirección de Regulación de Servicios de Salud del Instituto de Seguridad y Servicios Sociales de los Trabajadores del Estado (ISSSTE), la Academia Mexicana de Cirugía, la Academia Nacional de Medicina, el Comité Normativo Nacional de Consejos de Especialidades Médicas, la Federación Nacional de Colegios de la Profesión Médica (Colegio Médico de México), el Colegio de Médicos Lasallistas y la Dirección General de Asuntos Jurídicos de la SSa.

La Carta de los Derechos Generales de las y los Médicos es una regulación de naturaleza profesional que resulta importante comentar en la medida que también aborda el tema de los riesgos de trabajo del personal de la salud. Entre los puntos que se pueden destacar sobresalen los siguientes:

- Laborar en instalaciones apropiadas y seguras que garanticen su práctica profesional.

- El derecho del médico a contar con lugares de trabajo e instalaciones que cumplan con medidas de seguridad e higiene, incluidas las que marca la ley, de conformidad con las características del servicio a otorgar.

\section{LA REALIDAD DE LOS TRABAJADORES DE LA SALUD: \\ ENTRE UNA PROTECGIÓN FORMAL \\ Y UNA DESPROTEGGIÓN GONGRETA}

Como se puede apreciar, la protección de los trabajadores de la salud tiene un anclaje internacional y nacional. En materia nacional, la LFT hace referencia a los derechos de los trabajadores en materia de higiene y salud en el trabajo. En esa ley se pueden encontrar todas las obligaciones del empleador en función del tamaño de la empresa; por ejemplo, la obligación de tener un botiquín, medi- 
Este libro forma parte del acervo de la Biblioteca Jurídica Virtual del Instituto de Investigaciones Jurídicas de la UNAM

camentos y una enfermería, en el caso de aquellos centros donde haya más de cien trabajadores, e instalar un hospital si hay más de trescientos trabajadores. Igualmente, en la LFT encontramos una serie de señalamientos con relación a cómo debe funcionar la medicina en el trabajo, la obligación de que existan comisiones de seguridad e higiene en el espacio laboral, así como una comisión consultiva nacional de seguridad e higiene y una comisión estatal consultiva.

Si lo vemos desde el punto de vista estrictamente formal, el país cuenta con una regulación amplia en materia de salud. Así, en la tabla de enfermedades en el trabajo que se encuentra en la LFT encontramos una serie de enfermedades donde se podría identificar claramente al personal de la salud.

Igualmente, existe también una serie de normas oficiales que busca la protección de la seguridad y de la higiene en el trabajo. En el caso de las NOM's podemos hacer la división entre normas de salud y de higiene en el trabajo general y otras de naturaleza específica que van a cubrir un determinado tipo de actividad, como la construcción, la minería, los trabajos e instalaciones de operación y mantenimiento de ferrocarriles, entre otras.

No obstante, a pesar de la amplia regulación existente en la materia, la práctica de la misma tiene una distancia enorme en relación con lo que está establecido en la norma. En el caso de nuestro país, se debe hacer una diferencia sustancial entre hospitales públicos y privados, ya que no cuentan con la misma infraestructura e insumos.

En el caso de centros de salud, clínicas y hospitales públicos, la carencia de recursos es evidente. El fenómeno aparece más claro cuando hablamos de instituciones de salud federales y estatales o de institutos de seguridad social. Hay que reflexionar con más profundidad sobre el sector salud en México. Mi propuesta para aterrizar el tema: resulta paradójico que en los últimos años ha habido un incremento del presupuesto en materia de salud por parte del Estado; pero en estos mismos años se ha incrementado el gasto de bolsillo en servicios de salud. La preo- 
Este libro forma parte del acervo de la Biblioteca Jurídica Virtual del Instituto de Investigaciones Jurídicas de la UNAM

cupación del Estado se ha centrado en incrementar la cobertura del servicio, pero no la calidad del mismo, repercutiendo en las condiciones de trabajo de los trabajadores de la salud, y en ese sentido, en el incremento de sufrir algún accidente de trabajo debido a riesgos biológicos.

Terminaría con dos conclusiones: la primera consiste en analizar la regulación en el contexto de cómo funciona la práctica médica en nuestro país; es decir, un contexto formado por un Sistema Nacional de Salud, un Seguro Popular, el ISSSTE y el IMSS, así como los servicios médicos del sector privado. Como segunda conclusión señalaría que tendríamos que pensar en la necesidad de empezar a diseñar una regulación especial o específica para los riesgos de salud de los profesionales de dicha materia a través de un agregado en la LFT. Se debe recordar al respecto que la LFT tiene un capítulo relativo a los trabajadores especiales. Quizá llegó la hora, dada la importancia y la particularidad del trabajo médico, de contar con la regulación especial dedicada a los trabajadores de la salud.

\section{ANEXO}

Constitución Política de los Estados Unidos Mexicanos, artículo 4o., Diario Oficial de la Federación (DOF) 05/02/1917, última reforma DOF 15/02/2012.

Ley General de Salud, artículo 3o., XV; 59, 64, III; 133, 134, I; 136, 138, 139 y 141., DOF 7/02/1984, última reforma $D O F$ $07 / 06 / 2012$.

Ley General para la Prevención y Gestión Integral de los Residuos, DOF 04/06/2014.

Norma Oficial Mexicana NOM-017-SSA2-2012, Para la vigilancia epidemiológica, DOF 19/02/2013.

Norma Oficial Mexicana NOM-087-SEMARNAT-SSA1-2002, Protección ambiental-Salud ambiental-Residuos peligrosos biológico/infecciosos-Clasificación y especificaciones de manejo. 
Este libro forma parte del acervo de la Biblioteca Jurídica Virtual del Instituto de Investigaciones Jurídicas de la UNAM

Norma Oficial Mexicana NOM-052-SEMARNAT-2005, Que establece las características, el procedimiento de identificación, clasificación y los listados de los residuos peligrosos, $D O F$ 23/06/2006.

Norma Oficial Mexicana NOM-007-SSA3-2011, Para la organización y funcionamiento de los laboratorios clínicos, $D O F$ $27 / 03 / 2012$.

PROY-NOM-005-STPS-2004, Manejo de sustancias químicas peligrosas, condiciones y procedimientos de seguridad y salud en los centros de trabajo.

NOM-010-SCT2-2003, Disposiciones de compatibilidad y segregación para el almacenamiento y transporte de sustancias, materiales y residuos peligrosos.

DOF $10 / 12 / 2003$.

Norma Oficial Mexicana NOM-032-SSA2-2010, Para la vigilancia epidemiología, prevención y control de enfermedades transmitidas por vector.

Secretaría de Salud, Programa Sectorial de Salud 2013-2018, DOF $12 / 12 / 2013$.

Plan Nacional de Desarrollo 2013-2018, DOF 20/05/2013, wrere. dof.gob.mx.

Secretaría de Salud, Programa de Acción Específico 2013-2018, Sistema Nacional de Vigilancia Epidemiológica, primera edición, 2014.

Lineamientos para programas de evaluación externa del desempeño de la Red Nacional de Laboratorios de Salud Pública, InDRE-Secretaría de Salud, 2014.

Criterios de Operación para la Red Nacional de Laboratorios de Salud Pública, DGE-InDRE-RNLSP, Secretaría de Salud, 2014.

Lineamientos para la vigilancia epidemiológica de la enfermedad de Chagas por laboratorio, InDRE-RNLSP, 2014. 
Este libro forma parte del acervo de la Biblioteca Jurídica Virtual del Instituto de Investigaciones Jurídicas de la UNAM

Lineamientos para la vigilancia epidemiológica de influenza por laboratorio, DGE-InDRE-RNLSP, 2014.

Lineamientos para la vigilancia epidemiológica de rotavirus por laboratorio, DGE-InDRE-RNLSP, 2014.

Lineamientos para la vigilancia epidemiológica de dengue por laboratorio, DGE-InDRE-RNLSP, 2014.

Lineamientos para la vigilancia epidemiológica de paludismo por laboratorio, DGE-InDRE-RNLSP, 2014.

Lineamientos para la vigilancia epidemiológica de Leishmaniasis por laboratorio, DGE-InDRE-RNLSP, 2014.

Lineamientos para la vigilancia epidemiológica de la enfermedad diarreica aguda bacteriana por laboratorio, DGE-InDRERNLSP, 2014.

Lineamientos para la vigilancia epidemiológica de la enfermedad febril exantemática por laboratorio, DGE-InDRE-RNLSP, 2014.

Lineamientos para la vigilancia epidemiológica de la carga viral por laboratorio, DGE-InDRE-RNLSP, 2014.

Lineamientos para la vigilancia epidemiológica de infecciones de transmisión sexual por laboratorio, DGE-InDRE-RNLSP, 2014.

Lineamientos para la vigilancia epidemiológica de rabia por laboratorio, DGE-InDRE-RNLSP, 2014.

Lineamientos para la vigilancia epidemiológica de tosferina por laboratorio, DGE-InDRE-RNLSP, 2014.

Lineamientos para la vigilancia epidemiológica de la infección del VIH por laboratorio, DGE-InDRE-RNLSP, 2014.

Lineamientos para la vigilancia entomológica por laboratorio, DGE-InDRERNLSP, 2014.

Lineamientos para la vigilancia epidemiológica de difteria por laboratorio, DGE-InDRE-RNLSP.

Lineamientos para la vigilancia epidemiológica de hepatitis viral por laboratorio, DGE-InDRE-RNLSP, 2014. 
Este libro forma parte del acervo de la Biblioteca Jurídica Virtual del Instituto de Investigaciones Jurídicas de la UNAM

Lineamientos para la vigilancia epidemiológica de cáncer cérvicouterino por laboratorio, DGE-InDRE-RNLSP, 2014.

Lineamientos para los programas de Evaluación Externa del Desempeño de la Red Nacional de Laboratorios de Salud Pública, DGE-InDRE-RNLSP, 2014.

Manual para la toma, envío y recepción de muestras para diagnóstico, DGE-InDRE-RNLSP, 2014.

Manual de la evaluación del desempeño "Caminando a la excelencia”, México, DGE-InDRE-RNLSP, 2014.

Lineamientos del Sistema de Reconocimiento a la Competencia Técnica de Laboratorios que Apoyan a la Vigilancia Epidemiológica, DGE-InDRE-RNLSP, 2014.

Lineamientos para la gestión del riesgo biológico, Dirección General de Epidemiología. 
Este libro forma parte del acervo de la Biblioteca Jurídica Virtual del Instituto de Investigaciones Jurídicas de la UNAM

\title{
ASPECTOS GLÍNICOS Y NORMATIVOS DE LA REGULACIÓN DE LA PROTEGGIÓN DE LOS TRABAJADORES DE LA SALUD
}

\section{Edgar Enrique Sevilla Reyes*}

\begin{abstract}
SUMARIO: I. Introducción. II. Tipos de paciente y tipos de enfermedad: riesgos diferentes. III. "Una sola salud" y marco regulatorio. IV. Conclusión.
\end{abstract}

\section{INTRODUCCIÓN}

Presento estas líneas a nombre de la Asociación Mexicana de Bioseguridad (Amexbio), de la cual fui presidente fundador en el 2009 para trabajar en el tema de hospitales, institutos, universidades, centros de investigación, centros de producción e industria farmacéutica, entre otros sitios donde se manejan materiales biológicamente activos.

En Amexbio entendemos la bioseguridad como todo aquello que se hace, o que se tiene que hacer, para prevenir la exposición accidental o la liberación no intencionada de material biológico. Es parte fundamental de todo lo que hacemos, que toda actividad sea segura para el trabajador, su comunidad y todo el ambiente que nos rodea.

* Ph. D., presidente fundador (2009-2010) de la Asociación Mexicana de Bioseguridad A. C. e investigador en ciencias médicas "C" del Instituto Nacional de Enfermedades Respiratorias. Este texto es producto de la versión estenográfica editada por personal del Instituto de Investigaciones Jurídicas de la UNAM. 
Este libro forma parte del acervo de la Biblioteca Jurídica Virtual del Instituto de Investigaciones Jurídicas de la UNAM

Estas ideas contrastan muchísimo con la manera de trabajar en algunas áreas, donde tradicionalmente están acostumbrados a realizar las cosas de cierta manera; por ejemplo, poniendo toda su preocupación en la calidad del producto o en que se mantenga estéril un área, u optimizando los recursos para la atención a la salud de los pacientes. Sin embargo, en nuestra experiencia hemos observado que en algunos de estos procesos, la salud y la seguridad de los trabajadores es lo último que se mira. Nos topamos con clínicas y laboratorios donde el personal de salud debe reusar sus guantes, e incluso decidir cuidadosamente cuándo usarlos, pues sólo recibe un número preestablecido cada mes, sin que exista una estimación formal del riesgo de exposición a material biológico infeccioso que tiene ese trabajador.

Lo que hacemos en la Amexbio es promover la cultura de la bioseguridad, que consiste en prevenir y evitar responsablemente que los peligros biológicos lleguen accidentalmente a las personas; pero también promovemos la biocustodia, que trata de evitar que las personas, intencionalmente, entren en contacto y utilicen los materiales biológicos con fines ilegítimos o sin tener la autorización adecuada.

\section{TIPOS DE PACIENTE Y TIPOS DE ENFERMEDAD: RIESGOS DIFERENTES}

En cualquier área clínica, en cualquier sala de espera, tenemos muchos pacientes; en cualquier laboratorio recibimos muchísimas muestras biológicas, pero nunca tenemos forma de saber cuál paciente es más peligroso que el resto o cuál padece una nueva enfermedad. En esta generación altamente conectada ya hemos visto la influenza H1N1, a los virus de Ébola, del Zika y el chikungunya, a las bacterias multirresistentes a antibióticos, entre otras, y aún estamos lejos de contar con herramientas para el diagnóstico inmediato. ¿Cuántas personas circulan por hospitales, clínicas o laboratorios todos los días? Contemos los produc- 
Este libro forma parte del acervo de la Biblioteca Jurídica Virtual del Instituto de Investigaciones Jurídicas de la UNAM

tos que pasan por aduanas, personas por fronteras, mosquitos en barcos, etcétera. Entonces necesitamos generar los sistemas, el marco para que podamos lidiar responsablemente con los peligros biológicos que tenemos alrededor.

En varios de nuestros países latinoamericanos la evaluación de riesgo es algo que pareciera que no ocurre, e insistimos de forma necia en que alguien nos entregue normas y guías que nos digan qué hacer en todo momento. Queremos las especificaciones de mi guante, las especificaciones del desinfectante que debo usar, de cuándo y cómo lavar mis manos, de qué punzocortante usar; queremos las especificaciones de todo, que nos resuelvan el problema y no pensar científicamente. No sancionamos, como en el Reino Unido, a quienes deberían ser responsables de la seguridad para elaborar una evaluación de riesgo que sea incompleta o fraudulenta. Comúnmente no la hacemos, preferimos seguir y cumplir con regulaciones prefabricadas, listas para usarse; nos sentimos cómodos con culpar a la autoridad de lo que nos pasa.

He mencionado al ébola. Más de quinientos trabajadores de la salud fallecieron por contagio de este virus durante el 2015, lo cual hubiera sido impensable hace unos años. No sabemos todo sobre las infecciones, pero vamos aprendiendo cada vez más sobre los peligros a los que estamos expuestos. Hace cuarenta años no sabíamos nada del virus de inmunodeficiencia humana (VIH) y casi nadie estaba preocupado por la exposición a sangre. Hoy en día la exposición a sangre y fluidos corporales es una gran preocupación. Y en este punto debemos recordar al médico norteamericano Ian Crozier, quien se curó de ébola, pero luego empezó a tener problemas de visión, e incluso le cambió el color de los ojos. Ocho meses después de la infección encontraron virus en el humor acuoso de sus ojos. Hay casos de infección por virus del Zika donde en sangre de una madre ya no se encuentra el virus, pero meses después de que la madre tuvo la infección hallamos el virus en los tejidos fetales. ¿Quieren una norma para eso? 
Este libro forma parte del acervo de la Biblioteca Jurídica Virtual del Instituto de Investigaciones Jurídicas de la UNAM

Tenemos que lidiar con los peligros biológicos de manera sistemática, y estar preparados ante las infecciones emergentes y reemergentes. Sin embargo, el reto no termina ahí, la tecnología avanza, y avanza demasiado rápido. Existe el sistema CRISPRCas9, que permite modificar el material genético a bajo costo y de forma muy eficiente. Si recordamos nuestras clases de Mendel, ¿cómo es que de los frijolitos, unos eran verdes y otros amarillos? Eso ya no ocurre porque podemos hacer que todas las progenies, todas, sean perfectamente mutantes y que nunca se rescate el original. Se están haciendo tratamientos para diversas enfermedades, incluso esta tecnología ya se utiliza para tratar de curar el VIH, aunque en los primeros intentos el virus se volvió resistente, como siempre. En ciertos países este sistema lo están aplicando a embriones humanos, por lo cual tenemos que aprender a lidiar con todos estos nuevos peligros biológicos de forma sistemática.

Espero que sea claro que la bioseguridad y la biocustodia están más allá del hospital y del laboratorio. Son temas que están cada vez más presentes en la vida diaria de muchas disciplinas.

\section{III. "UNA SOLA SALUD” Y MARCO REGULATORIO}

Aludiré ahora al término "una sola salud". Tal vez no ha sido lo suficientemente comunicado, pero el término hace referencia a que la salud animal, la salud humana y un ambiente sano sólo se logran a través de la colaboración interdisciplinaria, pues gran parte de las infecciones que tenemos los humanos vienen del ámbito animal. A esto último se le denomina zoonosis, como es el caso de la infección por el virus del Zika y el chikungunya. Entonces debemos tener eso presente y también trabajar de la mano con la gente de salud veterinaria; porque ¿son trabajadores de la salud? Sí, lo son.

Es muy interesante que en la época de oro de la bacteriología, a finales del siglo XIX, luego de identificada una nueva bacteria, a los pocos años se tenía un reporte de personas infec- 
Este libro forma parte del acervo de la Biblioteca Jurídica Virtual del Instituto de Investigaciones Jurídicas de la UNAM

tadas por esa bacteria en laboratorio. La causa principal era por los llamados "pipeteos" con la boca - esta acción que si voy a dar capacitaciones a algún lado, todos me juran y me perjuran que ya no ocurre, pues se trata de tomar líquido mediante una pipeta, similar a un popote, pero graduada-, dado que en aquel entonces no contaban con dispositivos adecuados para succionar el líquido, lo hacían con la boca, y eso los exponía a aerosoles, salpicaduras e incluso tragos de cultivos bacterianos.

Hoy en día contamos con múltiples dispositivos manuales y automáticos para la protección de nuestro personal, pero la realidad es que siguen ocurriendo prácticas de antaño que ponen en riesgo a los trabajadores y a su comunidad, tanto en laboratorios clínicos como en laboratorios de investigación. Recientemente fui testigo de un evento así en una de las instituciones científicas de mayor nivel de este país: gente pipeteando con la boca, o inoculando ratones con virus en condiciones inadecuadas, sin la más mínima protección. Gente en hospitales reencapuchando agujas sin ninguna preocupación. Estas cosas siguen ocurriendo, desafortunadamente. Nuestro mundo ha cambiado, pero parece que seguimos atados a costumbres y prácticas del pasado.

Pondré un ejemplo de un documento que no es una ley pero que en Estados Unidos funciona como si lo fuera: el Manual de bioseguridad para laboratorios microbiológicos y biomédicos (BMBL, por sus siglas en inglés) de los Centros de Control y Prevención de Enfermedades (CDC) y los institutos de salud de los Estados Unidos. Si comparamos su primera edición, de 1984, y la quinta, del 2009, es evidente que el manual ha crecido significativamente, lo cual implica que los requerimientos también lo han hecho. Sin embargo, los problemas no cesan. Cabe recordar en este punto lo que ocurrió el año pasado: el CDC estuvo mucho en las noticias por grandes accidentes y problemas que tuvieron con muestras contaminadas con influenza aviar $\mathrm{H} 5 \mathrm{~N} 1$, que se enviaron por error a laboratorios de baja contención por todo el país; o bien, el caso de ciertas instalaciones militares que durante años enviaban esporas de ántrax a diferentes países para pruebas de control de detección 
Este libro forma parte del acervo de la Biblioteca Jurídica Virtual del Instituto de Investigaciones Jurídicas de la UNAM

que nunca fueron inactivadas, o que el proceso de inactivación era muy defectuoso. Claro que había recursos técnicos y económicos para hacerlo, pero al parecer nadie se preocupó por verificar si el procedimiento se había realizado adecuadamente.

Frecuentemente la gente se queja de que las cosas no se hacen bien dado que no hay recursos económicos suficientes. En el 2009 fuimos testigos de que mucha gente recibía equipo de protección respiratoria N95, pero no sabía utilizarlo. Usar el equipo de protección requiere de todo un proceso de capacitación, entrenamiento y demostración de competencia, no una presentación de PowerPoint de quince minutos.

Hay que tener presente que la existencia de una regulación no implica que exista una política pública ni un compromiso por mejorar. Los recursos económicos, o la regulación, son únicamente componentes que por sí solos son insuficientes para resolver problemas complejos. Estados Unidos ha sido un buen ejemplo, y vale mucho la pena estudiar los errores del CDC y en nuestro país ser más abiertos respecto de nuestras equivocaciones, porque ¿en cuántas de nuestras instituciones se quiere meter todo bajo la alfombra? Y aquí no pasó nada, y es preferible despedir a la persona por incompetencia, o alguna otra situación distinta, que reconocer que hubo una falla institucional en la atención de un problema.

En Amexbio hemos identificado al menos 35 normas oficiales y leyes, y más de diez reglamentos que son directamente relevantes para la seguridad del trabajo en el laboratorio; además, hay otras tantas normas para seguridad en áreas clínicas. Entonces, cuando nos dicen que no hay regulación en bioseguridad, eso no exacto; puede que esté desperdigada en múltiples documentos y tener problemas, pero existe toda una serie de ordenamientos en materia de vigilancia, prevención y control de riesgos biológicos para los trabajadores, para la comunidad y para el medio ambiente.

Me voy a detener en un documento que para quienes hacemos investigación es muy importante. Me refiero al Reglamento 
Este libro forma parte del acervo de la Biblioteca Jurídica Virtual del Instituto de Investigaciones Jurídicas de la UNAM

de la Ley General de Salud en Materia de Investigación para la Salud, expedido en 1984, que considero fue adelantado a su tiempo, aunque hoy en día ya muestra sus años. Desde aquel entonces ya solicitaba que todas las instituciones que realizan investigación en salud cuenten con un comité de ética, de investigación y un comité de bioseguridad que revise, que supervise, que asesore sobre el riesgo biológico y, sobre todo, define responsabilidades bien claras a los investigadores que participan en la investigación. Asimismo, en dicho reglamento se exige que todos los laboratorios tengan un manual de bioseguridad con sus procedimientos respectivos. ¿Qué procedimientos vamos a seguir en caso de que alguien se pique o que alguien se lesione?

A pesar de lo anterior, hoy, 32 años más tarde, hay instituciones de investigación en salud que no tienen comités de bioseguridad ni manuales ni procedimientos escritos. Se puede llegar a laboratorios y constatar que no tienen manuales, o bien, comprobar que los comités, cuando existen, en ocasiones son meramente nominativos, rara vez sesionan o el personal asignado lo hace sin tener experiencia o interés.

Entonces, insisto en que la regulación, los recursos y la infraestructura son componentes, pero siempre nos vamos a encontrar la resistencia al cambio. Podríamos proponer en este texto que la seguridad tiene una estructura similar a una cebolla, con múltiples capas que pueden evitar que algo pueda ocurrir. ¿Acaso podemos considerar que la seguridad de un trabajador de la salud está dada únicamente por un guante o por una sola norma? Creo que si así pensáramos nos quedaríamos muy cortos. Tienen que darse muchas cosas y condiciones: lo que llaman jerarquía de controles, la ingeniería que se utiliza, el equipamiento que se emplea, los procedimientos que se siguen, la capacitación que se tiene, las normas que se aplican, la supervisión y las auditorías que se tienen; todo eso tiene que estar integrado en una institución, para que entonces se cuente con un ambiente seguro. 
Este libro forma parte del acervo de la Biblioteca Jurídica Virtual del Instituto de Investigaciones Jurídicas de la UNAM

El gran tema es tener un sistema de gestión de riesgo biológico. En este sentido, en el año 2008 el Comité Europeo de Normalización emitió el documento CWA15793, para la gestión de riesgo biológico en laboratorio. Es un documento importantísimo para gestionar el riesgo en los laboratorios y que ahora, con todos los accidentes que tuvo el CDC, están dándose cuenta de que lo que necesitan es tener ese tipo de sistema. Incluso el documento CWA15793 está intentando llegar a convertirse en una norma ISO, si bien parece ser que se va a quedar como un documento técnico, porque hay varios países, entre ellos Alemania, que por su relevancia rechazan que sea de adopción voluntaria. Estamos ajustando el CWA15793 al entorno y regulación nacional en un documento que llamamos "Lineamientos para la gestión de riesgo biológico", de la Amexbio.

\section{GONCLUSIÓN}

Como breve conclusión: las regulaciones por sí solas no son la solución. Comprar equipos caros o construir elefantes blancos tampoco remedia mucho. En Amexbio creemos que la bioseguridad se construye en capas mediante la interacción de múltiples componentes que conforman un sistema de gestión.

Las organizaciones confiables tienen sistemas de gestión de riesgo que son homólogos al sistema de gestión de calidad. Un sistema de gestión de riesgo biológico es muy similar, y prepara a nuestra institución o empresa para enfrentar los retos de un mundo cambiante y cada vez más acelerado, esto a través de la evaluación de riesgo constante y la mejora continua de todo lo que hacemos, porque a final de cuentas, busca protegernos, proteger a los que nos rodean y a nuestro medio ambiente. 
Este libro forma parte del acervo de la Biblioteca Jurídica Virtual del Instituto de Investigaciones Jurídicas de la UNAM

\title{
LA IMPORTANCIA DE LA PROTECGIÓN DEL DERECHO A LA SALUD DE LOS TRABAJADORES DEL SEGTOR SALUD
}

\begin{abstract}
SUMARIO: I. Introducción. II. ¿Qué es lo que contribuye a un accidente de trabajo en el sector salud? III. Panorama de la protección de la salud de los trabajadores de salud en México. IV. ¿Cómo se puede lograr una adecuada gestión de riesgos? V. Conclusiones.
\end{abstract}

Alberto Abad SuÁREz Ávila*

\section{INTRODUCGIÓN}

El presente ensayo es resultado de la invitación que mi colega, el doctor José Ma. Serna, gentilmente me extendió para participar en el seminario Regulación de la protección de los trabajadores de la salud, celebrado en mayo de 2016 en el Instituto de Investigaciones Jurídicas de la UNAM.

El tema es importante, y su problemática amerita una investigación más exhaustiva sobre un aspecto principal: la vulnerabilidad de los trabajadores de la salud ante los accidentes laborales que diariamente suceden en laboratorios y hospitales en un contexto de incremento en la prestación de los servicios de salud,

* Investigador del Instituto de Investigaciones Jurídicas de la UNAM. Nivel I del Sistema Nacional de Investigadores y Affiliate Scholar del Center for the US and Mexican Law Houston Law Center. Agradezco a la maestra Ariadna Otaiti Suárez su gentil apoyo en la recopilación de información estadística y bibliográfica para el soporte crítico del artículo. 
Este libro forma parte del acervo de la Biblioteca Jurídica Virtual del Instituto de Investigaciones Jurídicas de la UNAM

tanto públicos como privados. La temática que se abordó en el seminario posibilita visibilizar a los trabajadores de salud no solamente como prestadores de los servicios, sino como sujetos, ellos y ellas, con derecho a la protección de la salud, compatible frente a su responsabilidad en la atención al paciente. $\mathrm{Al}$ personal de salud, por ser precisamente quienes se encuentran encargados de la atención, erróneamente se les observa como inmunes a los riesgos biológicos o patógenos, siendo que el nivel de exposición a riesgos que tienen es alto.

En las próximas líneas se aborda, desde una perspectiva sociojurídica, el tema que nos convocó a la reunión. En principio se describe la problemática que viven los trabajadores de la salud en relación con los riesgos biológicos a los que se ven expuestos en las instituciones hospitalarias o en los laboratorios de investigación biomédica; posteriormente se enumeran cuáles han sido las medidas a nivel internacional para la protección y la prevención frente a dichos riesgos, y se describe la situación que se vive en México, la legislación vigente en la materia y los ejercicios que se han hecho para lograr detectar los riesgos de trabajo y evitar accidentes. Al término se propone una serie de recomendaciones que van encaminadas a lograr una adecuada gestión de bioseguridad, ${ }^{1}$ privilegiando así el derecho a la salud de los trabajadores de este sector como un derecho humano universal.

El objetivo final es evidenciar la necesidad de la promoción del derecho a la protección de la salud de los trabajadores del sector salud en la elaboración de las políticas públicas que se generen en un contexto de incremento en la prestación de los servicios de salud.

1 La gestión de bioseguridad puede definirse como la actividad institucional en la que se visualizan y evalúan los riesgos biológicos y sus consecuencias de manera general y específica para cada tipo de procedimiento. Orozco Medrano, María del Carmen, "Factores que aumentan el estrés y las prácticas preventivas de seguridad", Revista Asociación Mexicana de Bioseguridad, México, noviembre de 2015, p. 25. 
Este libro forma parte del acervo de la Biblioteca Jurídica Virtual del Instituto de Investigaciones Jurídicas de la UNAM

\section{II. ¿QUÉ ES LO QUE GONTRIBUYE A UN ACGIDENTE} DE TRABAJO EN EL SECTOR SALUD?

Los trabajadores de la salud - o personal sanitario- son "todas las personas que llevan a cabo tareas que tienen como principal finalidad promover la salud". ${ }^{2}$ Esta definición incluye a doctores, enfermeras, internistas, enfermeros, camilleros, técnicos de enfermería, investigadores, laboratoristas y personal de intendencia que realizan diversas actividades en distintas áreas hospitalarias y laboratorios de salud.

Las funciones que cada uno realiza significan una exposición constante a riesgos biológicos, definidos como los agentes y materiales potencialmente transmisibles para los humanos, animales y otras formas de vida. ${ }^{3}$ Por lo general, los accidentes de trabajo ${ }^{4}$ que más se reportan son las pinchaduras con agujas hipodérmicas, bisturís u otros instrumentos que involucren el contacto con sangre contaminada de un paciente. También se reporta personal de laboratorio infectado con alguna sustancia o fluido, por un manejo inadecuado de la muestra, o médicos infectados que tienen un primer contacto con el paciente que llega de urgencia y que puede tener alguna enfermedad altamente contagiosa.

Las actividades hospitalarias conllevan riesgos potenciales para la salud. Además, existen múltiples factores que intervienen tanto en la actitud del personal como en la forma de responder ante situaciones críticas, que aumentan la posibilidad de sufrir

2 Organización Mundial de la Salud, "Personal sanitario", disponible en: http://wwwewho.int/topics/health_workforce/es/.

3 Unión General de Trabajadores, Riesgos biológicos: generalidades, Madrid, disponible en: http://wrew.ucm.es/data/cont/docs/3-2013-02-18-2-RIESGO\%20 BIOLOGICO. \%20IDENTIFICACI\%C3\%93N\%20r\%20PREVENCI\%C3\%93N.pdf.

4 Accidente de trabajo es toda lesión orgánica o perturbación funcional, inmediata o posterior, o la muerte, producida repentinamente en ejercicio o con motivo del trabajo, cualesquiera que sean el lugar y el tiempo en que se preste (artículo 474 de la Ley Federal del Trabajo). 
Este libro forma parte del acervo de la Biblioteca Jurídica Virtual del Instituto de Investigaciones Jurídicas de la UNAM

un accidente laboral, o la falta de adherencia a los protocolos de bioseguridad. ${ }^{5}$ En el artículo publicado por los doctores Héctor Nieto y Fernando Tomasina, titulado "La salud de los trabajadores de salud: estrategias e intervenciones" (2006), se describen los factores que componen las Condiciones y Medio Ambiente de Trabajo (CyMAT). ${ }^{6}$ Los autores consideran que el análisis de las condiciones de trabajo en los servicios de salud es complejo y poco considerado en las políticas de gestión de tales servicios. A continuación se presenta una clasificación de éstos:

1. Factores de riesgo vinculados al microclima:

- Ambientales: exposición a temperaturas elevadas con áreas poco ventiladas.

- Ruido: por ejemplo, en el área de urgencias (ruidos de ambulancia, movimiento de personal y hasta gritos o llanto de pacientes).

- Tecnología: proceso de adaptación a nuevas tecnologías, manejo de dispositivos.

2. Factores de riesgo contaminantes. Dentro de los principales riesgos que se identifican en un ambiente laboral, la Organización Mundial de la Salud (OMS) señala los siguientes: ${ }^{7}$

- Físicos: incendios, accidentes eléctricos, explosiones, exposición a radiaciones.

5 El concepto de bioseguridad no tiene una definición como tal en nuestro idioma español, sin embargo, la Organización Mundial de la Salud la define como un conjunto de normas y medidas para proteger la salud del personal frente a riesgos biológicos, químicos y físicos a los que está expuesto en el desempeño de sus funciones, también a los pacientes y al medio ambiente (2005).

6 Nieto, Héctor y Tomasina, Fernando, La salud de los trabajadores de la salud: estrategia e intervenciones, disponible en: https://cursos.campusvirtualsp.org/pluginfile. php/2527/mod_resource/content/1/curso_2009/Modulo_4/m4-lp-estrategias-Nieto Tomasina_borrador_.pdf.

7 Orozco Medrano, María del Carmen, op. cit., p. 25. 
Este libro forma parte del acervo de la Biblioteca Jurídica Virtual del Instituto de Investigaciones Jurídicas de la UNAM

- Químicos: contacto con reactivos biológicos, usos y manipulación del material.

- Biológicos: fluidos corporales, sangre, agentes patógenos. Dentro de los riesgos biológicos en hospitales predomina el problema de la hepatitis $\mathrm{B}$ y $\mathrm{C}$ y el virus de inmunodeficiencia humana (VIH). Estos virus tienen en común formas de transmisión parental y exposición de mucosas de origen accidental. $\mathrm{Al}$ respecto, en el texto $E l$ trabajador de la saludy las enfermedades infecciosas adquiridas se destaca que el virus de la hepatitis $\mathrm{B}(\mathrm{VHB})$ es un agente común en el trabajo hospitalario y el mayor responsable de las infecciones virales para el trabajador de la salud. ${ }^{8}$ Cabe señalar que el mecanismo más frecuente es la exposición accidental parental, siendo la maniobra de encapuchar la aguja una causa muy habitual de accidente.

3. Procesos individuales:

- Problemas familiares, económicos, psicosociales, de personalidad y de salud. Éstos derivan en un estrés negativo que se refleja en distracciones, falta de atención y situaciones psicosomáticas.

4. Factores organizacionales (condiciones de trabajo):

- El esfuerzo físico y psicológico de la tarea impuesta a los trabajadores en las grandes cargas de trabajo (dobles turnos y guardias) e interdependencia de actividades. Es común la sobrecarga de trabajo a los estudiantes residentes a quienes someten a turnos de 36 horas sin posibilidad de descanso. La sobrepoblación de pacientes en hospitales públicos frente a poco personal.

8 Morelos Ramírez, Rubén, "El trabajador de la salud y las enfermedades infecciosas adquiridas", Revista de la Facultad de Medicina de la UNAM, México, núm. 4, 2014, p. 35. 
Este libro forma parte del acervo de la Biblioteca Jurídica Virtual del Instituto de Investigaciones Jurídicas de la UNAM

- La estructura organizacional de la institución, la jerarquización y la asignación de funciones.

- Liderazgo organizacional y estilo administrativo para asignar tareas, fondos y recursos.

5. Falta de estandarización de protocolos que señalen el uso de técnicas o equipos para la protección contra la gran variedad de agentes infecciosos.

6. Desconocimiento de los protocolos de seguridad, o negativa para seguirlos, y falta de capacitación de los trabajadores de salud en el desarrollo de sus funciones:

- El personal de salud suele tener desconocimiento o falta de información sobre los protocolos de seguridad, de prevención o medidas a seguir en caso de algún accidente, o no sabe a qué elementos de riesgo se enfrenta. Mucho se debe al exceso de confianza - "a mí no me va pasar" - que les da el portar una bata blanca, la cual no les da inmunidad a un contagio si no se siguen las reglas específicas.

7. Proceso de comunicación inadecuado entre los profesionales de salud:

- Se rompe el ciclo de comunicación en algún momento. Suele pasar que la supervisora no le informa a su enfermera que el paciente que va a tratar tiene el virus del VIH y no se toman medidas de precaución.

Dada la frecuencia de la concreción de los riesgos de los que se habla en el apartado anterior, a nivel internacional se ha procurado realizar algunas propuestas que ayuden a prevenir accidentes de trabajo ante diversos riesgos, principalmente biológicos. Morelos Ramírez destaca la importancia, por ejemplo, del manual de Clasificación de agentes etiológicos, con base en 
Este libro forma parte del acervo de la Biblioteca Jurídica Virtual del Instituto de Investigaciones Jurídicas de la UNAM

el riesgo ubicación, e informa que a raíz de esta clasificación se publicaron el Manual de bioseguridad en laboratorio (Laboratory Biosafety Manual) de la OMS y el manual de Bioseguridad en laboratorios de microbiología y biomedicina (Biosafety in Microbiological and Biomedical Laboratories) por los Institutos Nacionales de Salud (National Institutes of Health o NIH) en conjunto con el Centro para el Control y Prevención de Enfermedades (Center for Disease Control and Prevention o CDC) de Estados Unidos. ${ }^{9}$ Estos manuales se realizaron con el fin de aplicar diferentes requerimientos en el manejo de las prácticas de laboratorio para la protección del personal del sector salud. Las publicaciones, señala el autor, mencionan la clasificación de diversas cabinas de bioseguridad para la manipulación segura de los agentes infecciosos en el laboratorio, el equipo de protección personal para el trabajo del laboratorio microbiológico y otros temas. La importancia de estas publicaciones es que son el antecedente de la disciplina de la bioseguridad. ${ }^{10}$

\section{PANORAMA DE LA PROTEGGiÓN DE LA SALUD \\ DE LOS TRABAJADORES DE SALUD EN MÉXICO}

En el caso de México se tiene referencia de un estudio publicado en 2009, titulado "Heridas con material punzocortante en un Instituto Nacional de Salud de México", ${ }^{11}$ en el que se registraron los accidentes con material punzocortante entre los trabajadores de salud. El objetivo del estudio era conocer la incidencia de los accidentes con material punzocortante en el Instituto Nacional de Perinatología "Isidro Espinosa de los Reyes" para que a par-

$9 \quad$ Ibidem, p. 36 y 37.

10 Idem.

11 Barroso Aguirre, Javier et al., "Heridas con material punzocortante en un Instituto Nacional de Salud de México", Perinatología y Reproducción Humana, México, vol. 23, núm. 3, julio-septiembre de 2009, p. 141, disponible en: http:// wrw.medigraphic.com/pdfs/inper/ip-2009/ip093c.pdf. 
Este libro forma parte del acervo de la Biblioteca Jurídica Virtual del Instituto de Investigaciones Jurídicas de la UNAM

tir de esos datos se diseñaran estrategias de prevención para los trabajadores de salud que laboran en la institución. ${ }^{12}$ Este es uno de los pocos reportes de los que se tiene registro de una base de datos con accidentes de trabajo en México. El tema preocupa por el descuido o falta de interés que tienen las instituciones de salud por visualizar los accidentes de trabajo del sector.

Los resultados del reporte indican lo siguiente: se registraron 125 accidentes, de los cuales 105 (84\%) corresponden a punciones con aguja u objeto afilado y $20(16 \%)$ a salpicaduras con sangre y/o fluidos corporales. Se presentan 4.3 accidentes por mes. Las enfermeras, estudiantes de enfermería y residentes son los grupos con mayor porcentaje de accidentes; el quirófano y la sala de recuperación, los sitios donde más ocurren, y el emplear instrumentos para sutura, un procedimiento de varias etapas y jeringas con agujas, caracterizan tales accidentes. ${ }^{13}$

A partir del estudio mencionado se han derivado algunos textos que identifican a los trabajadores de salud que están en riesgo:

1) Médicos y cirujanos.

2) Cirujanos dentistas.

3) Paramédicos.

4) Enfermeras.

5) Camilleros.

6) Personal de quirófano.

7) Personal de limpieza y lavandería.

8) Laboratoristas clínicos y de investigación. ${ }^{14}$

Del estudio antes citado y de algunos otros reportes no publicados, se observan problemáticas relacionadas con las condiciones y medio ambiente de trabajo, como por ejemplo, la exposición directa a agentes patógenos:

\footnotetext{
12 Idem.

13 Idem.

14 Morales Ramírez, Rubén, op. cit., p. 38.
} 
Este libro forma parte del acervo de la Biblioteca Jurídica Virtual del Instituto de Investigaciones Jurídicas de la UNAM

- Hasta un $62 \%$ de los accidentes de trabajo ocurren debido a piquetes con agujas en diferentes situaciones (lancetas, bisturís, cortaduras, salpicaduras en piel intacta, cortadura con vidrio, tijeras, con todo tipo de objetos punzocortantes, laminillas, entre otros objetos).

- Los trabajadores tienen mayores riesgos de exposición a hepatitis $\mathrm{B}$, hepatitis $\mathrm{C}$, VIH y a otras infecciones como influenza y ébola.

Asimismo, hay una falta de aplicación de medidas de gestión del riesgo. En efecto, en México hay pocos hospitales que cuentan con un programa de gestión de bioseguridad, entendida como la actividad institucional que visualiza, analiza y evalúa el riesgo biológico de manera general para cada tipo de procedimiento. En el foro Bioseguridad y salud, celebrado a iniciativa de la Sociedad Mexicana de Salud en diciembre del 2015, la enfermera Martha Huertas presentó una ponencia ${ }^{15}$ donde abordó el tema de la problemática de no reportar los accidentes de trabajo por parte de los trabajadores de salud, por motivos diversos, pero sobre todo por el temor a represalias o a perder su trabajo. Además, recordó que en 1987 se inició el Programa de Salud Ocupacional, con el doctor Samuel Ponce de León Rosales, el cual tenía el objetivo de proporcionar un reporte voluntario, y se tuvo una buena respuesta porque se les ofreció un beneficio a los trabajadores. Así, en el estudio se revelaron accidentes reportados e incidencias de infección VIH, hepatitis B y hepatitis C. Y también otro estudio que vale la pena mencionar sobre la salud de los trabajadores de salud es el que lleva por título "Tuberculosis en trabajadores de la salud: importancia de los programas de vigilancia y control". ${ }^{16}$

15 Huertas, Martha, "Bioseguridad hospitalaria. Prevención de riesgos laborales y para el paciente: el caso de jeringas y objetos punzocortantes" (mimeo), en el foro Bioseguridad y salud, celebrado el 8 de diciembre de 2015 en las instalaciones de la Dirección General de Epidemiología de la Secretaría de Salud.

16 Ostrosky-Zeichner, Luis et al., "Tuberculosis en trabajadores de la salud: importancia de los programas de vigilancia y control", Salud Pública en México, 
Este libro forma parte del acervo de la Biblioteca Jurídica Virtual del Instituto de Investigaciones Jurídicas de la UNAM

Pero volviendo a la ponencia de Huertas, ésta refiere que los programas de seguridad, de salud o de bioseguridad en los hospitales generalmente sólo ofrecen el reporte voluntario, y aunque en algunos casos es obligatorio, no se ofrecen vacunas, antirretrovirales ni ningún otro tipo de garantías al trabajador. Además, no se le da un seguimiento adecuado al caso, lo que hace que se desaliente el reporte por parte de los trabajadores. ${ }^{17}$

Muchos accidentes no se reportan, como es el caso de los patólogos, de los cirujanos y de los anestesiólogos. Los cirujanos son la categoría que se llega a accidentar más, pero no reportan porque consideran el "a mí no me va a pasar" o por pensar que si reportan van a perder su plaza. Hay miedo al castigo y existen hospitales en los cuales los cirujanos incluso piensan que si reportan un accidente podrían no darles una base, por creer que manifestar la exposición puede ser tomado como resultado de ser distraído o descuidado, lo que, como mencionamos, acarrearía dificultades para el proceso de basificación. ${ }^{18}$ En voz del personal, "vivimos en una cultura de ocultar información por miedo a represalias, o a perder lo que se tiene (una mentoría, una base, una beca) y no se quiere causar «problemas»" ${ }^{19}$

Este ejemplo permite observar la distancia que existe dentro del sector salud entre el derecho a la protección de la salud y el acceso al mismo por parte de los trabajadores. A los trabajadores del sector salud se les suele observar como inmunes al riesgo. El trabajador tiene la obligación de curar y de devolver la salud al paciente, pero paradójicamente se olvida, en la normatividad y la reglamentación vigentes, que ellos tienen derecho a la protección de su salud y a tener acceso a servicios sanitarios, pues son más vulnerables a sufrir alguna infección o algún contagio. Si no se tiene una conciencia del riesgo y conocimiento claro y reflexi-

México, vol. 42, núm. 1, enero del 2000, pp. 48-52, disponible en: http://wrw. scielosp.org/pdf/spm/v42n1/2399.pdf.

17 Huertas, op. cit.

18 Foro Bioseguridad y salud, diciembre de 2015.

19 Idem. 
Este libro forma parte del acervo de la Biblioteca Jurídica Virtual del Instituto de Investigaciones Jurídicas de la UNAM

vo de éste, lo que sucederá es que los profesionales expuestos a agentes biológicos o químicos tengan la posibilidad de sufrir consecuencias graves a su salud.

Los promotores de políticas de prevención consideran que existe poca conciencia en los trabajadores de la salud, pero sobre todo en las generaciones nuevas, ya que estamos viendo esta actitud generacional de "no me va a pasar nada", "yo puedo hacerlo", aunado a que ahora en algunas escuelas se ha restado el tiempo de práctica para desarrollo de competencias laborales. ${ }^{20}$

Por otro lado, en México hay una falta de obligatoriedad para que el personal médico cuente con inmunización. En contraste, existen ciudades en Estados Unidos en las cuales no se permite ejercer a los profesionales en salud si no cuentan con todo su esquema de vacunación. La inmunización del trabajador significa una barrera protectora para los pacientes y una medida de defensa para el personal sanitario. El Comité Asesor sobre Prácticas de Inmunizaciones (Advisory Committee on Immunization Practices o ACIP) tiene una serie de recomendaciones con relación al uso de agentes inmunizantes para el trabajador de salud que destaca que las inmunizaciones que son más recomendadas por tener un aporte significativo son contra hepatitis B, influenza, sarampión, rubeola o varicela. ${ }^{21}$ En el caso de los hospitales de nuestro país, suele pasar que los internos se nieguen a ser vacunados ante riesgos como el de la influenza estacionaria. El personal que se niega a vacunarse firma su negativa y de esta manera el hospital se libera de cualquier responsabilidad por riesgo de trabajo, sin embargo, el personal queda expuesto a un contagio.

También puede apreciarse una falta de capacitación en el uso de material de riesgo (jeringas, material punzocortante). En México, a los estudiantes de medicina, de enfermería y a los médicos internos de pregrado se les da un curso de poca duración cuando hacen sus prácticas. A menudo los estudiantes refieren

\footnotetext{
20 Idem.

21 Morales Ramírez, Rubén, op. cit, p. 38.
} 
Este libro forma parte del acervo de la Biblioteca Jurídica Virtual del Instituto de Investigaciones Jurídicas de la UNAM

que en la facultad o escuela de medicina nadie les enseña a manejar las agujas ni a tomar muestras con equipo seguro. No tienen capacitación constante en las aulas universitarias ni tienen la suficiente preparación cuando llegan a los centros hospitalarios; aprenden en la práctica real, por lo que se presentan muchos accidentes por su torpeza y falta de habilidades, y genera negligencia médica e irresponsabilidad del sector salud.

Otro problema es la sobrecarga de trabajo del personal de salud. En este aspecto podemos afirmar que si un trabajador tiene que hacer múltiples actividades es más susceptible de sufrir un accidente. Es decir, la sobrecarga de trabajo es un factor muy alto para que condicionen accidentes. Las jornadas de trabajo de las enfermeras, de los internos y médicos, quienes cubren a veces dobles turnos sin descanso, sin días festivos, jornada acumulada en otro hospital, en su práctica privada, hacen perder habilidades debido al agotamiento al que se ven sometidos. Además de tener la presión de los jefes de piso, supervisores y exigencia de los familiares de los pacientes de responderles para salvar vidas y curar enfermedades, resulta que la presión social y profesional está lejos de entender los derechos laborales, y de que el mismo sector salud no los exige ante las autoridades correspondientes.

De igual forma, hay un gran desconocimiento de precauciones estándar. A la fecha hay personas que no saben cuáles son, y en muchas ocasiones las confunden con precauciones universales. Los que más cumplen con estas precauciones son los laboratorios, no obstante, en hospitales o centros de salud, los médicos y enfermeras todavía no las cumplen porque no son punibles o sancionables. En ocasiones tampoco puede el personal distinguir entre los conceptos de prevención y precaución. En este tema, el documento más reciente sobre gestión de riesgos es el publicado en 2015 por la Dirección General de Epidemiología, titulado "Lineamientos para la gestión del riesgo biológico".22

22 https://wrww.gob.mx/cms/uploads/attachment/file/159103/Lineamientos_para _la_gestion_de_riesgo_biologico.pdf. 
Este libro forma parte del acervo de la Biblioteca Jurídica Virtual del Instituto de Investigaciones Jurídicas de la UNAM

Por otro lado, existe otra clase de riesgos; un gran número de reportes de accidentes reportados describe que personal de limpieza, al recoger bolsas de plástico, se han pinchado con jeringas que no se desecharon en el contenedor correspondiente. La NOM087-ECOL-1995 y la NOM-087-SEMARNAT-SSA-20002, de carácter obligatorio, refieren la manera de clasificar y especifican el correcto manejo de los residuos para mantener la salud ambiental y se previene el desecho de los residuos en tiraderos clandestinos que puedan afectar la salud. ${ }^{23}$

Finalmente, en nuestro país hay una falta de equipo de protección personal y de cumplimiento de normatividad en el desecho de residuos peligrosos. En efecto, aunque ahora es más común ver a personal del sector salud empleando gorra, guantes, gafas de protección y botas, falta mucho por hacer y poder conseguir una buena administración de recursos para equipar hospitales y laboratorios a nivel estatal y local.

\section{IV. ¿CÓMO SE PUEDE LOGRAR UNA ADEGUADA GESTIÓN DE RIESGOS?}

Para comenzar a reflexionar sobre el asunto se debe reconocer el problema, para, en conjunto, hacer un esfuerzo a nivel nacional, pues si las instituciones no reconocen o evaden el problema no se puede avanzar. En lo que sigue se retoman propuestas de especialistas en materia de bioseguridad, pero también desde el punto de vista jurídico:

- Establecer normatividad en los programas de gestión de bioseguridad, para la prevención, gestión y seguimiento de riesgos.

- Lograr afinidad para definir medidas adecuadas de bioseguridad, biocustodia y garantizar manejo de agentes biológicos y niveles de seguridad adecuados.

23 Idem. 
Este libro forma parte del acervo de la Biblioteca Jurídica Virtual del Instituto de Investigaciones Jurídicas de la UNAM

- Convencer a las autoridades y generar conciencia en los trabajadores de que deben cuidarse y protegerse, bajo la idea de que tenemos que trabajar en paralelo para poder tener cambios concretos.

- Observar la normatividad universal. En la Declaración de Seúl sobre Seguridad y Salud en el Trabajo ${ }^{24}$ se reconoce que la seguridad y salud en el trabajo es un derecho humano fundamental, tal como se estipula en el artículo 23 de la Declaración Universal de los Derechos Humanos. En el documento se hace un llamamiento para la creación de una cultura de prevención en materia de seguridad y salud, que requiere la participación de todos los miembros de la sociedad.

- Garantizar acciones de prevención de accidentes:

1) Tomar precauciones estándar establecidas en la NOM045.

2) Garantizar a los trabajadores el uso del equipo de protección personal (EPP). Usar el equipo adecuado de acuerdo al nivel de laboratorio - los detalles sobre requerimientos para laboratorios de otros niveles de bioseguridad y su EPP se pueden encontrar en guías y manuales de seguridad internacionales y en la NOM045-.

3) En materia de inmunización es necesario tener un registro de inmunizaciones por trabajador que refleje el expediente médico completo. Los hospitales podrían desarrollar protocolos para el manejo y control de enfermedades que pueden ser prevenidas por vacunas. Salvo en excepciones se debe tener el esquema completo de vacunación obligatorio. Es importante generar esfuerzos nacionales para la elaboración de una nor-

24 Organización Internacional del Trabajo, Declaración de Seúl sobre Seguridad y Salud en el Trabajo, Cumbre de Seguridad y Salud, disponible en: wrw.ilo.org/womsp5/groups/public/@dgreports/@dcomm/documents/statement/woms _095955.pdf. 
Este libro forma parte del acervo de la Biblioteca Jurídica Virtual del Instituto de Investigaciones Jurídicas de la UNAM

ma que establezca la obligatoriedad de que el personal de salud tenga todo su esquema de vacunación, como hepatitis B, influenza, sarampión, parotidis, sarampión, viruela, entre otras enfermedades.

- En materia de acciones para atención de accidentes, éstas deben ofrecer la ventaja de vigilar la frecuencia de accidentes, un sistema que debe estar accesible los 365 días del año, las 24 horas del día.

- En materia de intervención se debe analizar el tipo de accidente, la circunstancia y cómo ocurrió.

- En materia de notificación es necesario concientizar a los trabajadores de la salud de que es indispensable un reporte sobre cualquier incidente, por mínimo que sea, para poder descartar alguna infección o darle la atención inmediata. Este registro o informe de accidentes laborales se debe concentrar en una base de datos que permita tomar medidas de prevención y precaución para evitarlos a futuro.

- En materia de investigación de la fuente y del accidentado, para tener una atención adecuada, al momento de notificar el accidente se debe saber cuál fue la fuente de contagio. Si fue de un paciente se debe tener el expediente clínico; si fue de algún agente biológico se debe saber de cuál se trata. Por otro lado, se debe contar con el expediente actualizado del afectado para tener las medidas necesarias de atención.

- En materia de seguimiento, hay que ofrecerlo, porque si éste no se hace el trabajador puede pensar que es inútil reportar los accidentes si al final no va a hacerse nada para protegerlo. Asimismo, establecer prioridades es muy importante.

- Código de ética para los profesionales de la salud ocupacional. Es importante enfatizar que la responsabilidad es de todos en materia de prevención. El desempeño de los profesionales de la salud ocupacional resulta deter- 
Este libro forma parte del acervo de la Biblioteca Jurídica Virtual del Instituto de Investigaciones Jurídicas de la UNAM

minante en la promoción y protección de la salud de los trabajadores. Éste se debe basar en un código de ética que obligue a la profesionalización y buenas prácticas para garantizar el derecho a la protección de la salud de los trabajadores. Un profesional de riesgo debe ser capaz de identificar necesidades de organización para la implementación de gestión de riesgos adecuado.

De acuerdo a la $\mathrm{OMS}^{25}$ el derecho al "grado máximo de salud que se pueda lograr" exige un conjunto de criterios sociales que propicien la salud de todas las personas, entre ellos la disponibilidad de servicios de salud, condiciones de trabajo seguras, vivienda adecuada y alimentos nutritivos. El derecho a la salud abarca libertades y garantías que incluyen el acceso a un sistema de protección de la salud que ofrezca a todas las personas las mismas oportunidades de disfrutar del nivel máximo de salud que se pueda alcanzar.

Este derecho definido por la OMS tiene que ver con un momento en el cual los derechos de los pacientes y los derechos de los prestadores de servicios de salud se vuelven una realidad ante la obligación de los Estados por hacer efectivos, no ya programáticos, sino efectivos, los derechos contenidos en las constituciones y en los tratados internacionales.

El momento que vive nuestro país abre la posibilidad para que se empiece a reflexionar sobre una serie de temas que tienen que ver tanto con los derechos de los pacientes al recibir los servicios de salud como de los derechos de los prestadores de los servicios de salud al realizar efectivamente esta prestación; es preciso garantizar su protección ante los riesgos de diferente índole a los que se ven expuestos.

La pregunta de fondo es: ¿vamos a asegurar nuestro derecho a la salud contenido en la Constitución y en los tratados internacionales? Hacerlo implicaría una nueva relación, una nueva

25 Organización Mundial de la Salud, "Salud y derechos humanos", disponible en: http://wrww.who.int/mediacentre/factsheets/fs323/es/. 
Este libro forma parte del acervo de la Biblioteca Jurídica Virtual del Instituto de Investigaciones Jurídicas de la UNAM

cobertura entre las prestaciones del servicio desde la visión de proteger al paciente, sin olvidar al prestador del servicio, al profesional médico y de la salud.

\section{Gonclusiones}

Ahora es el momento de reflexionar acerca de nuestra normatividad, reglamentos, normas y códigos de buenas prácticas. Plantearse cuáles requieren ponerse al día y qué nos va a exigir si el acceso a la salud se convierte finalmente en ese derecho que vamos a gozar y que vamos a garantizar a todos los mexicanos. Se deben garantizar las condiciones suficientes de salud, de protección a la seguridad tanto de los usuarios como de los prestadores de servicios. Es necesario comenzar con una cultura de bioseguridad que debe promoverse desde las aulas y reafirmarse en los centros de trabajo. El costo-beneficio de la prevención es mucho mayor a las consecuencias de algún trabajador afectado que genera incapacidad, costos de tratamiento, indemnización o demanda laboral.

Además, se requiere de un trabajo reflexivo donde estemos dispuestos a modificar la normatividad para alcanzar un paradigma de prestación de servicios adecuado que nos proteja a todas las partes involucradas (pacientes y personal de salud). Es un reto importante para que haya un diálogo entre autoridades y organismos de salubridad para actualizar los derechos de los trabajadores y así encauzar su protección en nuestro sistema de salud.

En México, actualmente contamos con personal más capacitado, con más ambiciones académicas y de investigación en materia de bioseguridad. Tal es el caso de la Asociación Mexicana de Bioseguridad A. C. y la Dirección General de Epidemiología, perteneciente a la Secretaría de Salud. Es importante un nexo académico con los comités de ética, bioética o de bioseguridad para realizar estudios interdisciplinarios y avances en la materia. 
Este libro forma parte del acervo de la Biblioteca Jurídica Virtual del Instituto de Investigaciones Jurídicas de la UNAM

\title{
REGULACIÓN DE LA PROTEGGIÓN DE LOS TRABAJADORES DE LA SALUD EN MÉXICO
}

\author{
Roxana TRejo GonZÁLEZ*
}

\begin{abstract}
SUMARIO: I. Introducción: relevancia de la normativa nacional. II. Normativa internacional para la protección de los trabajadores de la salud. III. Reflexión final.
\end{abstract}

\section{INTRODUCGIÓN: RELEVANCIA}

DE LA NORMATIVA NACIONAL

Desarrollaré en las siguientes líneas mi reflexión sobre el tema de la regulación relativa a la protección de los trabajadores de la salud. No soy experta en leyes, soy médica de profesión, pero sí me gustan las leyes porque hacen algo. Las herramientas normativas nos impulsan a las instituciones para tener mejores sistemas en cuestión de recursos, y en muchas ocasiones, en cuestión de procesos. Para nosotros es importante contar con regulaciones como las que existen en la Constitución, la Ley Orgánica de la Administración Pública Federal, la Ley Federal del Trabajo y el Reglamento Federal de Seguridad y Salud en el Trabajo, así como otras normas oficiales en la materia y ordenamientos que tienen que ver con la seguridad y salud en el trabajo. Yo he trabajado en un

* Gerente corporativo de Epidemiología y Control de Infecciones del Centro Médico The American British Cowdray, I. A. P., profesora en la Universidad Anáhuac y presidenta de la Asociación Mexicana del Estudio de las Infecciones Nosocomiales, S. G. (AMEIN). Este texto es producto de la versión estenográfica editada por personal del Instituto de Investigaciones Jurídicas de la UNAM. 
Este libro forma parte del acervo de la Biblioteca Jurídica Virtual del Instituto de Investigaciones Jurídicas de la UNAM

hospital público y ahora trabajo en un hospital privado, por lo que tengo las dos visiones. Tengo muchos años de experiencia en el Hospital General "Dr. Manuel Gea González", fui secretaria de seguridad durante todo ese tiempo en la Comisión de Seguridad e Higiene y ahora laboro en una institución privada. En las dos instituciones tomamos la ley en sus términos y la aplicamos como tal de acuerdo a como está escrita.

También existe un artículo, 123, apartado A, fracción XV, de nuestra ley suprema, según la cual el patrón tiene que contar con todo lo necesario para evitar los riesgos de accidentes en cuestión de manejo de maquinaria y equipamiento que sus empleados puedan estar utilizando. Y está lo dispuesto por la Ley Federal del Trabajo, en su artículo 132, fracción XVI, que también se refiere al deber de los patrones de contar con todo lo necesario para evitar los riesgos de accidentes en el centro de trabajo.

Por otro lado, las normas mexicanas que emite la Secretaría del Trabajo y Previsión Social determinan las condiciones mínimas necesarias que deben existir en esta materia, lo cual, considero, constituye un gran avance, pues a través de los años nos ha hecho contar con mejor equipamiento y mejores condiciones. Asimismo, la Comisión Nacional de Higiene lo que plantea es contar con ciertas condiciones de seguridad en los lugares o centros de trabajo y prevenir los actos inseguros que nos ponen en riesgo, dependiendo mucho de varias circunstancias, como pueden ser equipo de protección, capacitación o educación.

En relación con las normas oficiales mexicanas, existen 41 normas sobre seguridad, en actividades como transporte, trabajos de altura, electricidad e instalaciones, entre otras.

Otro bloque normativo que debo mencionar es el de las normas de salud referentes a contaminantes con sustancias químicas, ruido, radiaciones, presiones ambientales anormales, condiciones térmicas, vibración e iluminación. En los hospitales también tenemos pacientes que pueden recibir radioterapia, y debemos apegarnos a esta normativa, como también debe seguirse en consultorios dentales, con la finalidad de dar cumplimiento y en caso 
Este libro forma parte del acervo de la Biblioteca Jurídica Virtual del Instituto de Investigaciones Jurídicas de la UNAM

de tener revisiones por la Comisión Federal de Protección contra Riesgos Sanitarios (Cofepris), evitar ser sancionado.

Otro bloque normativo al que debo referirme son las normas de organización que tienen que ver con equipo de protección personal muy enfocado no a la parte de salud, sino a la parte relacionada con equipamiento y mantenimiento, así como con la identificación de peligro y riesgo de sustancias químicas. Hay que mencionar también que las comisiones de seguridad e higiene son una herramienta importante para nuestras instituciones, sean privadas o públicas.

\section{NORMATIVA INTERNAGIONAL PARA LA PROTEGGIÓN DE LOS TRABAJADORES DE LA SALUD}

A nivel mundial, enfocados en regulaciones o recomendaciones de instituciones como la Organización Mundial de la Salud (OMS), se ha dicho que, por ejemplo, la Guía de la OMS sobre el uso de jeringuillas con mecanismos de seguridad, de 2015, está muy enfocada en el tema del manejo de jeringas. Por cierto, en México no tenemos estadísticas con relación al uso adecuado de la inyección en la terapia médica, el uso exclusivo de una sola aguja para un solo vial, o bien, sobre el uso de jeringas seguras.

La guía de la OMS busca propiciar el empleo de jeringas inteligentes, las cuales cuentan con dispositivos de seguridad que al terminarse de usar se disparan, cerrando o protegiendo el elemento punzocortante. También impulsa el que no se reúsen las jeringas, aunado a la prevención de accidentes por jeringas punzocortantes. Es muy amplia esta guía y muy interesante, y en su parte estadística informa que de 2 a 3 millones de accidentes por año se dan a través de instrumentos punzocortantes, los cuales derivan en infecciones de hepatitis $\mathrm{B}$, hepatitis $\mathrm{C}$ y de virus de inmunodeficiencia humana (VIH).

Este tipo de accidentes, y las infecciones que generan, son de gran impacto y representan un problema importante, tanto 
Este libro forma parte del acervo de la Biblioteca Jurídica Virtual del Instituto de Investigaciones Jurídicas de la UNAM

económico como personal, para la persona que los sufre. Aun así, no tenemos una estadística real en nuestro país sobre esta clase de accidentes; hay estudios, hay trabajos en los hospitales, pero no tenemos conformada una verdadera estadística sobre el tema. No sabemos realmente, como país, qué ocurre. Se requiere tener datos y estadísticas para poder aterrizar e implementar medidas de prevención. Creo que hay que trabajar mucho porque no hay manera de regular si no contamos con esta información.

¿Qué más recomienda la OMS? Recomienda que utilicemos una nueva tecnología en las agujas, que usemos la ingeniería nueva que nos puede ayudar a prevenir accidentes, y también nos habla de no reutilizar las agujas. El objetivo de esta guía es propiciar prácticas seguras para reducir a cero este tipo de riesgos, para pacientes y profesionales de la salud.

En la Unión Europea se ha trabajado muy fuerte en esta temática. En sus regulaciones se tocan puntos como la parte preventiva o de educación, pero también la parte de equipamiento, de la necesidad de tener los datos y estadísticas pertinentes y de cómo analizarlos, así como la parte de gestión de riesgos y qué hacer con esa información. Creo yo que es muy valioso todo lo que ha sucedido en la Unión Europea.

En nuestro país existen normas enfocadas a la disminución del riesgo, como puede ser la NOM-045, que prevé precauciones ante el riesgo de que te salpique, te caiga algún fluido biológico, o te pinches dentro de un procedimiento médico. Pero hay que considerar que no solamente con las agujas de jeringas se pueden generar accidentes y lesiones. En realidad, existen infinidad de dispositivos médicos que nos pueden poner en riesgo en las instituciones de salud. Los accidentes se pueden presentar cuando se sutura, cuando se hacen cortes; en los laboratorios - hablando de hepatólogos - y en las áreas de investigación de muchos hospitales en los cuales también se manejan instrumentos para hacer investigación en animales.

La normativa actual dispone que el responsable sanitario del establecimiento hospitalario, el director, debe implementar un 
Este libro forma parte del acervo de la Biblioteca Jurídica Virtual del Instituto de Investigaciones Jurídicas de la UNAM

sistema de notificación y seguimiento de incidentes, accidentes con objetos cortantes y punzantes y debe garantizar que se apliquen las medidas profilácticas correspondientes de acuerdo a la reglamentación aplicable a cada establecimiento para la atención médica. Debemos contar con un sistema interno; que cada área de salud cuente con un sistema interior, un programa, un protocolo en donde la notificación sea esencial. Lo valioso de la notificación, aparte de tener un número para efecto de control y seguimiento, es intervenir en cuestión profiláctica para VIH.

Es importante decir que en el país existen regulaciones que se debieran aplicar, pero que muchas no se aplican por falta de insumos o por falta de conocimiento. Sin embargo, creo que, al final, esta normativa nos ayuda a mejorar nuestros procesos internos y el riesgo disminuye. Así, por ejemplo, también existe una norma (087) relativa al manejo de residuos peligrosos biológico-infecciosos que tuvo un cambio hace algunos años. En esta norma hay todo un sistema, un buen sistema de proceso; si esa norma no la aplicas y te llegan a supervisar, te cierran el lugar o te sancionan.

Esta norma de residuos peligrosos biológico-infecciosos también tiene que ver con el traslado de los residuos: ¿cómo manejarlos?, ¿cómo disponer de ellos en el área de salud? Cuando yo aplico una inyección con una jeringa debo saber en qué lugar tengo que disponer de esa jeringa y cómo la tengo que disponer. Todo esto es relevante para la prevención de riesgos de accidentes.

\section{REFLEXIÓN FINAL}

Esta normativa que hemos descrito nos ayuda a mejorar, pero hay que considerar que en México hay instituciones que tienen la tecnología nueva para brindar mayor seguridad y otras que carecen de ella. No obstante, sí debemos recalcar la importancia de que existan equipos que nos ayuden a disminuir el riesgo; equipos de seguridad que en el mismo momento que se terminen de usar se puedan 
Este libro forma parte del acervo de la Biblioteca Jurídica Virtual del Instituto de Investigaciones Jurídicas de la UNAM

obstruir - teniendo en cuenta que aun así no hay seguridad total, porque hay que tener todo un contexto alrededor-.

Creo yo que en la parte de regulación tenemos bastantes normas, pero nos falta todavía lograr más. Nos falta asegurar que podamos contar con lo mínimo indispensable en cuestión de tecnología para que de verdad cerremos el círculo, además de tener programas efectivos de educación en temas de salud y regulaciones internas. Los insumos, como el equipo de protección personal o las nuevas tecnologías, tienen que estar unidos, con capacitaciones enfocadas a sus usos y con la finalidad de evitar el riesgo, con competencias específicas y seguimientos puntuales. Si hay esas competencias, nunca va a suceder nada.

Las regulaciones nos sirven para contar con lo necesario, con lo mínimo indispensable, porque al final, si no contamos con esta regulación, es muy complicado tener lo esencial para poder prevenir riesgos. El riego va a estar siempre presente; siempre va a haber pacientes, siempre va a haber gente con hepatitis B, hepatitis $\mathrm{C}$ o con $\mathrm{VIH}$, pero necesitamos avanzar más rápido en cuestión de regulación, e impulsar que exista, como la NOM087, una regulación enfocada específicamente al riesgo de accidentes por punzocortantes y salpicaduras dentro de las áreas de atención de la salud. Creo que hay que tener algo contextual enfocado a este tipo de riesgo.

Es prioritario contar con políticas públicas que impulsen la calidad y la seguridad de los trabajadores de la salud; el solo enfoque a los pacientes deja coartada esta gran labor. 
Regulación de la protección de los trabajadores de la salud para la prevención del riesgo biológico, editado por el Instituto de Investigaciones Jurídicas de la UNAM y Becton Dickinson de México, se terminó de imprimir el 30 de julio de 2018 en los talleres de Impresora Gráfica Hernández, S. A. de C. V., Cordobanes 369, colonia Evolución, 57700 Ciudad Nezahualcóyotl, Estado de México, tel. 6424 5388. Se utilizó tipo Baskerville en 9, 10 y 11 puntos. En esta edición se empleó papel book cream de 60 gramos para los interiores y cartulina couché de 250 gramos para los forros. Consta de 1,000 ejemplares (impresión offset). 